\title{
REPARACIÓN COLECTIVA
}

ESTUDIO DE CASO DE LA RED NACIONAL DE INICIATIVAS CIUDADANAS POR LA PAZ Y CONTRA LA GUERRA "REDEPAZ"

IVÁN MAURICIO LUNA NAVARRO

UNIVERSIDAD SANTO TOMÁS

FACULTAD DE DERECHO

MAESTRÍA EN DEFENSA DE LOS DERECHOS HUMANOS Y EL DIH ANTE ORGANISMOS, TRIBUNALES Y CORTES INTERNACIONALES

BOGOTÁ D.C 


\section{REPARACIÓN COLECTIVA}

ESTUDIO DE CASO DE LA RED NACIONAL DE INICIATIVAS CIUDADANAS

POR LA PAZ Y CONTRA LA GUERRA "REDEPAZ"

\section{IVÁN MAURICIO LUNA NAVARRO}

Trabajo de grado para optar al título de Maestría en Defensa de los Derechos Humanos y el DIH ante Organismos, Tribunales y Cortes Internacionales

Directora de tesis

ANA MARÍA JIMÉNEZ

UNIVERSIDAD SANTO TOMÁS

FACULTAD DE DERECHO

MAESTRÍA EN DEFENSA DE LOS DERECHOS HUMANOS Y EL DIH ANTE ORGANISMOS, TRIBUNALES Y CORTES INTERNACIONALES

BOGOTÁ D.C 
Nota de Aceptación

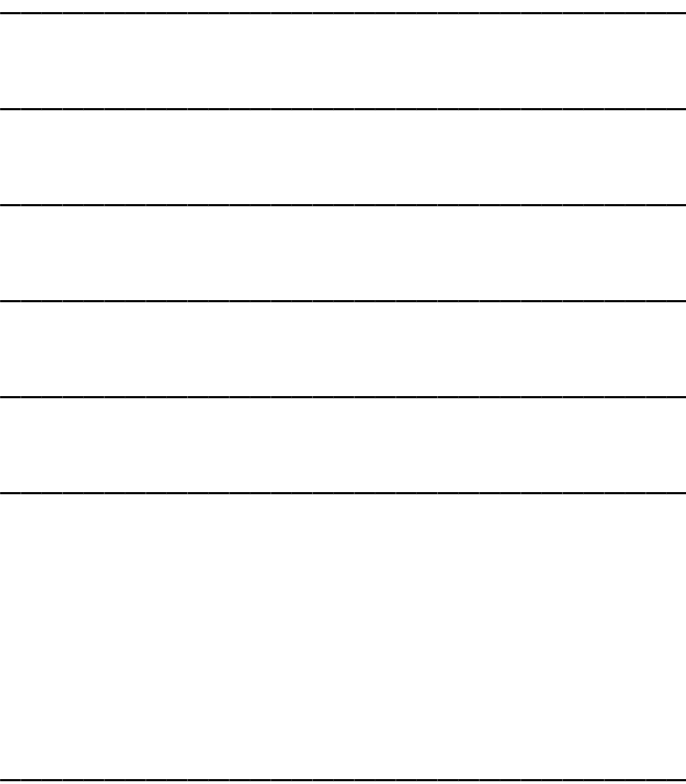

Presidente del Jurado

\begin{tabular}{l}
\hline Jurado \\
\hline Jurado
\end{tabular}

Bogotá D.C., 30 de mayo de 2018 


\section{Contenido}

pág.

$\begin{array}{ll}\text { Introducción } & 1\end{array}$

$\begin{array}{ll}\text { 1. Objetivos } & 6\end{array}$

1.1 Objetivo general 6

$\begin{array}{ll}1.2 \text { Objetivos específicos } & 6\end{array}$

2. Marco teórico y conceptual $\quad 7$

$\begin{array}{ll}\text { 3. Metodología } & 17\end{array}$

4. Estándares sobre el Derecho a la Reparación 18

4.1 Estándares Internacionales sobre el Derecho a la Reparación $\quad 18$

4.1.1 Origen del derecho a la reparación en el ámbito del derecho internacional 18

4.1.2 La Resolución 60/147 del 16 de diciembre de 2005

4.1.3. El sistema interamericano de derechos humanos 28

4.1.4 Reparación colectiva en el ámbito internacional 37

4.1.5 Experiencias internacionales de reparación colectiva $\quad 40$

4.2 Estándares Nacionales sobre el Derecho a la Reparación $\quad 44$

4.2.1 La reparación colectiva en la ley 1448 
5. Caracterización de la Red de Iniciativas Ciudadanas por la Paz y contra la Guerra REDEPAZ

5.1 Contexto

5.2 La Red de Iniciativas Ciudadanas por la Paz y en Contra de la Guerra REDEPAZ 65

5.3 Redepaz como Sujeto Nacional de Reparación Colectiva 71

5.4 El Proceso de Reparación Colectiva de REDEPAZ 75

5.4.1 Fase de acercamiento 75

5.4.2 Fase de registro 79

5.4.3 Alistamiento

5.4.4 Diagnóstico del daño

5.4.5 Fase Formulación y aprobación del Plan de Reparación Colectiva

5.5 Análisis de la Oferta, Invitación y/o Demanda de la Reparación Colectiva

6. Medidas de Reparación Colectiva establecidas en el Plan Integral de Reparación Colectiva de REDEPAZ

6.1 Fundamentos conceptuales, éticos y políticos de la Reparación Colectiva de REDEPAZ

6.2.1 Fortalecimiento organizativo: para hacerse efectiva se adoptaron las siguientes acciones 


\section{Lista de Figuras}

Figura 1. Tipos de Colectivos Corte IDH

$\begin{array}{ll}\text { Figura 2. Concepto de Víctima } & 50\end{array}$

Figura 3. Ruta de Reparación Colectiva $\quad 56$

$\begin{array}{ll}\text { Figura 4. Estructura Funcional de REDEPAZ } & 71\end{array}$

Figura 5. Estructura organizacional de REDEPAZ 72 


\section{Introducción}

Colombia atraviesa uno de los momentos más importantes de su historia como resultado del Acuerdo de Paz alcanzado entre el Gobierno nacional con las Fuerzas Armadas Revolucionarias de Colombia - Ejército del Pueblo (FARC-EP). Además, por la instauración de las mesas de negociación con el Ejército de Libración Nacional (ELN). Los diálogos de paz en Colombia se inician en los años noventa con la desmovilización, reincorporación, reintegración e inclusión social y política de algunos grupos beligerantes que han intervenido en el conflicto armado interno del país, tales como el Ejército Popular de Libración (EPL), el Movimiento 19 de abril (M-19), Movimiento Armado Quintín Lame, el Partido Revolucionario de los Trabajadores (PRT), la Corriente de Renovación Socialista (CRS), Autodefensas Unidas de Colombia (AUC)y las Fuerzas Armadas Revolucionarias de Colombia - Ejército del Pueblo (FARC-EP).

Los retos de la sociedad y del Estado son múltiples: garantizar en forma sostenida el monopolio de la fuerza legítima del Estado y la presencia de la institucionalidad en todos los territorios; la inclusión social y política de grupos desmovilizados; el fortalecimiento del tejido social en los territorios impactados por el conflicto armado interno; la reconciliación de los diversos actores que participaron en la guerra; el goce efectivo de los derechos humanos (el derecho de las víctimas y de la sociedad en su conjunto a la verdad, justicia, reparación y no repetición), y el derecho al desarrollo.

El proceso de inclusión jurídica de estos grupos a la sociedad ha incluido nuevos marcos 
normativos tanto a nivel nacional como a nivel internacional, diferenciados y adoptados por el Estado colombiano ${ }^{1}$. Esto se cumple especialmente, aunque no exclusivamente, por la prohibición de las amnistías e indultos en el derecho internacional y por la posibilidad de los Estados de adoptar procesos de la denominada justicia transicional en el tránsito de la guerra a la paz y de la dictadura a la democracia, así como el pleno respeto por parte de los actores del conflicto de los derechos de las víctimas a la verdad, la justicia, la reparación y la no repetición.

Después de décadas de lucha contra la impunidad a nivel internacional, se logró en los años noventa que se reconociera y adoptara tratados internacionales que imponen obligaciones a los Estados para aplicar justicia y garantizar los derechos de las víctimas de las graves violaciones e infracciones ocasionadas.

A partir de este momento, los desarrollos del derecho internacional limitan la concesión de amnistías al excluir de este beneficio a los responsables directos de las graves violaciones a los derechos humanos e infracciones del Derecho Internacional Humanitario (DIH), igualmente prohíbe las autoamnistías desde los Estados, de tal suerte que si no se respeta dichos marcos normativos pueden actuar la jurisdicción internacional desde tribunales de cualquier país (jurisdicción universal) y la Corte Penal Internacional (CPI).

Igualmente, organismos internacionales de protección de derechos humanos como la Corte Interamericana de Derechos Humanos a partir del desarrollo de su jurisprudencia han ampliado los estándares de protección de las víctimas. En Colombia, la Constitución de 1991 reconoció la

\footnotetext{
${ }^{1}$ Es necesario indicar que los procesos de paz de los noventa, la desmovilización de los grupos paramilitares y el proceso de negociación con las FARC-EP se realizaron bajo estándares internacionales y constitucionales diferenciados.
} 
prevalencia de los tratados internacionales de derechos humanos sobre el derecho interno con el denominado "Bloque de Constitucionalidad", en tal sentido, todas las medidas legislativas que se adopten estarán sujetas a dichas obligaciones internacionales vigentes de derechos humanos y derecho humanitario.

El presente trabajo se centra en el análisis de este último aspecto, la justicia transicional, en lo relativo al derecho a la reparación de las víctimas del conflicto armado interno, en particular de los grupos paramilitares en el marco del proceso de desmovilización.

Dada la complejidad que implica hoy efectuar análisis o estudios de investigación sobre la reparación de las víctimas de un conflicto armado interno de más de cincuenta años y más de siete millones de víctimas, se ha escogido como tema de investigación el caso específico de la Red Nacional de Iniciativas Ciudadanas por la Paz y Contra la Guerra (REDEPAZ), en su condición de sujeto nacional de reparación colectiva.

Entre las medidas adoptadas por el Estado colombiano dentro del proceso de justicia transicional, operado en la desmovilización de los grupos paramilitares, está la adopción del marco jurídico normado en las Ley 975 del 2005, conocida como Ley de Justicia y Paz, y la Ley 1448 del 2011, denominada Ley de Víctimas y de Restitución de Tierras, con el propósito de garantizar el derecho de las víctimas del conflicto a la reparación integral y a la estricta aplicación de los estándares internacionales en la materia, procedimiento complejo que implicó el concurso de las tres ramas del poder público. 
La pregunta de investigación consiste en: ¿Cuál es el estado actual de las medidas de reparación colectiva de la Red de Iniciativas Ciudadanas para la Paz y en Contra de la Guerra REDEPAZ?

El documento está estructurado en siete capítulos: el primero, delimita los objetivos de la investigación; el segundo, desarrolla el marco teórico y conceptual; el tercero, expone el marco metodológico.

El cuarto, desarrolla el conjunto de dispositivos socio-jurídicos relativos a la reparación colectiva, lo que implica un análisis de los marcos normativos nacionales e internacionales en materia de derecho a la reparación integral y colectiva.

El quinto capítulo, establece el contexto en el que se desarrolla la reparación colectiva y la caracterización del sujeto nacional de reparación colectiva REDEPAZ, teniendo en cuenta que se trata de una organización estructurada en forma de red y con presencia municipal, regional y nacional.

El sexto capítulo, analiza las diferentes medidas de reparación colectiva a favor de REDEPAZ, teniendo en cuenta las características propias de la organización y los daños ocasionados por el conflicto armado interno.

Por último, el séptimo capítulo, plantea unas conclusiones y recomendaciones que contribuyen al goce efectivo de los derechos de las personas que son parte de la organización y 
de esta como estructura jurídica y política. 


\section{Objetivos}

\subsection{Objetivo general}

Establecer el estado actual de la reparación colectiva de Red de Iniciativas Ciudadanas para la Paz y en Contra de la Guerra - REDEPAZ, como sujeto nacional de reparación colectiva.

\subsection{Objetivos específicos}

- Identificar el marco normativo nacional e internacional aplicado a la reparación colectiva en el caso específico.

- Caracterizar a REDEPAZ como sujeto nacional de reparación colectiva en el marco normativo señalado.

- Establecer las medidas adoptadas para la reparación colectiva de la REDEPAZ.

- Establecer las recomendaciones correspondientes, de acuerdo con los hallazgos y las conclusiones. 


\section{Marco teórico y conceptual}

Para el desarrollo de la investigación se toma como marco teórico los siguientes conceptos:

Derechos humanos. Conjunto de atributos, principios y prerrogativas, de aceptación universal, orientados a asegurar al ser humano su dignidad como persona, en su dimensión individual, social, material y espiritual. Son derechos reconocidos constitucionalmente y garantizados jurídicamente por el Estado. Su realización efectiva y permanente resulta indispensable para el desarrollo integral del individuo por un proyecto de vida digna para todos y todas.

Son prerrogativas que, de acuerdo con el derecho internacional y nacional, tiene la persona frente al Estado para impedir que este interfiera en el ejercicio de ciertos derechos fundamentales, o para obtener del Estado la satisfacción de ciertas necesidades básicas y que son inherentes a todo ser humano por el mero hecho de ser humano (Rodríguez, 2007, p.12).

El objetivo de los derechos es proteger la dignidad humana imponiendo a los Estados obligaciones negativas y positivas (Naciones Unidas, 2014). Hay tratados que buscan incorporar las obligaciones de los Estado con respecto a los derechos económicos, sociales y culturales de las personas y vincularlas con la justicia transicional. En cuanto a estos derechos, el Pacto Internacional de Derechos Económicos, Sociales y Culturales, de 1966, indica que

cada uno de los Estados partes...se compromete a adoptar medidas, tanto por separado como mediante la asistencia y la cooperación internacionales, especialmente económicas y 
técnicas, hasta el máximo de los recursos de que disponga, para lograr progresivamente por todos los medios apropiados, inclusive en particular la adopción de medidas legislativas, la plena efectividad de los derechos...reconocidos (citado en Naciones Unidas, 2014, p. 11).

En este sentido, la evaluación del cumplimiento de un Estado de sus obligaciones con respecto a los derechos económicos, sociales y culturales se da por medio de las medidas adoptadas "en función de los recursos, financieros o de otro tipo, de que dispone" (Naciones Unidas, 2014, p. 12).

Deber de reparar. Es un principio del Derecho Internacional de los Derechos Humanos (DIDH) relativo a que todo hecho ilícito de un Estado debe ser juzgado y reparado.

Como señala el Comité Internacional de la Cruz Roja (CICR), "es norma del DIH consuetudinario que un Estado responsable de violaciones de DIH, en concreto de violaciones graves de DIH, tenga la obligación de reparar de manera íntegra la pérdida o la lesión causada" Henckaerts \& Doswald (como se citó en Pérez-León, 2008, p. 16).

Estas violaciones van en contra de las obligaciones definidas en el Pacto Internacional de Derechos Económicos, Sociales y Culturales, las cuales se establecen en tres niveles: 1) los Estados deben abstenerse de interferir en el disfrute de los derechos, 2) los Estados deben impedir que terceros interfieran en el disfrute de los derechos y 3) los Estados deben adoptar medidas apropiadas para la plena realización de los derechos (Naciones Unidas, 2014). Para la protección de estos derechos, se requiere "que se establezcan mecanismos accesibles, transparentes y eficaces de rendición de cuentas' de manera que sea posible supervisar el cumplimiento y ofrecer reparación por las violaciones" (p. 15). 
Reparación. En su concepción etimológica, el vocablo reparación proviene del latín reparať̌o - ōnis, que según el Diccionario de la Real Academia de la lengua española significa (a) acción y efecto de reparar cosas mal hechas o estropeadas y (b) desagravio, que alude a la satisfacción completa de una ofensa daño o injuria. La Real Academia de la Lengua define la reparación como el efecto de un daño u ofensa causada.

Por su parte, la Organización de Naciones Unida (ONU)propone:

"La reparación debe en toda la medida de lo posible hacer desaparecer las consecuencias del hecho ilícito y establecer la situación que con toda probabilidad no habría existido de no haberse cometido el hecho" (Crawford, 1928, p. 47).

"El Sistema Interamericano de Derechos Humanos (SIDH), a través de las sentencias de la Corte IDH, manifiesta que el término reparación consiste en las medidas que tienden a hacer desaparecer los efectos de las violaciones cometidas. Su naturaleza y su monto dependen del daño ocasionado en los planos tanto material como inmaterial". Corte IDH (como se citó en Pérez-León, 2008, p. 9).

En el ámbito del DIDH y, específicamente, de la jurisprudencia de la Corte Interamericana de Derechos Humanos (Corte IDH), la reparación se refiere a las medidas a través de las cuales se pretende hacer desaparecer de manera procedente, los efectos de las violaciones cometidas. El tipo de reparación (ya sea material o moral) están determinadas por el daño ocasionado y en relación directa con las violaciones de derechos humanos cometidos (Vargas, 2006; Cesti, 2001; 
Suárez, 1999).

Para la Corte Interamericana de Derechos Humanos, la reparación no solo constituye el restablecimiento de la situación anterior a la violación de derechos humanos, sino que también implica remediar cualquier situación que hubiera ido en contra de las normas internacionales de derechos humanos (Naciones Unidas, 2014).

El Estatuto de la Corte Penal Internacional (CPI) incluye en su marco normativo la participación $^{2}$ de las víctimas en el esclarecimiento de los hechos y su derecho a ser reparadas ${ }^{3}$, así como la persecución de los perpetradores, por lo que se constituye en parte sustancial en la lucha contra la impunidad.

Entre las diferentes medidas de reparación posibles, se incluye la reforma institucional. Esta, más allá de la simple reparación, busca que haya garantías de no repetición, es decir, que en el futuro no se vuelvan a cometer violaciones de derechos humanos. Para que esto se cumpla, es necesario, no solo cambiar la estructura del Estado, sino también repercutir en las causas que dieron lugar a la violación de estos derechos y, de esta forma, llegar a ser "integral" (Naciones Unidas, 2014, p. 51).

\footnotetext{
${ }^{2}$ El derecho a la participación de las víctimas en los procedimientos de la Corte es el principal de los derechos otorgados por el Estatuto, su base se encuentra en el artículo 68 (3) que establece lo siguiente: "La Corte permitirá, en las fases del juicio que considere conveniente, que se presenten y tengan en cuenta las opiniones y observaciones de las víctimas si se vieren afectados sus intereses personales y de una manera que no redunde en detrimento de los derechos del acusado o de un juicio justo e imparcial ni sea incompatible con éstos. Los representantes legales de las víctimas podrán presentar dichas opiniones y observaciones cuando la Corte lo considere conveniente y de conformidad con las Reglas de Procedimiento y Prueba". (Corte Penal Internacional, 1998, p.36).

${ }^{3}$ La base de este derecho se encuentra contemplada en el artículo 75 del Estatuto de Roma.
} 
Justicia transicional. Alude al deber de la sociedad en respuesta a violaciones graves a la dignidad humana, producto de conflictos armados o dictaduras. El objetivo es reconocer tanto las violaciones como a las víctimas para promover iniciativas de paz y justicia; sin embargo, esta puede bien decidirse por castigar a los responsables o bien ofrecer indultos o amnistías para favorecer la reconciliación.

La justicia transicional se fundamenta en cuatro principios: 1) la obligación del Estado de investigar a los presuntos autores de violaciones graves de los derechos humanos y del derecho internacional humanitario (DIH); 2) el derecho a conocer la verdad sobre los abusos del pasado y la suerte que han corrido las personas desaparecidas; 3) el derecho de las víctimas de violaciones graves de derechos humanos y del DIH a obtener reparación y 4) la obligación del Estado de impedir, mediante la adopción de distintas medidas, que tales atrocidades vuelvan a producirse en el futuro (Naciones Unidas, 2014). Entre las medidas de la justicia transicional para cumplir con estos principios, se incluyen los mecanismos de búsqueda de la verdad, mecanismos judiciales y mecanismos de reparación y de reforma institucional.

Desde el derecho, existen cuatro teorías que explican diversos enfoques de la justicia transicional:

1. La maximalista. "Propone una visión restrictiva del juzgamiento de la responsabilidad, a través de la imposición de castigos severos en los tribunales o cortes. Los defensores de esta teoría plantean que mediante la persecución penal se disuade a futuros perpetradores de actos 
violentos, se establece y legitima el Estado de Derecho y se fortalece la democracia" Olsen (como se citó en Fundación Ideas para la Paz, 2014, p. 13). Esta teoría rechaza medidas alternativas que impliquen perdón y olvido, como las amnistías totales.

2. La minimalista. "Plantea que los tribunales, lejos de tener un efecto disuasorio, exacerban la violencia y la inestabilidad, por lo que medidas como las amnistías son más útiles. Se parte aquí del hecho de que la transición enfrenta un sin número de obstáculos como los spoilers y que cualquier medida orientada a juzgar responsabilidades de manera muy rápida contribuye a la aparición de saboteadores". Las amnistías son justificables para reducir o bloquear futuras injusticias. Olsen (como se citó en Fundación Ideas para la Paz, 2014, p. 13).

3. La moderada. "Parte del reconocimiento de que tanto los maximalistas como los minimalistas consideran que las comisiones de verdad es la segunda mejor opción para enfrentar los abusos del pasado". Olsen (como se citó en Fundación Ideas para la Paz, 2014, p. 13).

4. La holística. "Rechaza los enfoques anteriores por considerar que reducen la defensa y protección de los derechos humanos a un acervo de instituciones y herramientas para lidiar con los abusos del pasado. Según este enfoque, medidas e instrumentos aislados no son idóneos para enfrentar con éxito todos los problemas que los gobiernos y las sociedades tienen que abordar durante las transiciones". Olsen (como se citó en Fundación Ideas para la Paz, 2014, p. 13).

Por su parte, De Greiff, (2008) concibe "las políticas de justicia transicional como aquellas medidas que se implementan para responder a los legados de las violaciones masivas de derechos 
humanos que suelen ocurrir bajo condiciones de conflicto o bajo regímenes autoritarios. Estas políticas suelen incluir, por lo menos, los siguientes elementos: medidas de justicia penal, de esclarecimiento histórico, reparación a las víctimas y reformas institucionales, incluida la depuración". De Greiff (como se citó en Rubiano, 2010, p. 182).

Para Arango (2007), la justicia transicional presupone una reducción de las pretensiones distributivas y compensatorias de la justicia de los sectores excluidos a los beneficios sociales, es decir, que la aceptación de algún grado de impunidad y el aplazamiento de la realización de las garantías sociales se justifica por el goce pleno del derecho a la Paz. Arango (como se citó en Rubiano, 2010, p. 182).

En este sentido, Martín (2007), argumenta:

Enfocar entonces la justicia transicional desde una perspectiva de derechos integrales, donde se consideren los civiles y políticos, conjuntamente con los económicos, sociales y culturales, permitiría definir estrategias para la concreción de su principal objetivo: construir democracias sólidas que eviten en el futuro las violaciones a los derechos humanos Martín (como se citó en Rubiano, 2010, p. 182).

Ospina, (2007), manifiesta que "el tema de la justicia transicional es otra cara de la política de derechos humanos. No es un tema de justicia ligada a los códigos, es un tema eminentemente político y así hay que asumirlo”. (p. 153). 
El Sistema de las Naciones Unidas ha definido la Justicia Transicional como "toda la variedad de procesos y mecanismos asociados con los intentos de una sociedad por resolver los problemas derivados de un pasado de abusos a gran escala, a fin de que los responsables rindan cuentas de sus actos, servir a la justicia y lograr la reconciliación" (Naciones Unidas, 2014, p.45).

Uno de los principios de las normas internacional de derechos en los cuales se basa la justicia transicional es el derecho de las víctimas de violaciones graves de derechos humanos y del derecho internacional humanitario a obtener reparación, la cual también constituye uno de los mecanismos de la justicia transicional.

Es de notar que, aunque los mecanismos de justicia transicional son necesarios y capaces de repercutir duraderamente en una sociedad, no se deben formar expectativas excesivas acerca de su potencial. Incluso cuando las violaciones de derechos humanos se aborden en un marco de justicia transicional y su proceso sea exitoso, ello no garantiza el goce general y efectivo de esos derechos (Naciones Unidas, 2014).

Marco de justicia y paz. De acuerdo a las Leyes 975 de 2005 y 1448 de 2011, se entiende por sistema de justicia y paz como el marco jurídico creado para facilitar los procesos de paz y la reincorporación a la vida civil de los miembros de grupos armados al margen de la ley que se hayan desmovilizado individual o colectivamente. Dentro de este marco, se garantiza los derechos de las víctimas a la verdad, la justicia y la reparación integral. 
Reparación colectiva. Se concibe la reparación colectiva como el reconocimiento y la dignificación de los grupos, las comunidades o las organizaciones sociales y políticas, que han sufrido un daño colectivo.

Este daño colectivo se refiere a la afectación negativa en el contexto social, comunitario o cultural que, a causa del conflicto armado interno, sufren las comunidades, grupos u organizaciones. (Ministerio del Interior, 2016).

La Ley 1448 de 2011, en su artículo 25, comprende las siguientes medidas de reparación integral: "restitución, indemnización, rehabilitación, satisfacción y garantías de no repetición, en sus dimensiones individual, colectiva, material, moral y simbólica. Cada una de estas medidas será implementada a favor de la víctima, dependiendo de la vulneración de sus derechos y las características del hecho victimizante”. (Ley 1448 de 2011).

La reparación se concibe como una de las medidas de la justicia transicional para abordar las violaciones graves de derechos humanos. Es decir, hace parte de las obligaciones de los Estados para la protección de estos derechos. Sin embargo, se considera que, sin que haya una reforma institucional enfocada hacia garantías de no repetición, la reparación no altera de manera sustancial la situación estructural en la cual se cometieron las violaciones (Naciones Unidas, 2014, p. 65). Por ello, la reparación debe ser vista como una medida y no como la meta en la protección de derechos humanos.

Víctima. Se define como "víctima a toda persona que haya sufrido daños, individual o 
colectivamente, incluidas lesiones físicas o mentales, sufrimiento emocional, pérdidas económicas o menoscabo sustancial de sus derechos fundamentales, como consecuencia de acciones u omisiones que constituyan una violación manifiesta de las normas internacionales de derechos humanos o una violación grave del derecho internacional humanitario"4.

Con base en las anteriores definiciones, se puede afirmar que, en la medida en que la reparación colectiva busca reconocer y dignificar a las víctimas que han sufrido un daño colectivo con respecto a sus derechos humanos, los Estados tienen el deber de responder, por medio de la justicia transicional y las medidas de reparación y reforma institucional, a las violaciones graves a la dignidad humana y promover la paz y la justicia, para asimismo garantizar que se cumpla el deber de reparar.

${ }^{4}$ Numeral V. Conjunto de principios y directrices básicos sobre el derecho de las víctimas de violaciones manifiestas de las normas internacionales de derechos humanos y de violaciones graves del derecho internacional humanitario a interponer recursos y obtener reparaciones. 60/147 Resolución aprobada por la Asamblea General de las Naciones Unidas el 16 de diciembre de 2005 


\section{Metodología}

La investigación se soporta en una metodología descriptiva y exploratoria, cuyo método de análisis responde a la hermenéutica jurídica. El objeto de investigación es un estudio de caso de REDEPAZ, al considerar sus prácticas, trayectoria e impacto generado durante los últimos años, como entidad comprometida con la paz.

Las técnicas de recolección de datos son el procesamiento, sistematización y análisis de información de fuentes primarias y secundarias a través de entrevistas a los miembros de la organización, la recopilación de información documental de fuentes directas de la organización y

otras fuentes gubernamentales. Adicionalmente, se recurre a solicitudes de información, vía derecho de petición a la Unidad Nacional de Víctimas entidad competente en el asunto objeto de investigación.

La investigación se desarrolla tomando como marco temporal el período comprendido entre el 11 de marzo de 2015, fecha en que se firmó al plan Integral de reparación Colectiva entre REDEPAZ y la Unidad para la Atención y Reparación Integral a las Víctimas, y el 11 de marzo de 2018. 


\section{Estándares sobre el Derecho a la Reparación}

En el presente capítulo, se aborda el marco normativo nacional e internacional sobre el derecho a la reparación y se explica el "Bloque de Constitucionalidad" que acoge Colombia en términos de derechos humanos.

\subsection{Estándares Internacionales sobre el Derecho a la Reparación}

\subsubsection{Origen del derecho a la reparación en el ámbito del derecho internacional}

Para abordar el proceso de reparación colectiva de las víctimas del conflicto armado en Colombia, es necesario analizar su reglamentación en el contexto internacional, los organismos multilaterales competentes dentro del proceso normativo internacional, la base jurídica para el derecho a recurso y la reparación de las víctimas o el abuso de poder en algunos países de la comunidad internacional.

Comprender la reparación en el ámbito del derecho internacional, demanda remontarse al origen de los derechos humanos y al derecho consuetudinario. Al respecto la Corte Permanente de Justicia Internacional (CPJI), órgano jurisdiccional de la Sociedad de las Naciones, declaró en 1928 que: "Es un principio de derecho internacional, e incluso un concepto general del derecho, que cualquier incumplimiento de un compromiso entraña la obligación de efectuar una reparación”. CPJI (como se citó en Nuñez \& Zuluaga, 2012, p. 209). 
En 1934, este mismo tribunal, mediante el voto razonado del Juez Schuking exaltó la doctrina de las normas de ius cogens, las cuales consisten en respetar las normas de derecho imperativo o perentorio sin alterar ni excluir ninguna parte de su contenido, si esto llegase a pasar se declararía nulo. Estas normas son de jerarquía superior, ya que amparan los intereses colectivos fundamentales.

En 1948, la Corte Internacional de Justicia (CIJ)emite un pronunciamiento sobre los conceptos de reparación y las normas de ius cogens para establecer la reparación en casos de violaciones a derechos y principios fundamentales.

Para 1963, la CIJ estableció las obligaciones erga omnes ("respecto a todos" o "frente a todos") procedentes de las normas de ius cogens para referirse a la aplicación general de las normas. (Nuñez \& Zuluaga, 2012). Este conjunto de decisiones contribuyó con la adopción del artículo 53 de la Convención de Viena sobre el Derecho de los Tratados"”.

Desde 1948, la Asamblea General de las Naciones Unidas estableció la Comisión de Derecho Internacional (CDI) y le otorgó la responsabilidad de reglamentar las responsabilidades del Estado. Entre 1969 y 1980, se aprobó 35 artículos base para estudiar la responsabilidad del Estado en hechos ilícitos. Finalmente, la Asamblea General de las Naciones Unidas del 28 de enero de 2002, en su Quincuagésimo Sexto periodo de sesiones aprobó la Resolución 56/83 sobre la Responsabilidad de los Estados por Hechos Internacionalmente Ilícitos. (Crawford,

\footnotetext{
${ }^{5}$ Artículo 53. "... una norma imperativa de derecho internacional general es una norma aceptada y reconocida por la comunidad internacional de Estados en su conjunto, como norma que no admite acuerdo en contrario y que solo puede ser modificada por una norma ulterior de derecho internacional general que tenga el mismo carácter”. El Derecho de los Tratados (como se citó en Nuñez \& Zuluaga, 2012, p. 210).
} 
2009).

Esta Resolución evidencia en el primer capítulo de su segunda parte:

las consecuencias de la comisión de un hecho internacionalmente ilícito: ese hecho no afecta la continuidad del deber del Estado responsable de cumplir la obligación violada (artículo 29): si el hecho continúa, el Estado responsable tiene la obligación de ponerle fin (artículo 30, párrafo a) y, si las circunstancias así lo exigen, también es responsable de ofrecer seguridades y garantías adecuadas de no repetición (artículo 30, párrafo b). Además, el hecho internacionalmente ilícito trae aparejado para el Estado responsable, la obligación de reparar íntegramente el perjuicio causado (artículo 31). (Crawford, 2009, p. 5).

De conformidad con lo dispuesto en el artículo 31, el Estado responsable por la comisión de un hecho internacionalmente ilícito, está obligado a reparar íntegramente el perjuicio causado por ese hecho. El "perjuicio" está definido como todo daño, tanto material como moral, causado por el hecho.”. (Crawford, 2009, p. 6).

Por su parte, el movimiento internacional de los Derechos Humanos se inició, con la aprobación el 10 de diciembre de 1948, como un ideal común por el que todos los pueblos y naciones deben esforzarse. Con el propósito de resaltar los derechos civiles, políticos, económicos, sociales y culturales básicos de los que todos los seres humanos deben gozar. 
A lo largo de los años, la Declaración Universal de los Derechos Humanos ha sido aceptada ampliamente como las normas fundamentales de los derechos humanos que los Estados miembros de la ONU deben respetar y proteger. La Declaración Universal, junto con el Pacto Internacional de Derechos Civiles y Políticos y sus dos protocolos facultativos y el Pacto Internacional de Derechos Económicos, Sociales y Culturales, conforman la llamada "Carta Internacional de Derechos Humanos", la cual constituye el referente más importante del derecho internacional en este campo.

La lucha contra la impunidad y el derecho de las víctimas para obtener reparaciones por violaciones a los derechos humanos se cristalizaron en 2005 mediante la aprobación y divulgación de dos grupos de principios: (a) el "Conjunto de principios actualizado para la protección y la promoción de los derechos humanos mediante la lucha contra la impunidad" (en adelante, Principios Internacionales Sobre la Lucha Contra la Impunidad); y (b) los "Principios y directrices básicos sobre el derecho de las víctimas de violaciones manifiestas de las normas internacionales de derechos humanos y de violaciones graves del derecho internacional humanitario a interponer recursos y obtener reparaciones"6 (en adelante, Principios Internacionales Sobre el Derecho de las Víctimas a Obtener Reparaciones).

\subsubsection{La Resolución 60/147 del 16 de diciembre de 2005}

En 1998 las Naciones Unidas encargó a Theo van Boven - experto independiente sobre el derecho de restitución, indemnización y rehabilitación de víctimas de flagrantes violaciones de

\footnotetext{
${ }^{6}$ Aprobados por la Asamblea General de la ONU, AG Res. 60/147 del 16 de diciembre de 2005.
} 
derechos humanos y libertades fundamentales -, el desarrollo de un conjunto de criterios "para reparar graves violaciones de estos derechos”. (Nuñez \& Zuluaga, 2012, p. 211).

Estas pautas fueron promulgadas en una resolución de la Asamblea General de las Naciones Unidas en el año 2000, como los Principios y directrices básicos sobre el derecho de las víctimas de violaciones manifiestas de las normas internacionales de derechos humanos y de violaciones graves del derecho internacional humanitario a interponer recursos y obtener reparaciones". CIJ CPJI (como se citó en Nuñez \& Zuluaga, 2012, p. 211).

La reparación comprenderá "medidas de restitución, indemnización, rehabilitación, satisfacción y garantías de no repetición” (ley 1448 de 2011), según lo establece el derecho internacional, así como el acceso a los procedimientos internacionales y regionales aplicables.

Según el Conjunto de Principios para la protección y promoción de los derechos humanos mediante la lucha contra la impunidad, Principio 31: toda víctima debe tener la posibilidad de ejercer un recurso accesible, rápido y eficaz, por la vía penal, civil, administrativa o disciplinaria", (como se citó en Sentencia C-370/06), incluidas las restricciones a la prescripción. En el ejercicio de dicho recurso, debe beneficiarse de una protección contra actos de intimidación y represalias.

Las reparaciones deben: desarrollarse mediante programas basados en medidas legislativas o administrativas, ser financiadas por fuentes nacionales o internacionales, y dirigidas a individuos y a comunidades. Las víctimas y otros sectores de la sociedad civil deben desempeñar un papel 
significativo en la elaboración y aplicación de tales programas y garantizar la no discriminación.

Los procedimientos especiales de reparación serán objeto de la más amplia publicidad posible, incluso a través de los medios de comunicación privados. Se deberá garantizar y asegurar esa difusión tanto en el interior del país como en el extranjero, incluso por la vía consular, especialmente en los países donde hayan debido exiliarse muchas víctimas.

Los Estados deben establecer mecanismos eficaces para la ejecución de las sentencias que obliguen a reparar daños, conforme al derecho interno y al derecho internacional. Teniendo en cuenta las circunstancias de cada caso, se debería proveer a las víctimas, de forma apropiada y proporcional a la gravedad de la violación y a las circunstancias de cada caso, una reparación plena y efectiva.

De conformidad con el conjunto de principios, las medidas de reparación son:

1. La restitución, siempre que sea posible, ha de regresar a la víctima a la situación anterior a la violación manifiesta de los derechos humanos y del derecho internacional humanitario. Son medidas de restitución el restablecimiento de la libertad, el disfrute de los derechos humanos, la identidad, la vida familiar, la ciudadanía y el regreso a su lugar de residencia, la reintegración laboral y la devolución de sus bienes.

2. La indemnización ha de concederse en forma apropiada y proporcional a la gravedad de la violación y a las circunstancias de cada caso; por todos los perjuicios económicamente 
evaluables que sean consecuencia de violaciones manifiestas de las normas de derechos humanos y del DIH. La indemnización comprende: el daño físico o mental; la pérdida de oportunidades, en particular las de empleo, educación y prestaciones sociales; los daños materiales y la pérdida de ingresos, incluido el lucro cesante; los perjuicios morales y los gastos de asistencia jurídica o de expertos, medicamentos y servicios médicos, psicológicos y sociales.

3. La satisfacción, cuando sea pertinente y procedente, ha de incluir la totalidad o parte de las medidas siguientes: medidas eficaces para conseguir que no continúen las violaciones; verificación de los hechos y revelación pública y completa de la verdad; búsqueda de las personas desaparecidas y de las identidades de los niños secuestrados, entre otras.

4. La satisfacción también ha de incluir, cuando sea pertinente y procedente, la totalidad o parte de las medidas siguientes: una declaración oficial o una decisión judicial que restablezca la dignidad, la reputación y los derechos de la víctima y de las personas vinculadas estrechamente a ella; una disculpa pública que incluya el reconocimiento de los hechos y la aceptación de responsabilidades; la aplicación de sanciones judiciales o administrativas a los responsables de las violaciones; conmemoraciones y homenajes a las víctimas; y una precisa exposición de las violaciones ocurridas en la enseñanza de las normas de derechos humanos y del Derecho Internacional Humanitario, así como en el material didáctico a todos los niveles.

5. Medidas de no repetición que entre otras incluyen, disposiciones adecuadas para que las víctimas no puedan volver a ser objeto de violación de sus derechos. Con ese fin, los Estados deben emprender reformas institucionales y otras normas ineludibles para asegurar el respeto del 
imperio de la ley, promover y mantener una cultura de respeto de los derechos humanos y restaurar o establecer la confianza pública en las instituciones gubernamentales.

Ahora bien, si se tiene en cuenta que, en muchos países, como consecuencia de conflictos armados internos la violencia y la violación de derechos humanos persisten dictaduras y gobiernos antidemocráticos, ha surgido todo un marco normativo de reparación colectiva a las víctimas con fundamento en el derecho a la verdad, la justicia, la reparación y la no repetición.

Según Amnistía Internacional, en la Resolución 60/ 147: "los principios y directrices no entrañan obligaciones nuevas para los Estados, ni derechos nuevos para los ciudadanos, sino más bien métodos y medios más eficaces para el cumplimiento de aquellos y la práctica de estos". (Amnistía Internacional, 2016, p.25). En torno a la reparación del sufrimiento de las víctimas, la Resolución plantea: "la comunidad internacional hace honor a su palabra respecto del sufrimiento de las víctimas, los supervivientes y las generaciones futuras, y reafirma los principios jurídicos internacionales de responsabilidad, justicia y Estado de derecho". Resolución 60/147 (como se citó en Amnistía Internacional 2016, p.25).

Para comprender la integralidad del derecho a la reparación, se hace necesario considerar los aportes realizados por Joinet (1997), citado en Newman Pont (2009):

No se trata sólo del derecho individual que toda víctima o sus familiares tienen a saber lo que ocurrió, que es el derecho a la verdad. El derecho a saber es también un derecho colectivo que hunde sus raíces en la historia, para evitar que puedan reproducirse en el 
futuro las violaciones (Newman Pont, 2009, p. 42).

Según el Informe de Diane Orentlicher, experta independiente encargada de actualizar el conjunto de principios para la lucha contra la impunidad, los principios generales del Derecho a saber son:

El derecho inalienable a la verdad: "Cada pueblo tiene el derecho inalienable a conocer la verdad sobre los acontecimientos sucedidos en el pasado en relación con la perpetración de crímenes aberrantes y de las circunstancias y los motivos que llevaron, mediante violaciones masivas o sistemáticas, a la perpetración de esos crímenes. El ejercicio pleno y efectivo del derecho a la verdad proporciona una salvaguardia fundamental contra la repetición de tales violaciones". (Naciones Unidas, 2005, p.7).

El deber de recordar: "El conocimiento por un pueblo de la historia de su opresión forma parte de su patrimonio y, por ello, se debe conservar adoptando medidas adecuadas en aras del deber de recordar que incumbe al Estado para preservar los archivos y otras pruebas relativas a violaciones de los derechos humanos y el derecho humanitario y para facilitar el conocimiento de tales violaciones. Esas medidas deben estar encaminadas a preservar del olvido la memoria colectiva y, en particular, evitar que surjan tesis revisionistas y negacionistas". (Naciones Unidas, 2005, p.7).

El derecho de las víctimas a saber: "Independientemente de las acciones que puedan 
entablar ante la justicia, las víctimas y sus familias tienen el derecho imprescriptible a conocer la verdad acerca de las circunstancias en que se cometieron las violaciones y, en caso de fallecimiento o desaparición, acerca de la suerte que corrió la víctima”. (Naciones Unidas, 2005, p.7).

Garantías para hacer efectivo el derecho a saber:" Incumbe a los Estados adoptar las medidas adecuadas, incluidas las medidas necesarias para garantizar el funcionamiento independiente y eficaz del poder judicial, para hacer efectivo el derecho a saber. Las medidas apropiadas para asegurar ese derecho pueden incluir procesos no judiciales que complementen la función del poder judicial. Las sociedades que han experimentado crímenes odiosos perpetrados en forma masiva o sistemática pueden beneficiarse en particular con la creación de una comisión de la verdad u otra comisión de investigación con objeto de establecer los hechos relativos a esas violaciones de manera de cerciorarse de la verdad e impedir la desaparición de pruebas. Sea que un Estado establezca o no un Órgano de ese tipo, debe garantizar la preservación de los archivos relativos a las violaciones de los derechos humanos y el derecho humanitario y la posibilidad de consultarlos". (Naciones Unidas, 2005, p.7-8).

Cada país tiene la obligación primordial de respetar, asegurar que se respeten y aplicar "las normas internacionales de Derechos Humanos y Derecho Humanitario. El Estado debe garantizar el derecho de las víctimas a la justicia, en sus tres elementos fundamentales: el acceso igual y efectivo a la justicia; la reparación adecuada, efectiva y rápida del daño sufrido; y el acceso a información pertinente sobre las violaciones y los mecanismos de reparación” (Valencia, 2008, p. 11). 
En este sentido, "las obligaciones asumidas por los países que hacen parte de la comunidad internacional de las Naciones Unidas, en virtud del Derecho Internacional de los Derechos Humanos y del Derecho Humanitario, entrañan consecuencias jurídicas, no solo con respecto a otros Estados, sino también a individuos o grupos de personas subordinados a la jurisdicción de un Estado. La integración de los derechos humanos en la responsabilidad del Estado ha originado la premisa básica de que, en los casos de infracción de obligaciones internacionales, no sólo se debe el resarcimiento y reparación a los Estados, sino también a las personas o grupos perjudicados" (Oficina del Alto Comisionado para las Naciones Unidas para los Derechos Humanos, 2008, p. 5).

\subsubsection{El sistema interamericano de derechos humanos}

El Sistema Interamericano de Derechos Humanos es un conjunto de instrumentos, órganos y mecanismos de supervisión creados en el seno de la Organización de Estados Americanos, cuya función principal es velar por el respeto, la protección y garantía de los derechos humanos en el continente americano. Surge como respuesta a las graves y sistemáticas violaciones de derechos ${ }^{7}$ que ocurrieron a lo largo del continente por parte de los Estados de la región y cuyo origen tuvo lugar en los movimientos de derechos humanos del Cono sur, Brasil, Argentina, Chile, Perú hasta alcanzar toda la región.

El sistema se estructura y consolida a partir de la voluntad de los distintos países del

\footnotetext{
${ }^{7}$ Un sinfín de luchas civiles y guerras, golpes militares y dictaduras, asolaron durante décadas al continente prácticamente en su totalidad.
} 
hemisferio, de contar con un conjunto de instrumentos garantes de los derechos de las personas bajo su jurisdicción, la creación de unos mecanismos de supervisión de dichos instrumentos con la creación de la Comisión ${ }^{8}$ y de la Corte $\mathrm{IDH}^{9}$, y los ingentes esfuerzos de la sociedad civil para asegurar que los Estados y las instituciones creadas cumplan con los fines y objetivos propuestos en tales instrumentos.

La CIDH es un organismo de naturaleza cuasi jurisdiccional, cuya función principal es promover la observancia y la defensa de los derechos humanos en el hemisferio". Mientras que la Corte Interamericana de Derechos Humanos (Corte IDH) “es un órgano de carácter judicial, el cual, en función de su competencia contenciosa, le corresponde determinar la responsabilidad internacional de los Estados, mediante la aplicación e interpretación de la Convención Americana de Derechos Humanos y demás instrumentos interamericanos.

En el marco de sus funciones ante la Comisión, toda persona, grupo de personas u organización no gubernamental puede presentar peticiones o quejas sobre violaciones a los derechos consagrados en la Convención Americana sobre Derechos Humanos o en otros instrumentos interamericanos aplicables, con el objetivo de establecer la responsabilidad internacional del Estado por dichas violaciones. Si la Comisión establece la responsabilidad del Estado, eventualmente el caso puede ser sometido por dicho organismo al conocimiento de la Corte IDH.

\footnotetext{
${ }^{8}$ La CIDH es un órgano principal y autónomo de la Organización de los Estados Americanos (OEA) encargado de la promoción y protección de los derechos humanos en el continente americano. Está integrada por siete miembros independientes que se desempeñan en forma personal y tiene su sede en Washington, D.C. Fue creada por la OEA en 1959

${ }^{9}$ El 22 de mayo de 1979 los Estados Partes en la Convención Americana eligieron, durante el séptimo período extraordinario de sesiones de la Asamblea General de la OEA, a los juristas que, en su capacidad personal, serían los primeros jueces que compondrían la Corte Interamericana. La primera reunión de la Corte se celebró el 29 y 30 de junio de 1979 en la sede de la OEA en Washington, D.C.
} 
Dentro de la protección de los derechos humanos, es fundamental el papel que la víctima o el individuo desempeña en el proceso y las posibilidades de reparación o restitución de las que podría beneficiarse, una vez probada la violación en su contra.

Es importante indicar que los derechos humanos son la piedra angular del derecho internacional, así como del derecho constitucional, es decir, la norma básica que rige las sociedades democráticas y cuyo sustento son los derechos humanos, por lo que deben ser considerados objeto de especial protección. También, estos derechos protegen bienes esenciales como la vida o el libre desarrollo de la personalidad y, en consecuencia, su violación constituye un hecho de especial relevancia. Por tanto, es imperativo evolucionar en los sistemas de derechos humanos hasta llegar a configurar procesos rápidos, sencillos y efectivos de protección de los mismos, donde no se prolongue la espera a una protección, que por su naturaleza no da lugar a la espera (López y Acosta, 2009).

El marco jurídico de protección de los derechos humanos en el sistema interamericano surge de la propia carta fundacional de la organización de los Estados Americanos. El sistema Interamericano ha emitido un conjunto de tratados dentro de los cuales se destaca la Convención Americana sobre Derechos Humanos o "Pacto de San José de Costa Rica", adoptada en la Conferencia Interamericana Especializada sobre Derechos Humanos, realizada en San José, Costa Rica (1969).

En tal sentido, la Convención Americana sobre Derechos Humanos (1969) establece en el 
preámbulo que: "con el propósito de [los estados americanos] de consolidar en este continente, dentro del cuadro de las instituciones democráticas, un régimen de libertad personal y de justicia social. Fundado en el respeto de los derechos esenciales del hombre". (p.1). Con el firme convencimiento de que "sólo puede realizarse el ideal del ser humano libre, exento de temor y de la miseria, si se crean condiciones que permitan a cada persona gozar de sus derechos económicos, sociales y culturales, tanto como de sus derechos civiles y políticos". ${ }^{10}$ (Convensión Americana de Derechos Humanos , 1978, p.44).

El Pacto establece en su primera parte los "deberes de los Estados y los derechos protegidos"; en su segunda parte los "medios de protección" y supervisión de las obligaciones convencionales; y en su tercera parte las disposiciones generales entre otros, la firma, ratificación y enmienda de la Convención.

En sus primeros dos artículos fueron consagradas las tres principales obligaciones internacionales que los Estados asumen al ratificar este tratado: respetar los derechos y libertades reconocidos en ella; garantizar el libre y pleno ejercicio a toda persona sujeta a su jurisdicción; y adoptar las disposiciones de derecho interno para hacer efectivos tales derechos y libertades.

La Convención define cuáles son los derechos protegidos: civiles y políticos (entre otros, derecho a la vida, libertad personal, integridad personal, garantías judiciales, libertad de pensamiento y expresión y el derecho de circulación y residencia). Una única disposición sobre los derechos económicos, sociales y culturales, mediante la cual los Estados partes se

\footnotetext{
${ }^{10}$ Convención Americana sobre Derechos Humanos. Firmada en San José de Costa Rica el 22 de noviembre de 1969. Incorpora a la legislación nacional mediante la Ley 16 de 1972. p.1. San José de Costa Rica 1969.
} 
comprometen a adoptar "providencias [...] para lograr progresivamente la plena efectividad de los derechos que se derivan de las normas económicas, sociales y sobre educación, ciencia y cultura". contenidas en la Carta de la OEA.

La Convención Americana de Derechos Humanos, en su artículo 63.2, establece que cuando la Corte IDH resuelva que hubo una violación de un derecho o libertad protegidos en esta Convención, dispondrá, si ello fuera procedente, que se reparen las consecuencias de la medida o situación que ha configurado la vulneración de esos derechos y el pago de una justa indemnización a la parte lesionada.

La Convención Americana de Derechos Humanos establece a la Corte Interamericana un conjunto de funciones, "la principal es la relativa al examen de casos y emisión de sentencias en las que se declara la responsabilidad internacional de los Estados parte, que hayan ratificado la competencia contenciosa de la Corte. Bajo dicha función se generan los criterios y estándares que dotan de contenido los derechos comprendidos en la Convención y los instrumentos que forman parte del Sistema Interamericano". (Muro, 2013, p.1). El artículo 63.1 de la Convención señala que cuando la Corte decida que hubo violación de un derecho o libertad protegidos en esta Convención, esta dispondrá la reparación al lesionado.

La Corte IDH en relación con la reparación integral ha sostenido que:

(...) el artículo 63.1 de la Convención Americana refleja una norma consuetudinaria que constituye uno de los principios fundamentales del Derecho Internacional contemporáneo sobre la responsabilidad de los Estados. De esta manera, al producirse un hecho ilícito 
imputable a un Estado, surge de inmediato la responsabilidad internacional de este por la violación de la norma internacional de que se trata, con el consecuente deber de reparación y de hacer cesar las consecuencias de la violación ${ }^{11}$. Dicha responsabilidad internacional es distinta a la responsabilidad en el derecho interno ${ }^{12}$ (Corte Interamericana de Derechos Humanos, 2006, p. 138).

La Corte IDH, en el caso de los 19 comerciantes contra Colombia, consideró que esta norma refleja una medida consuetudinaria que forma uno de los principios fundamentales del derecho internacional sobre la responsabilidad internacional de los Estados. La Corte IDH ha adoptado los estándares internacionales en reparación integral, tales como, la restitución, indemnización por daño material e inmaterial, medidas de satisfacción y garantías de no repetición. Señaló el tribunal internacional que "ésta es una obligación internacional a la plena restitución, restitutio in integrum, que consiste en restablecer la situación anterior a la violación o, de no ser posible, en establecer un conjunto de medidas que además de garantizar el respeto por los derechos violados, se reparan las consecuencias producidas por las infracciones y se pague una indemnización como compensación de los daños ocasionados" (caso de la Masacre de Mapiripán contra Colombia, 2005).

A través de su jurisprudencia, la Corte ha logrado establecer una serie de criterios básicos y generales para otorgar las reparaciones integrales, que se pueden sintetizar así:

11 Cfr. Caso Vargas Areco, supra nota 3, párr. 64 y 140; Caso Almonacid Arellano y otros, supra nota 15, párr. 135; y Caso Goiburú y otros, supra nota 5, párr. 141.

12 Cfr. Caso Servellón García y otros, supra nota 3, párr. 161; Caso Ximenes Lopes, supra nota 3, párr. 208; y Caso de las Masacres de Ituango, supra nota 7, párr. 365. 
1. La reparación del daño ocasionado implica, siempre que sea posible, la plena restitución, o restitutio in integrum, que consiste en el restablecimiento de la situación anterior a la violación.

2. De no ser posible, la Corte puede determinar una serie de disposiciones para que, además de garantizar el respeto de los derechos conculcados, se reparen las consecuencias producidas por las infracciones y se establezca, inter alia, el pago de una indemnización como compensación por los daños ocasionados.

3. La obligación de reparar, que está regulada en todos los aspectos (alcance, naturaleza, modalidades y determinación de los beneficiarios) por el derecho internacional, no puede ser modificada o incumplida por el Estado obligado, invocando disposiciones de su derecho interno.

4. La naturaleza y el monto de las reparaciones dependen del daño ocasionado en los planos material e inmaterial. Por tanto, no pueden implicar ni enriquecimiento, ni empobrecimiento para la víctima o sus sucesores López y Acosta (como se citó en Nuñez \& Zuluaga, 2012, p. 215).

La Corte Interamericana de Derechos Humanos estipula los métodos de reparación según la lesión producida: material, inmaterial, patrimonial familiar, al proyecto de vida y a otras formas de reparación traducidas en medidas de satisfacción y garantías de no repetición. A continuación, se hará referencia a estos tipos de reparación según el daño que les da origen.

El daño material se refiere a "la pérdida o detrimento de los ingresos de las víctimas, los 
gastos efectuados con motivo de los hechos y las consecuencias de carácter pecuniario causadas por los hechos del caso sub judice (...)"13. Para la Corte IDH, este tipo de daño está relacionado con los efectos patrimoniales que derivan de la violación y el perjuicio por el lucro perdido. Este daño no tiene otro origen que las consecuencias que derivan directamente de las violaciones cometidas.

El daño material por regla general "atiende todo lo relacionado con el patrimonio y tiene un nexo causal directo con el hecho ilícito. Entre los daños reconocidos por la Corte IDH se encuentran el daño emergente, el lucro cesante y el daño patrimonial, este último considerado de manera independiente" (Ventura, 2002, p 141).. Aquí la indemnización ha sido vista como el medio más natural de reparar. La indemnización contempla la valoración económica del daño emergente, del lucro cesante, de los perjuicios morales, y en algunos casos del daño ocasionado al proyecto de vida ${ }^{14}$.

El daño moral e inmaterial es "la aflicción y el sufrimiento causados a las víctimas, el menoscabo de valores muy significativos para las personas, así como las alteraciones de carácter no pecuniario en las condiciones de existencia de la víctima. Dentro de estos daños inmateriales La Corte ha reconocido, aunque no siempre, daños de tipo moral, psicológico y físico de carácter colectivo. Este daño carece per se de valor económico y la indemnización compensatoria continúa siendo el medio de reparación más frecuente, aunque no el único, al momento de repararlo" (Ventura, 2002, p 141).

\footnotetext{
${ }^{13}$ Cfr. Caso Vargas Areco, supra nota 3, párr. 146; Caso Goiburú y otros, supra nota 5, párr. 150; y Caso Montero Aranguren y otros (Retén de Catia), supra nota 128, párr. 126.

${ }^{14} \mathrm{La}$ Corte IDH, ha reconocido indemnizaciones por daño al proyecto de vida familiar (caso Loayza Tamayo frente a Perú, 1998), personal (caso Myrna Mack Chang contra Guatemala, 2005), y social (caso Huilca Tecse frente a Perú, 2005).
} 
Por su parte, el daño moral proviene de los efectos psicológicos generados por la agresión que sufrió la persona o sus familiares, como consecuencia directa de la violación de derechos. Este daño va directo a la psiquis de la persona, es decir, trae sufrimiento y padecimientos a quien ha sido sometido, se produce sobre su honra, y representa uno de los tipos de daños a los cuales la Corte IDH se ha referido de manera explícita y precisa en su jurisprudencia ${ }^{15}$. En algunos casos es obligatorio probarlo, salvo cuando se torne evidente ${ }^{16}$.

De acuerdo con Beristain (2010), la Corte Interamericana ha definido las medidas de reparación de la siguiente manera:

1. La restitución, que busca restablecer la situación previa de la víctima. Incluye entre otros, el restablecimiento de derechos, el retorno a su lugar de residencia, la devolución de bienes y el empleo.

2. La indemnización se refiere a la compensación monetaria por daños y perjuicios. Incluye tanto el daño material, como físico y moral (miedo, humillación, estrés, problemas mentales, reputación).

${ }^{15}$ Algunas sentencias de la Corte IDH referida al daño moral o inmaterial son: Ver Castillo Páez v. Perú, 1998 Corte I.D.H. (ser. C). No. 43, Mack Chang v. Guatemala, 2003 Corte I.D.H. (ser. C). No. 101 (25 de noviembre de 2003). Bulacio, 2003 Corte I.D.H. (ser. C). No. 100. Blake v. Guatemala, 1999 Corte I.D.H. (ser. C). No. 48. Loayza Tamayo v. Perú, 1997 Corte I.D.H. (ser. C). No. 33 Las Hermanas Serrano Cruz v. El Salvador, 2005 Corte I.D.H. (ser. C) C No. 120. Ver Fermín Ramírez v. Guatemala, 2005 Corte I.D.H. (ser. C). No. 126. Cantoral Benavides v. Perú, 2001 Corte I.D.H. (ser. C). No. 88. Masacre Plan de Sánchez v. Guatemala, 2004 Corte I.D.H. (ser. C) No. 116.

${ }^{16}$ Resulta evidente el daño causado cuando la víctima ha sido sometida a agresiones y vejámenes de magnitud considerable lo que conlleva al sufrimiento moral. 
3. La rehabilitación alude a medidas tales como la atención médica y psicológica, así como servicios legales y sociales que ayuden a las víctimas a readaptarse a la sociedad. Las medidas de satisfacción se refieren a la verificación de los hechos, al conocimiento público de la verdad y a los actos de desagravio; las sanciones contra perpetradores; la conmemoración y el tributo a las víctimas.

4. Las garantías de no-repetición pretenden asegurar que las víctimas no vuelvan a ser objeto de violaciones. También requieren reformas judiciales, institucionales y legales, cambios en los cuerpos de seguridad, promoción y respeto de los derechos humanos, para evitar la repetición de las violaciones. (Beristain, 2010, p.85).

\subsubsection{Reparación colectiva en el ámbito internacional}

Acorde con los instrumentos internacionales ${ }^{17}$, la noción de víctima incluye a personas tanto individuales como colectivas, que hayan sufrido daños por violación a sus derechos humanos. Los daños de carácter colectivo y social refieren vulneraciones derivadas de violaciones que afectan a un grupo de personas o población determinada más allá de las afectaciones de carácter individual.

Estos daños han sido reparados principalmente en los casos de masacres o de vulneración de los derechos de pueblos indígenas y tribales, u otras colectividades, cuando se afecta el tejido

\footnotetext{
${ }^{17}$ Conjunto de normas del derecho internacional de los derechos humanos, la declaración sobre los principios fundamentales de justicia para las víctimas de delitos y del abuso de poder y los principios y directrices básicos sobre el derecho de las víctimas de violaciones manifiestas de las normas internacionales de derechos humanos y de violaciones graves del derecho internacional humanitario a interponer recursos y obtener reparaciones.
} 
social. En estas situaciones el daño ha sido resarcido a través de medidas restitutorias (derechos sobre el territorio) ${ }^{18}$, indemnizatorias ${ }^{19}$, de satisfacción (creación de centros de educación, salud, caminos, recuperación de la cultura indígena), garantías de no repetición (base de datos genéticos $^{20}$, campañas de concientización para la población ${ }^{21}$ ) y de otro tipo, a través de programas de desarrollo o socio educativos en beneficio de la comunidad ${ }^{22}$.

Para autores como Beristain (2010):“La reparación colectiva debe ser vista como el conjunto de medidas interdependientes en el contexto de una comunidad en proceso de recuperación. El citado autor, hace referencia a diversos tipos de comunidades o grupos afectados por distintas violaciones, con un número significativo de víctimas y que tienen, por otra parte, efectos colectivos en varios ámbitos”. Estos son:

\section{Tipos de casos colectivos: Corte y Comisión Interamericana}

1. Masacres en comunidades indígenas (Caloto-Masacre del Nilo, Plan de Sánchez, Moiwana) u otras comunidades (Mapiripán, Pueblo Bello, El Aro y La Granja, Dos Erres).

2. Masacres de otros colectivos (19 Comerciantes, La Rochela, Barrios Altos, Caracazo), incluyendo violaciones reiteradas a un grupo político en diferentes momentos (UP).

3. Comunidades indigenas con violaciones del derecho a la tierra (Awas Tingni, Yakye Axa y Sawhoyamaxa).

4. Violaciones a un colectivo de derechos laborales (Cinco Pensionistas, Baena).

5. Violaciones colectivas en régimen carcelario (Retén de Catia, Panchito López).

\footnotetext{
${ }^{18}$ Véase los casos Comunidad Mayanga (Sumo) Awas Tingi, Comunidad Sawhoyamaxa, Comunidad Yake Axa.

${ }^{19}$ Véase los casos Aloeboetoe y otros, Comunidad Mayanga (Sumo) Awas Tingi, Comunidad Sawhoyamaxa, Comunidad Yake Axa.

${ }^{20}$ Véase casos Molina Theissen, Hermanos Serrano Cruz, Masacre de Mapiripán.

${ }^{21}$ Véase casos Servellón y Campo Algodonero.

${ }^{22}$ Véase casos Aloeboetoe y otros, Plan de Sánchez, Comunidad Indígena Yakie Axe, Comunidad Moiwana, Comunidad Sawhoyamaxa.
} 
Figura 1. Tipos de Colectivos Corte $\mathrm{IDH}^{23}$

Beristain (2010), indica, que "la consideración del número de víctimas y de sus graves efectos colectivos, existen diferencias entre la valoración jurídica del tipo de derechos violados en estos casos, ya sea porque se estimen como la suma de violaciones individuales, o bien como violaciones al colectivo. La reparación colectiva se caracteriza por la posibilidad de incidir en un número importante de personas o comunidades y plantea desafíos en cuanto a la definición de los beneficiarios y los intereses individuales o grupales que se manifiestan".

La reparación tiene también como propósito, el reconocimiento de las víctimas como sujetos de derechos y de ciudadanía que son pilares en la reconstrucción de la confianza cívica, del Estado de derecho y del tejido social.

En el Sistema Interamericano de Derechos Humanos las reparaciones colectivas han sido objeto de muchos pronunciamientos a través de los casos contenciosos. A través de la jurisprudencia de la Corte IDH se ha logrado establecer elementos que facilitan el entendimiento de la denominada reparación colectiva. De acuerdo con lo expresado por Beristain (2010):

La reparación colectiva no ha nacido de la consideración de un sujeto de derechos colectivo, sino del impacto colectivo producido por las violaciones. [...] algunos casos de violaciones como masacres también han conllevado reparación relacionada con estos derechos colectivos. [...] Esto muestra una relación más holística entre diferentes tipos de derechos, así como la importancia de una perspectiva más global en la reparación,

\footnotetext{
${ }^{23}$ Datos obtenidos de Berestein (2010, p.65).
} 
considerando las condiciones necesarias para reconstruir el tejido social, y no solo la valoración del impacto producido (p.379).

Sin embargo, aunque existe un debate abierto sobre las violaciones de derechos económicos o sociales, la Corte ha ordenado en varias ocasiones reparaciones de carácter colectivo, en consideración a las particularidades de cada caso. En el caso Plan de Sánchez, además de determinar la reparación económica para las víctimas individuales, la Corte estimó el daño colectivo debido al impacto de la militarización y del asesinato de mujeres, ancianos o líderes en el ámbito cultural y ordenó en este sentido algunas reparaciones de carácter colectivo (p.355).

\subsubsection{Experiencias internacionales de reparación colectiva}

A continuación, se presentan dos casos representativos de reparaciones que han sido ejemplo y referente para toda Latinoamérica, que ha sufrido problemas de conflicto y afectación de los derechos humanos de la población.

Chile sufrió los rigores de la dictadura militar de Pinochet entre 1996 y 2008. "El Gobierno chileno destinó más de 1.600 millones de dólares para conceder pensiones a ciertas víctimas del régimen de Pinochet e instituyó un programa sanitario especial para los supervivientes de violaciones de derechos humanos. Todo ello fue acompañado de una disculpa oficial por parte del presidente". (ICTJ, 2016). 
"La responsabilidad del Estado en las violaciones de derechos humanos fue denunciada ante los Tribunales de Justicia y ante los organismos internacionales desde 1973, dejando así numerosos registros sobre las violaciones de derechos humanos cometidas en el período. Cada uno de los informes especiales sobre Chile, de la Comisión Interamericana de Derechos Humanos y los informes anuales hasta 1989, registraron estas denuncias”. Lira (como se citó en Instituto Interamericano de Derechos Humanos, 2011, p. 88).

“La Comisión recibió distintos casos del régimen y les hizo seguimiento. El régimen militar respondió justificando algunas veces la actuación de las autoridades, pero en muchos casos no dio respuesta, al negar la detención de las personas e incluso, su existencia legal, desligándose de toda responsabilidad. A su vez, la Asamblea General de Naciones Unidas dictó resoluciones condenatorias al régimen militar chileno desde 1974 hasta 1989. La primera condena fue consecuencia de la presión de la comunidad internacional, por las denuncias de violaciones de derechos humanos que ocurrían en Chile. En cada una de las resoluciones se insistió en la falta de información acerca de personas desaparecidas. Naciones Unidas nombró una comisión para investigar las situaciones denunciadas y luego fueron designados relatores especiales que mantuvieron el seguimiento sobre los casos denunciados hasta el fin de la dictadura". Lira (como se citó en Instituto Interamericano de Derechos Humanos, 2011, p. 88).

“Las políticas de reparación se concretaron en programas específicos, dirigidos a compensar las numerosas violaciones de derechos humanos por los daños causados, es decir, rehabilitar y desagraviar a las víctimas y restituir y restaurar sus derechos. Las medidas de resarcimiento que fueron adoptadas se basaron en el reconocimiento y en la identificación individualizada de 
quienes fueron considerados víctimas en cada una de esas situaciones, mediante programas de carácter administrativo creados por ley. El restablecimiento de la dignidad de las víctimas no descansa únicamente en los procesos judiciales, sino también en las acciones simbólicas del Estado, especialmente en aquellas que contribuyen a garantizar, hacia el futuro, condiciones políticas y culturales para que nunca más las violaciones a los derechos humanos se realicen ni justifiquen en nombre del bien común de la nación”. Lira (como se citó en Instituto Interamericano de Derechos Humanos, 2011, p. 101- 102).

"Para el caso de los países de América Latina, otro de los referentes que merece ser analizado es el caso del Salvador. Este país, sumido en un periodo de violencia interna sufrió el irrespeto a las mayorías populares, materializado en la violación sistemática de su dignidad, que fue causa y consecuencia de una guerra que durante más de once años destrozó vidas y valores, infraestructura y patrimonios; despedazó una sociedad que de incluyente y equilibrada en sus diversos ámbitos, no tenía nada. Esa realidad le negaba equidad, justicia y participación política al conjunto más amplio de la población. El cambio total de semejante escenario era la aspiración generalizada que se afincó, dentro y fuera del país al final del largo enfrentamiento armado entre el Gobierno de la época y el entonces insurgente Frente Farabundo Martí para la Liberación Nacional (FMLN)" Cuéllar (como se citó en Instituto Interamericano de Derechos Humanos, 2011, p. 165).

"La dimensión del drama humano salvadoreño, por su número y sus características, la certificó el informe de la Comisión de la Verdad. Su sugerente título reflejaba lo dicho: "De la locura a la esperanza". Las causas estructurales que ampliaron la represión gubernamental, 
generaron la violencia guerrillera y desataron el conflicto bélico -con sus manifestaciones más atroces - constituyeron la máxima expresión de la primera. En tal contexto, y durante un largo período, el desempeño del sistema de justicia permaneció "atrapado sin salida" por los poderes fácticos. Pasada "la locura", asomó la "esperanza" de construir un El Salvador distinto. Una "casa común" donde toda la gente, sin distingo, habitara; un hogar edificado con unos "planos" en los que estaban claros sus cimientos (...) Verdad y justicia para las víctimas de violaciones al Derecho Internacional de los Derechos Humanos y al DIH, que fueron graves y cuantiosas. Se estima en 70.000 las víctimas fatales de dicha guerra, entre 1980 y 1992.”. Cuéllar (como se citó en Instituto Interamericano de Derechos Humanos, 2011, p. 165).

“A lo anterior, se suma el Tribunal para la Aplicación de la Justicia Restaurativa en El Salvador, con las demandas de las víctimas y las recomendaciones de sus integrantes. Entre las primeras están, la derogatoria de la amnistía; el acompañamiento psicosocial a las víctimas, sus familias y las comunidades afectadas; crear un programa de becas para que los hijos y las hijas de las víctimas realicen estudios superiores; desaparecer todo signo de homenaje o reconocimiento a los responsables de las atrocidades; incorporar en el sistema educativo el conocimiento del pasado reciente del país; construir el Museo Nacional de la Memoria; crear un fondo nacional de reparación individual y colectiva con mecanismos expeditos y asequibles, sin descartar procedimientos de mediación y conciliación siempre que sean recíprocamente aceptados; verificar el cumplimiento de los compromisos asumidos por el Estado salvadoreño ante el Consejo de Derechos Humanos de las Naciones Unidas, la Comisión Interamericana de Derechos Humanos y otros organismos internacionales" Cuéllar (como se citó en Instituto Interamericano de Derechos Humanos, 2011, p. 165). 


\subsection{Estándares Nacionales sobre el Derecho a la Reparación}

El marco normativo para reparación de las víctimas en Colombia, surge a partir de la propia Constitución Política en los artículos $1^{\circ}$ (Estado social de derecho y dignidad humana), artículo 2 (eficacia de los derechos y orden justo), artículo 20 (derecho a ser informado de la verdad), artículo 58 (propiedad privada), artículo 90 (responsabilidad del Estado), artículos 95-2 (deberes de las personas) y artículo 201-2 (continuidad de la responsabilidad civil de una persona favorecida con indulto), (Constitución Política de Colombia, 1991), sistema normativo desarrollado por un conjunto de normas tales como:

La Ley 446 de 1998 (artículo 16) ${ }^{24}$. El artículo 2341 y siguientes del Código Civil que establece la responsabilidad civil extracontractual de los particulares.

El artículo 86 del Código Contencioso Administrativo ${ }^{25}$, contiene la acción de reparación directa, ante la justicia administrativa, que permite interponer demandas de responsabilidad patrimonial extracontractual del Estado.

La Ley 472 de 1998, reglamenta las acciones populares y de grupo, para la protección de los derechos colectivos, en el primer caso, o para la indemnización del daño ocasionado a más de 20 víctimas de un daño que tiene una causa común.

\footnotetext{
${ }^{24}$ Consagra el deber de "reparación integral" de las víctimas de los daños, lo cual ha sido avalado por la jurisprudencia constitucional en La Sentencia C-965, de la Corte Constitucional del 2003, donde la jurisprudencia contenciosa sobre el punto es abundante, tanto en materia contractual como extracontractual.

${ }^{25}$ Decreto-Ley 01 de 1984. El artículo 86 citado fue modificado por el artículo 31 de la Ley 446 de 1998
} 
Los artículos 94 a 100 del Código Penal ${ }^{26}$, regulan la responsabilidad civil derivada de la conducta punible, incluidos los perjuicios morales.

La Ley 975 del $2005^{27}$ constituye el primer esfuerzo del Estado colombiano para estructurar un sistema de justicia transicional para la terminación definitiva del conflicto armado interno, tiene por objeto "facilitar los procesos de paz y la reincorporación individual o colectiva a la vida civil de miembros de grupos armados al margen de la ley, garantizando los derechos de las víctimas a la verdad, la justicia y la reparación” (p.1).

La Ley como mecanismo de justicia transicional, establece acciones judiciales contra los autores individuales de crímenes, ya sea por medio de tribunales nacionales o internacionales; la promoción de la búsqueda de la verdad para esclarecer abusos pasados y construir la memoria histórica; y la reparación, tanto material como inmaterial, de las víctimas de violaciones de derechos humanos Duggan (como se citó en Valencia \& Mejía, 2010, p. 64).

El Decreto 1290 de 2008 estableció por primera vez “el programa de reparación individual por vía administrativa para las víctimas de los grupos armados organizados al margen de la ley".

La Ley 1448 de 2011, "Por la cual se dictan medidas de atención, asistencia y reparación integral a las víctimas del conflicto armado interno y se dictan otras disposiciones”. Esta ley fue

\footnotetext{
${ }^{26}$ El Código Penal está contenido en la Ley 599 del 2000.

${ }^{27}$ La Ley 975 del 2005, denominada "de Justicia y Paz", por la cual se dictan disposiciones para la reincorporación de miembros de grupos armados organizados al margen de la ley, que contribuyan de manera efectiva a la consecución de la paz nacional y se dictan otras disposiciones para acuerdos humanitarios establece en sus artículos 1, 4, 8, 42 y 49 la reparación colectiva. La Corte Constitucional se ha pronunciado ya sobre esta ley. Ver sentencias C-319, C-370, C-575 y C-650, todas del 2006.
} 
reglamentada por el Decreto 4800 de 2011, el cual aborda el procedimiento del Registro Único de Víctimas del Conflicto Armado, al igual que por otros decretos concernientes al tema de reparación de grupos indígenas, afrodescendientes etc. Esta ley constituye el marco normativo que regula el derecho a la reparación de las víctimas del conflicto armado interno en Colombia. "Mediante esta ley se establecieron los mecanismos y herramientas para brindar asistencia, atención y reparación a las víctimas, mediante la implementación de un programa masivo de reparaciones que surge como complemento indispensable a la reparación de las víctimas en sede judicial”.

La Ley 1448 de 2011 es parte integral del "modelo nacional de Justicia Transicional del que hacen parte las Leyes: 975 de 2005, 418 de 1997, prorrogada y modificada por la Ley 1421 de 2010 y 1424 de 2010, entre otras. El Gobierno Nacional reconoce que la forma de construir un proceso de reconciliación nacional sobre bases sólidas de equidad e inclusión social, es a través de la materialización de los derechos de las víctimas y que, por ende, no se debe esperar a que el conflicto armado finalice para poner en marcha un programa administrativo de reparaciones".

Por otra parte, El Decreto 4800 de 2011 “crea las condiciones para que las víctimas del conflicto armado interno, participen como ciudadanos de manera activa en la recuperación y el ejercicio pleno de sus derechos políticos y económicos, sociales y culturales, en la reconstrucción del tejido social y en el fortalecimiento de la institucionalidad del Gobierno Nacional, responsable del diseño, ejecución e implementación de una política pública de atención, asistencia y reparación. En tal sentido y con el fin de garantizar la participación de las víctimas, sus organizaciones, representantes de la sociedad civil y entidades territoriales, el 
Gobierno Nacional activó diversas estrategias que permitieron la recepción de numerosos insumos de retroalimentación para que el decreto reglamentario de la Ley 1448 de 2011, se ajustara a las necesidades de las víctimas y a las realidades regionales".

El programa de asistencia, atención y reparación integral de la Ley 1448, "responde a la necesidad de reconocer los abusos cometidos en el desarrollo del conflicto armado, mitigar el dolor sufrido por las víctimas de las violaciones de que trata el artículo 3 de dicha Ley, implementar una serie de medidas que a su vez sirvan para complementar los procesos judiciales, y ofrecer oportunidades a las víctimas del conflicto. Al tenor de esta ley, el Gobierno reconoce que los esfuerzos de reparación a las víctimas no se pueden confundir con aquellos realizados en cumplimiento de las políticas sociales" (Decreto 4800, 2011).

La Ley 1448 de 2011 se estructura bajo ocho ejes fundamentales: (a) las disposiciones generales, (b) los derechos de las víctimas en los procesos judiciales, (c) los mecanismos de ayuda humanitaria, atención y asistencia, (d) las medidas de reparación, (e)institucionalidad para la atención y la reparación, (f) los mecanismos de protección integral de niños, niñas y adolescentes, (g) la participación de las víctimas y, (h) las disposiciones finales.

Las disposiciones generales contemplan el objeto de la ley, su ámbito, la definición de víctima y los principios rectores de la ley.

La Ley 1448 tiene por objeto regular las medidas judiciales, sociales y económicas, tanto individuales como colectivas, de las víctimas del conflicto armado en el marco de la justicia 
transicional, para así garantizar sus derechos a la verdad, justicia, reparación y no repetición, con una vigencia de 10 años. El ámbito de aplicación establece la ayuda humanitaria, la atención, asistencia y reparación de las víctimas.

La ley 1448 (2011) contempla una definición de víctima, como aquella persona que individual o colectivamente haya soportado daños por infracciones al derecho internacional humanitario o por violaciones de los derechos humanos, en el marco del conflicto armado interno, siendo también víctimas los conyugues, compañero o compañera permanente, parejas del mismo sexo, los familiares en primer grado de consanguineidad y a falta de estos, los de segundo grado de consanguineidad ascendente y los familiares en primer grado civil de la víctima directa cuando a esta se le hubiera asesinado o estuviera desaparecida.

Igualmente, la Ley precisa en los parágrafos 1 a 5 del artículo 3, una serie de aspectos relativos sobre el concepto de víctimas, en tal sentido señala que:

1. La condición de víctima se adquiere con independencia de que se individualice, aprehenda, procese o condene al autor de la conducta punible y de la relación familiar que pueda existir entre el autor y la víctima.

2. Cuando los miembros de la Fuerza Pública sean víctimas, su reparación económica corresponderá por todo concepto a la que tengan derecho, de acuerdo con el régimen especial que les sea aplicable. De igual forma, tendrán derecho a las medidas de satisfacción y garantías de no repetición señaladas en la presente ley. 
3. Los miembros de los grupos armados organizados al margen de la ley no serán considerados víctimas, salvo en los casos en los que los niños, niñas o adolescentes hubieren sido desvinculados del grupo armado organizado al margen de la ley, siendo menores de edad.

4. El o la cónyuge, compañero o compañera permanente, o los parientes de los miembros de grupos armados organizados al margen de la ley serán considerados como víctimas directas por el daño sufrido en sus derechos no como víctimas indirectas por el daño sufrido por los miembros de dichos grupos.

5. No serán considerados como víctimas quienes hayan sufrido un daño en sus derechos como consecuencia de actos de delincuencia común.

6. Las personas que hayan sido víctimas por hechos ocurridos antes del $1^{\circ}$ de enero de 1985 tienen derecho a la verdad, a las medidas de reparación simbólica y a las garantías de no repetición como parte del conglomerado social, sin necesidad de que sean individualizadas.

7. La definición de víctima no podrá en ningún caso interpretarse o presumir reconocimiento alguno de carácter político, sobre los grupos terroristas y/o armados ilegales, que hayan ocasionado el daño al que se refiere como hecho victimizante. (Sentencia C-052/12)

La Figura 2 muestra la síntesis el concepto de víctima de acuerdo con el DIDH, la Ley 975 del 2005 y Ley 1448 de 2011. 


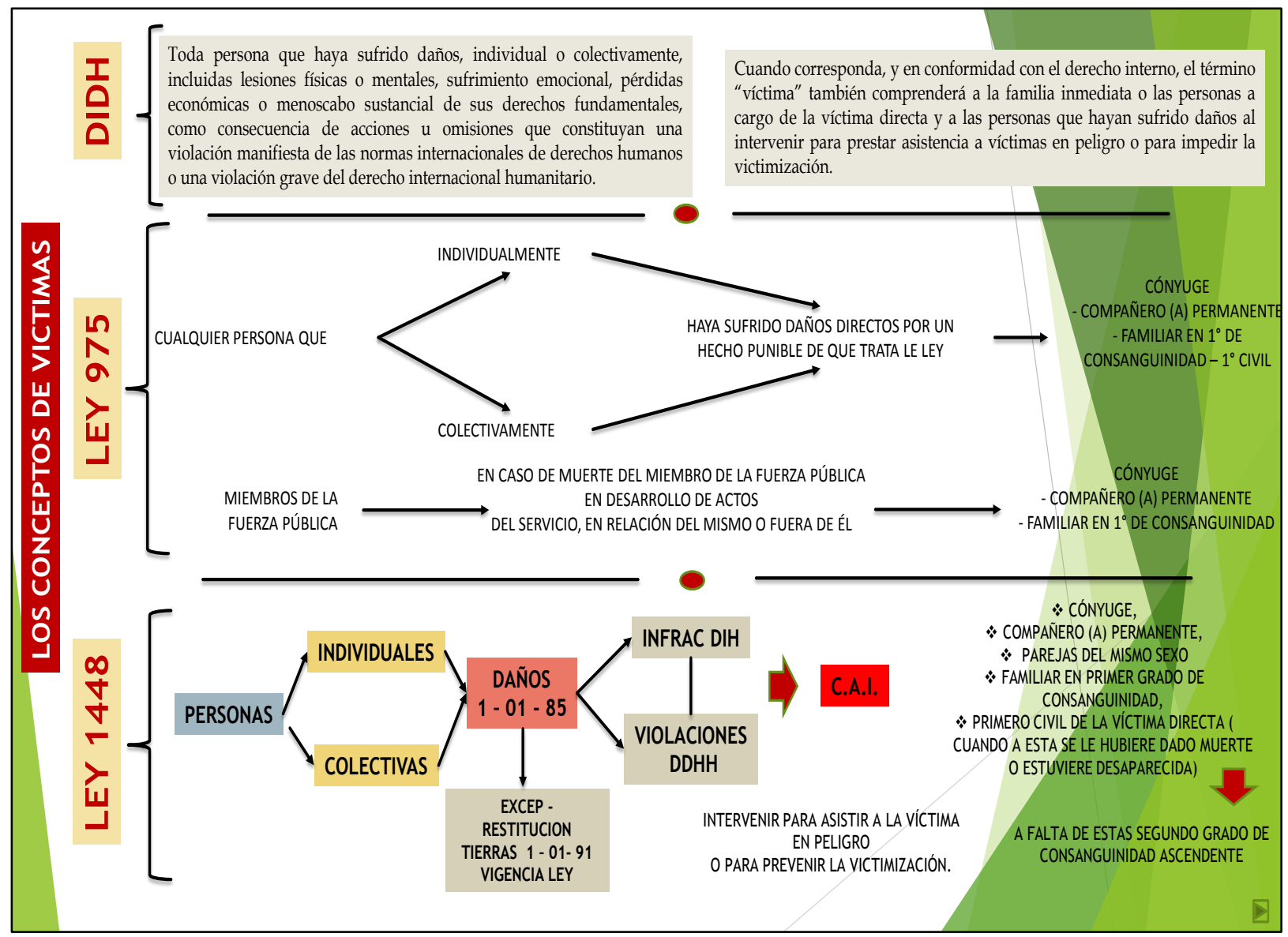

Figura 2. Concepto de Víctima ${ }^{28}$

La ley contempla un conjunto de principios, entre los que se pueden destacar, "la dignidad, la buena fe, la igualdad, la prohibición de doble reparación y de compensación, complementariedad y publicidad, el debido proceso, el carácter de las medidas transicionales, un enfoque diferencial; la obligación de sancionar a los responsables; progresividad, gradualidad y sostenibilidad, la acción de repetición y subrogación, los derechos a la verdad, la justicia y la reparación integral, medidas especiales de protección y criterios y elementos de revisión, participación de la sociedad civil y la empresa privada y compromisos del Estado”. (Ley 1448 de 2011).

\footnotetext{
${ }^{28}$ Elaboración propia.
} 
La Ley 1448 de 2011, en su artículo 8, contempla una definición de justicia transicional, al establecer que consiste en "los diferentes procesos y mecanismos judiciales o extrajudiciales asociados con los intentos de la sociedad por garantizar que los responsables de las violaciones rindan cuentas de sus actos, se satisfagan los derechos a la justicia, la verdad y la reparación integral a las víctimas, se lleven a cabo las reformas institucionales necesarias para la no repetición de los hechos y la desarticulación de las estructuras armadas ilegales”.

La ruta integral de asistencia a nivel general establece la reparación individual y colectiva. Para la primera contempla las medidas de reparación de restitución, rehabilitación, indemnización, medidas de satisfacción y las garantías de no repetición y para la segunda, planes de reparación colectiva para las comunidades y los grupos étnicos.

La Ley 1448 (2011), en sus artículos 25 y 69, establece las modalidades de reparación integral así:

1. Indemnización: su objetivo es la compensación material de un daño, una serie de medidas de carácter económico que se establece en montos de salarios mínimos legales mensuales vigentes al momento del pago, y que son sufragados por el estado a la víctima, de acuerdo con los daños ocasionados como consecuencia de infracciones al derecho internacional humanitario o a las graves violaciones de los derechos humanos con ocasión del conflicto armado interno, sin importar la identificación del victimario.

2. Rehabilitación: es el conjunto de estrategias, planes, programas y acciones de carácter 
jurídico, médico, psicológico y social, dirigidos al restablecimiento de las condiciones físicas y psicológicas de las víctimas.

3. Satisfacción: buscan proporcionar bienestar y contribuir a mitigar el dolor de la víctima. Su adopción ha de cumplirse mediante la participación de las víctimas, garantizando un enfoque diferencial y, a través del plan nacional de atención y reparación de las víctimas. Se realizarán acciones para restablecer la dignidad de la víctima y difundir la verdad sobre lo sucedido.

4. No repetición: el Estado debe adoptar proyectos y programas de no repetición que comprendan acciones afirmativas, económicas y políticas, cuando las violaciones graves y manifiestas al derecho internacional de los derechos humanos y a las normas internacionales de derechos humanos ya se han consumado, con el propósito de que las víctimas no vuelvan a sufrir estas violaciones.

5. Reparación colectiva: el Estado debe adoptar una serie de medidas ante los daños ocasionados por la violación de los derechos colectivos, la violación grave y manifiesta de los derechos individuales de los integrantes de un grupo y el impacto colectivo de la violación de los derechos individuales.

6. Restitución de tierras y viviendas: comprende las acciones de restitución de los despojados, los principios de la restitución, el despojo y abandono forzado de tierras y quiénes son los titulares del derecho a la restitución. (Ley 1448 de 2011). 


\subsubsection{La reparación colectiva en la ley 1448}

La Ley 1448 de 2011 reglamenta todo lo relacionado con la denominada reparación colectiva (artículos 151 y 152) el cual establece un conjunto de medidas y políticas estatales "referidas a reformas institucionales para fortalecer el Estado Social de Derecho, la participación política, la focalización de política pública y la inversión para el goce efectivo de derechos fundamentales; así como las medidas de rehabilitación social y comunitaria, las medidas de satisfacción, justicia, la construcción de memoria histórica y verdad".

Para tales efectos, "debe tener en cuenta el daño ocasionado por la violación de los derechos colectivos; la violación grave y manifiesta de los derechos individuales de los integrantes de un grupo y el impacto colectivo de la violación de los derechos individuales".

Igualmente refiere la ley que los sujetos de reparación colectiva son aquellos grupos y organizaciones sociales y políticas, y comunidades determinadas a partir del reconocimiento jurídico, político o social que se haga del colectivo o en razón de la cultura, la zona o el territorio donde habitan o de un propósito común y finalmente y que la implementación de las medidas de reparación se harán a través de Planes de Reparación Colectiva, "realizados por cada uno de los sujetos de reparación colectiva, a partir de un diálogo participativo con la institucionalidad. En este diálogo se concretan los acuerdos democráticos que dan lugar a la selección de las medidas de reparación, a partir del reconocimiento y dignificación de las víctimas, de acuerdo con el daño e impacto ocasionado, el contexto concreto, las expectativas de los sujetos de reparación colectiva y la oferta institucional". 
A continuación, se detallan las rutas de reparación colectiva:

Reparación Colectiva. El Capítulo VII del Decreto 4800 de 2011, en concordancia con la Ley 1448 de 2011, define la reparación colectiva como “el reconocimiento y la dignificación de organizaciones sociales y políticas, grupos y comunidades que han sufrido un daño colectivo. Con la reparación colectiva se busca la recuperación psicosocial, la inclusión ciudadana, la reconstrucción del tejido social, la devolución de la confianza en el Estado, así como la recuperación y el fortalecimiento del Estado Social de Derecho”.

Se entiende por reparación colectiva, el derecho que tienen sujetos colectivos por el quebrantamiento de alguno(s) de sus derechos de naturaleza comunitaria/colectiva o de los derechos individuales con una implicación no solo individual sino además colectiva, ante la acción u omisión de agente(s) de diversa índole, tanto legales como ilegales (por ejemplo, grupos armados ilegales en el marco de un conflicto armado). Este tipo de reparación abarca medidas de restitución, indemnización, satisfacción y garantías de no repetición en diversas esferas de acción, a saber: político, material/económico e inmaterial/simbólico. La reparación tiene como propósito compensar los daños morales y patrimoniales sufridos por sujetos colectivos.

El Decreto 4800 de 2011 señala que "la reparación colectiva tendrá un enfoque transformador y diferencial, en tanto propenda por eliminar los esquemas de discriminación y marginación de los sujetos colectivos que pudieron contribuir a la ocurrencia de los hechos victimizantes. La reparación colectiva, ofrecerá especial atención a las necesidades específicas 
de los miembros del sujeto de reparación colectiva que, en razón de su edad, género, orientación sexual y/o situación de discapacidad, que así lo requieran, garantizando su participación efectiva y adecuada en la toma de decisiones".

El Programa de Reparación Colectiva se implementa mediante planes de reparación colectiva, al seguir los pasos de una ruta que ha sido definida para ello. "Se inicia con el registro del sujeto colectivo, hasta la formulación por parte de las víctimas, y la implementación por parte de las entidades del Sistema Nacional de Atención y Reparación Integral a Víctimas (en Adelante el SNARIV) ${ }^{29}$, el cual es aprobado por el respectivo Comité Territorial de Justicia Transicional. El Plan, en función del diagnóstico del daño que se realice, puede contener medidas de satisfacción, restitución, rehabilitación y garantía de no repetición” (UARIV, 2013).

La figura 3, resume la ruta de reparación colectiva, al tenor de la legislación vigente en esta materia y las fases que han de seguirse para su realización (UARIV, 2013).

\footnotetext{
${ }^{29}$ El Sistema Nacional de Atención y Reparación Integral a las Víctimas (SNARIV) está constituido por el conjunto de entidades públicas del nivel gubernamental y estatal en los órdenes nacional y territoriales y demás organizaciones públicas o privadas, encargadas de formular o ejecutar los planes, programas, proyectos y acciones específicas, que tiendan a la atención y reparación integral de las víctimas (SNARIV, 2016)
} 


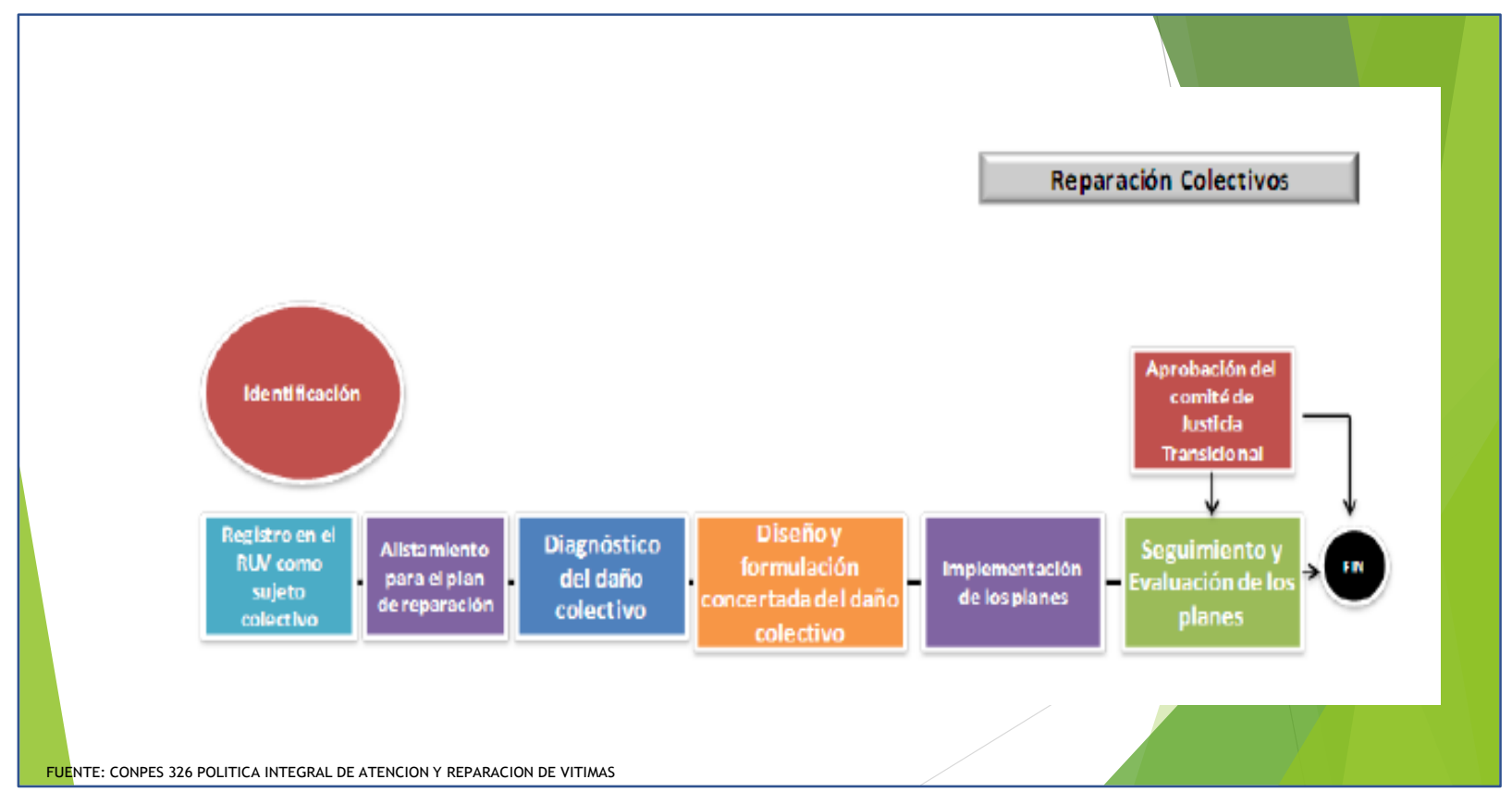

Figura 3. Ruta de Reparación Colectiva ${ }^{30}$.

\section{Fase de identificación del sujeto de reparación colectiva}

La Unidad Administrativa Especial para la Atención y Reparación a las Víctimas identificará los sujetos de reparación colectiva a través de dos modalidades por oferta y por demanda:

Modalidad por oferta, donde la Unidad para las Víctimas identifican los sujetos colectivos victimizados, a quienes se les expresará la voluntad del Estado de que participen del Programa de Reparación Colectiva y, en caso de ser aceptada la invitación, coadyuvará en las solicitudes de registro $^{31}$.

${ }^{30}$ Datos obtenidos de Conpes 326 (2016, p.2).

${ }^{31}$ REDEPAZ inició su proceso de Reparación Colectiva bajo la modalidad de Oferta, es decir, el Estado hizo una identificación inicial de la red como un sujeto colectivo a quien le fueron vulnerados los derechos y donde hubo graves afectaciones al tejido social. La repercusión del daño se dio no solo a nivel interno, en la red, sino que afectó un proceso de incidencia nacional y política, lo cual se describirá y se comprobará en el capítulo siguiente. 
En la modalidad por demanda, los sujetos de reparación colectiva no incluidos en la oferta del Estado realizarán el procedimiento de registro ante la Unidad de Víctimas (UARIV, 2013).

Fase de alistamiento para iniciar la construcción de los planes integrales de reparación colectiva. La Unidad Administrativa implementará los mecanismos para garantizar la participación de los sujetos de reparación colectiva, mediante una información oportuna, clara y precisa. Así mismo, se propone la identificación de necesidades y expectativas de reparación y la promoción del conocimiento reflexivo sobre el significado, objetivos, componentes y mecanismos de la política de reparación colectiva del Estado colombiano.

Fase de identificación y diagnóstico de los daños colectivos de los sujetos de reparación colectiva. Con el apoyo técnico de la Unidad Administrativa, se convocará abiertamente a todos los integrantes del sujeto de reparación colectiva, con quienes se definirá una metodología para la identificación y el diagnóstico de los hechos, daños, afectaciones, necesidades y expectativas de la reparación colectiva. Este proceso quedará consignado en un acta de caracterización del daño colectivo, que será la base para iniciar la fase de diseño y formulación de las medidas de reparación colectiva.

Fase de diseño y formulación concertada del Plan Integral de Reparación Colectiva. La Unidad Administrativa Especial para la Atención y Reparación Integral a las Víctimas, coordinará la realización de los talleres, espacios y actividades acordados en la fase de alistamiento con el fin de priorizar y definir los componentes y objetivos generales del Plan 
Integral de Reparación Colectiva para cada sujeto de reparación colectiva.

Fase de implementación. La implementación de los Planes Integrales de reparación colectiva se adelantará pronta y oportunamente, por parte de los responsables de su ejecución, de acuerdo con los tiempos y contenidos establecidos en el respectivo Plan.

Seguimiento, evaluación y monitoreo. La Unidad Administrativa Especial para la Atención y Reparación Integral a las Víctimas, diseñará y aplicará un sistema de seguimiento y evaluación que permita la medición y valoración periódica de la implementación y la ejecución de los planes integrales de reparación colectiva.

Información, divulgación y comunicaciones. La Unidad Administrativa Especial para la Atención y Reparación integral a las Víctimas, diseñará una estrategia de comunicaciones que garantice el acceso de los sujetos de reparación colectiva a las medidas y mecanismos del Programa de Reparación Colectiva.

Complementariedad y coherencia. El Programa de Reparación Colectiva y los Planes Integrales de Reparación Colectiva que construyan los sujetos de reparación colectiva, deberán articularse con las medidas de reparación integral establecidas en el Decreto para garantizar la coherencia y complementariedad con la política de asistencia, atención y reparación integral.

Una vez realizado el análisis de los marcos normativos del derecho a la reparación y sus desarrollos a nivel internacional y nacional, se procederá a analizar el caso específico de la Red de Iniciativas en Favor de la Paz y en contra de la Guerra REDEPAZ. 


\section{Caracterización de la Red de Iniciativas Ciudadanas por la Paz y contra la Guerra REDEPAZ}

\subsection{Contexto}

Desde mediados de los años ochenta, las organizaciones sociales y comunitarias del orden municipal, regional y nacional en Colombia impulsaron iniciativas de construcción de paz y reconciliación, mediante diversos mecanismos y dispositivos como las denominadas asambleas territoriales constituyentes por la paz, los territorios de paz, los espacios humanitarios, las comunidades de paz, las redes regionales por la convivencia y el desarme, el movimiento de madres por la vida, el movimiento de niños y niñas por la paz, la red de jóvenes constructores de paz y los programas de desarrollo y paz, entre otros.

A finales de los ochenta y principios de los noventa, se firman acuerdos de paz entre diferentes grupos alzados en armas y el gobierno nacional. Así abandonan las armas el M-19, el PRT, el Movimiento Quintín Lame y el EPL. El gobierno del presidente César Gaviria adelantó una Asamblea Nacional Constituyente el 9 de diciembre de 1990. En julio de 1991, entró en vigor la nueva carta constitucional que introdujo importantes y profundas reformas al sistema político colombiano.

Sin embargo, hay un escalamiento del conflicto armado interno por parte de los llamados grupos paramilitares, los esfuerzos por encontrar una solución llevaron al recrudecimiento de la violencia hacia las organizaciones sociales, comunitarias y grupos que trabajaban en favor de la 
paz, al ser consideradas por tales grupos armados como objetivos militares del conflicto. A pesar de los cambios suscitados por la Constitución de 1991, recrudece la violencia armada en todo el territorio nacional: desplazamiento forzado, desapariciones forzadas, ejecuciones extrajudiciales, masacres y actos de barbarie, secuestros, homicidios, genocidios, reclutamiento forzado, torturas, violencia sexual, minas antipersona, etc.

Para el 2002, en el primer periodo presidencial de Álvaro Uribe Vélez, se introdujo con fuerza la idea de que el país no padecía un Conflicto Armado Interno, conforme a las normas del DIH y el Gobierno argumenta que la situación de conflicto en el país se debía estrictamente a las acciones de grupos armados terroristas, los cuales debían ser combatidos con mecanismos e instrumentos jurídicos y militares, diferentes a los que se utilizan en una confrontación militar interna de carácter político.

Con el fracaso de los diálogos del Caguán en el año 2002 y la escalada de las acciones bélicas, las organizaciones y los grupos sociales continuaron su labor bajo un amplio repertorio de victimizaciones, restricciones sociales y políticas, así como estigmatización de los diferentes actores políticos y militares.

Esta negación del conflicto y la legitimación del "terrorismo", causó que tanto a los grupos guerrilleros como a los representantes de las organizaciones constructoras de paz, defensoras de derechos humanos, sindicales y sociales fueran señalados como miembros de la acción terrorista. El estado deslegitima el trabajo humanitario de estas organizaciones y, por el contrario, realizó acciones ilegales en contra de ellas. 
Al desaparecer, el concepto Conflicto Armado Interno, todos los desarrollos legales y políticos que Colombia había alcanzado fueron desmontados, en especial los desarrollados para hacer efectivo el artículo 22 de la Constitución Política Nacional "La paz es un derecho y un deber de obligatorio cumplimiento".

Álvaro Uribe Vélez establece una ley de orden público (Ley 782 de 2000) con el fin de posibilitar los procesos de paz, suprimir el carácter político de las guerrillas y dar el mismo tratamiento a esta y a los grupos paramilitares. En el 2002, los grupos paramilitares ${ }^{32}$ agrupados en las AUC declaran un cese unilateral de hostilidades y solicitan al gobierno conversaciones en perspectiva de su desmovilización y reinserción, teniendo como horizonte la posibilidad de garantías jurídicas favorables que incluyeron los graves crímenes de guerra y los delitos de lesa humanidad cometidos por los grupos de las AUC, así como las solicitudes de extradición por narcotráfico exigidas por Estados Unidos para la mayoría de sus jefes y narcotraficantes vinculados a sus filas (Villarraga, 2015).

El proceso logró la desmovilización y reincorporación de un gran número de paramilitares que operaban en el país; sin embargo, reaparecen nuevos. Algunos mantuvieron las estructuras políticas originales, otros conformaron grupos de delincuencia organizada, llamados por el gobierno: "Nuevas Bandas Criminales Emergentes" y otros constituyeron nuevas estructuras de narcotráfico. En los tres casos estos grupos delincuenciales desarrollan actividades similares con funciones de control territorial, político, social y de apoyo al narcotráfico. En este marco se

\footnotetext{
${ }^{32}$ El fenómeno del paramilitarismo hunde sus raíces en el uso de civiles armados por parte de partidos políticos, de capos locales, del gobierno y las fuerzas armadas. Tiene una larga tradición en el país que se remonta a las guerras civiles del siglo XIX y la guerra regional de los años 30 del siglo XX. En plena vigencia del Frente Nacional el paramilitarismo comienza su institucionalización en la lucha contra la amenaza comunista dentro de la estrategia de la guerra fría con la utilizaron de civiles para combatir la insurgencia, sus bases de apoyo y los políticos afectos a su causa.
} 
establece la Ley 975 de 2005 y se da inicio al proceso de estructuración de la justicia transicional en el país.

Con la llegada a la Presidencia de la República de Juan Manuel Santos en 2010, se reconoce nuevamente la existencia del Conflicto Armado Interno, se producen cambios significativos en beneficio de las víctimas y sus organizaciones, quienes adquieren mayor protagonismo en la agenda política nacional. También se avanza sustancialmente en el establecimiento de condiciones para la búsqueda de salidas políticas pacíficas y negociadas al conflicto armado. Estas reivindicaciones de las víctimas y los esfuerzos de negociación para el fin del conflicto armado cuentan con un importante reconocimiento social que, asociado a la garantía del goce de estos derechos, constituye una condición indispensable para avanzar en la reconciliación y construcción de la paz en Colombia (Sanabria, 2014).

Con la aprobación de la Ley de Víctimas y Restitución de Tierras (Ley 1448 de 2011), el concepto político da un giro hacia la definición de los fenómenos de violencia armada organizada por parte del Estado colombiano. El primero hace referencia al reconocimiento (nuevamente) de la existencia en el país de un Conflicto Armado Interno y del carácter político de esta confrontación. El segundo, derivado de este, reconoce, define y delimita el concepto de víctima, así como sus derechos a la verdad, la justicia, reparación y garantías de no repetición, y considera a estas personas como sujetos de derechos, como actores sociales y políticos definitorios para la construcción de la paz y la reconciliación nacional.

Aunque el reconocimiento de los derechos de las víctimas a la verdad, la justicia y la 
reparación se produce en el año 2005 con la llamada Ley de Justicia y Paz (Ley 975 de 2005), no es sino hasta la Ley de Víctimas y Restitución de Tierras en el 2011 que se establece el reconocimiento político de estas, el cual da lugar a procesos de reparación individual y colectiva a grupos, organizaciones y comunidades víctimas del conflicto armado. Esta decisión política, convertida en ley de la república, con escasos antecedentes en el contexto internacional, plantea complejos retos políticos, sociales, administrativos e institucionales en medio del conflicto armado.

Es evidente que el Estado colombiano ha avanzado en el reconocimiento de los derechos de las víctimas, en particular con el desarrollo de la verdad no judicial y desde esta la recuperación de los sueños perdidos, la reconstrucción del tejido social y las apuestas políticas de las organizaciones comunitarias, políticas y sociales que se vieron afectadas por las acciones de los grupos armados.

Con la Ley de Víctimas y Restitución de Tierras, se ha hecho evidente la necesidad de recuperar los tejidos sociales afectados, rotos o lesionados, para que desde el ejercicio de reconstrucción de memoria transformadora, los procesos de reparación, en especial, los que tienen carácter colectivo (retornos, reubicación, reparación colectiva de carácter nacional o local), aporten sustancialmente a la construcción de la reconciliación, al desarrollo de nuevas ciudadanías, a la recuperación de la organización ciudadana en el territorio y a la participación política de las organizaciones reparadas y de los individuos que las conforman.

En todo este proceso político y social se evidencia que el Estado colombiano no es el único 
agente que ha posicionado el tema de los derechos de las víctimas y construcción de paz en el contexto local o nacional, la ley y el proceso de construcción de paz en Colombia ha sido más el resultado de diversas y complejas iniciativas y escenarios que fomentan diversos sectores de la sociedad civil en alianza con sectores políticos democráticos desde hace varias décadas.

Desde la sanción de la Ley de Víctimas y Restitución de Tierras, se ha intentado implementar "una ambiciosa (aunque no suficiente) política de reparaciones que ha necesitado la creación de una institucionalidad específica, lo que ha demandado el desarrollo de conocimiento técnico, la movilización política de entes nacionales y territoriales, así como recursos financieros. Esto ha requerido que el Estado recoja las experiencias de muchas de las organizaciones con el objeto de que la reparación tenga un enfoque transformador y le plantea que debe reconocer la importancia del mensaje de resistencia y defensa de los derechos que las organizaciones de víctimas han posicionado durante años” (Sanabria, 2014).

Desde la promulgación de la ley, existen una serie de casos identificados para dar inicio a procesos de reparación colectiva a comunidades localizadas a lo largo y ancho del territorio nacional. Algunos de estos casos responden a organizaciones y grupos como la Asociación Nacional de Usuarios Campesinos (ANUC), el Instituto Popular de Capacitación (IPC), así como sindicalistas, periodistas, concejales y diputados, la Unión Patriótica y REDEPAZ. Los casos nacionales hacen parte de varias organizaciones que por sus características son representativas de un universo de iniciativas de la sociedad que se ha visto afectado por el conflicto.

Desde el punto de vista político y psicosocial, la reparación colectiva de los grupos y 
organizaciones plantea retos particulares. En este marco, el proceso de reparación colectiva ha desencadenado la necesidad de desarrollar instrumentos y metodologías que trasciendan la organización y se conviertan en instrumentos que incidan en otros grupos y organizaciones y en la sociedad en su conjunto.

\subsection{La Red de Iniciativas Ciudadanas por la Paz y en Contra de la Guerra REDEPAZ}

Los procesos de desmovilización e inclusión social y política operados en los años noventa conllevaron a una transformación política, social, institucional y normativa de hondas proporciones, lo que implicó una extensa y profusa investigación académica y social, que ha resultado insuficiente para entender en su entera dimensión algunos fenómenos de la vida social y política del país.

Uno de los fenómenos sociales y políticos menos estudiados es el crecimiento inusitado y exponencial en una diversidad de niveles territoriales, grupos etarios y diversidad estructural de las que hoy se denominan organizaciones no gubernamentales de paz y derechos humanos.

Aún es necesario explicar cómo en el país una gran variedad de organizaciones no gubernamentales ha logrado incidir en una diversidad de agendas sociales, económicas y políticas, en algunos casos en abierta confrontación con el sistema de partidos políticos. Esa riqueza ha permitido la construcción de vastas estructuras de redes sociales que se asocian mutuamente para crear redes de organizaciones no gubernamentales como REDEPAZ. 
La génesis de REDEPAZ se remonta a noviembre de 1993 en un esfuerzo de articulación de más de 400 delegados y delegadas participantes del Encuentro Nacional de Iniciativas contra la Guerra y por la Paz (Redepaz, 1993). Estructuralmente REDEPAZ está conformada por una variedad de subsistemas organizativos, políticos, sociales, comunicacionales, ideológicos, territoriales y relacionales. En su estructura funcional cuenta con dos subsistemas; de una parte, una vasta organización social articulada, integrada por organizaciones, movimientos, prácticas sociales, así como una diversidad de experiencias que desarrollan de manera individual y/o colectiva acciones en favor de la paz y en contra de la guerra; de otra parte, un estructura política, administrativa y legal como persona jurídica legalmente constituida, cuyo radio de acción se expande en gran parte del territorio nacional, en sus diversos ámbitos, como ya se mencionó (Redepaz, 2014 a).

REDEPAZ es también un sistema sociopolítico que ha logrado en más de dos décadas consolidar una sensibilización en contra de la guerra y en favor de la paz y la reconciliación del país, mediante un proceso dinámico, permanente y sostenido por fortalecer y posicionar de manera coordinada expresiones civiles de reconciliación. Además, una propuesta plural de reflexión y acción para el mutuo reconocimiento como sujetos de derechos y para la transformación democrática de la sociedad colombiana, manifestada en acciones sociopolíticas como las constituyentes municipales, la Semana por la Paz, el voto de los niños por la paz, entre otras iniciativas que le han valido reconocimiento nacional, internacional y territorial y convertirse en un referente en el imaginario colectivo a favor de la paz y en contra de la guerra. (Redepaz, 2017 a). 
Como sistema político REDEPAZ se nutre, además, de una diversidad de iniciativas sociales, políticas y de negociación con el Estado colombiano, presentes en los diferentes territorios de la geografía nacional, tales como Derrotemos la Guerra (Santander), Iniciativas Ciudadana por la Paz (Bogotá), Mesa de Trabajo por la Vida (Medellín), Corriente de Renovación Socialista, Milicias de Medellín y los procesos ciudadanos denominados Pactos por la Vida que se realizan en varias ciudades del país (Redepaz, 2014).

REDEPAZ es una estructura pluralista y democrática abierta a muchos actores y organizaciones comprometidas con la promoción de la paz y la no violencia. Como sistema ideológico se fundamenta en el principio de una ética ciudadana de respeto por la vida y en el tratamiento pacífico de los conflictos. Está comprometida en la construcción de una democracia social y económica que permita el acceso a la justicia sin recurrir a la guerra y en un proceso de nación que tenga como ejes la paz, la civilidad y la democracia.

En tal sentido, REDEPAZ ha logrado constituirse en una fuerza de opinión y de acción ciudadana que exige responsabilidad a los actores de la guerra, para no seguir asistiendo a la descomposición humana y cultural de la Nación (Redepaz, 2016 a).

En su estructura funcional, política, administrativa y legal, REDEPAZ se encuentra gobernada por una asamblea nacional, además de otras áreas de articulación, tales como ${ }^{33}$ :

1. Una asamblea nacional que se reúne cada dos años y es la máxima instancia de decisión de las políticas de la organización.

\footnotetext{
Redepaz.

${ }^{33}$ Estatutos Corporación para la Paz y los Derechos Humanos Redepaz- Certificado de Existencia y Representación Legal
} 
2. Un comité de coordinación política nacional que se reúne semestralmente y es un equipo de trabajo compuesto por 12 representantes de cada mesa de trabajo por la paz departamental y regional.

3. Una presidencia colegiada compuesta por tres miembros elegidos democráticamente en la asamblea nacional y se encarga de coordinar y ejecutar las políticas definidas en la asamblea.

4. Un comité de veeduría nacional que se compone de dos personas elegidas democráticamente en la asamblea nacional y el ente encargado de vigilar y asesorar el cumplimiento de los principios fundacionales y las decisiones de la asamblea. (Redepaz 2015a).

Cada proceso sectorial y/o regional realiza periódicamente encuentros que determinan su accionar autónomo y en red, de tal forma que la dinámica organizativa se renueva y retroalimenta, no solamente en los encuentros nacionales sino también en encuentros específicos como el Encuentro de Madres por la Vida y Encuentros de Mujeres Constructoras de Paz, entre otros.

En algunas regiones, se ha dinamizado la instalación de oficinas regionales con el ánimo de mejorar los niveles de coordinación. Estas oficinas generalmente están coordinadas por comités regionales. Adicionalmente, la organización se estructura en torno a nodos departamentales y locales. Todas las expresiones y miembros de REDEPAZ se organizan en espacios municipales de coordinación, conocidos como Mesas Municipales de Paz de REDEPAZ. 
La organización se articula a su vez en torno a cinco áreas de $\operatorname{trabajo}^{34}$ : (a) consenso ciudadano por la paz $^{35}$; (b) defensa y protección de la población civil ${ }^{36}$; (c) territorialidad para la paz $^{37}$; (d) mujer y género ${ }^{38} ;$ y (e) administración y gestión ${ }^{39} 40$.

En su dimensión y accionar organizacional sociopolítico, REDEPAZ está conformada por las Mesas de Trabajo por la Paz, procesos regionales y locales de soberanía ciudadana constituyente, resistencia civil no violenta, iglesias, organizaciones no gubernamentales, organizaciones de jóvenes, organizaciones de mujeres, organizaciones de niños y niñas, organizaciones de derechos humanos, organizaciones de víctimas de la violencia del conflicto armado, artistas, intelectuales, académicos, voluntarios y otros espacios de trabajo por la paz.

Como estructura en red la organización articula procesos como el Movimiento Nacional de Mujeres Constructoras de Paz, el Movimiento de Niñas y Niños por la Paz, la Red de Jóvenes por el Desarme, la Coordinación Nacional de Asambleas Constituyentes Locales, el Movimiento de Madres por la Vida, las veedurías ciudadanas al proceso de reparación integral, entre otros.

En su dimensión territorial, se encuentra organizada en torno a siete regiones: "Costa Atlántica, Litoral Pacífico, Antioquia, Eje Cafetero, Centro, Santanderes y Bogotá, D.C. que

\footnotetext{
${ }^{34}$ Estas áreas coinciden con los ejes de trabajo o puntos de encuentro establecidos en la Agenda Nacional para la Paz, definida en el "Primer Congreso Nacional de Iniciativas por la Paz", celebrado en septiembre de 2005.

${ }^{35}$ Cuyo propósito es incidir en la definición de acuerdos que propendan desde la sociedad civil y el Estado por salidas no guerreristas a las varias violencias que nos atraviesan, en especial al Conflicto Armado Interno.

${ }^{36}$ Para contribuir desde el movimiento nacional de víctimas a la reconciliación, la verdad, la justicia y la reparación. Para la promoción y defensa de los Derechos Humanos y el respeto al Derecho Internacional Humanitario.

${ }^{37}$ Para consolidar los procesos de paz y las experiencias de resistencia civil pacífica y promover la construcción de capital social para la democracia y la participación a través de iniciativas de gobernabilidad local.

${ }^{38}$ Busca el reconocimiento y el respeto de los derechos de la mujer, su empoderamiento con sujeto político y el reconocimiento de sus capacidades para la construcción de la paz y la convivencia.

${ }^{39}$ Estatutos Corporación para la Paz y los Derechos Humanos REDEPAZ.

${ }^{40}$ Administra y gestiona los recursos a través de la Corporación Para la Paz y los Derechos Humanos. Ejecuta el plan prospectivo y los proyectos estratégicos.
} 
recogen las expresiones organizadas por la paz y los derechos humanos de más de 200 municipios y nodos locales de todo el país" (Redepaz, 2016, p.2).



Figura 3. Estructura Funcional de REDEPAZ ${ }^{\mathbf{4 1}}$

Para efectos de gestión del conocimiento y de recursos, REDEPAZ ha diseñado un paquete de servicios que ofrece a la sociedad colombiana, que da cuenta de su experiencia y de la sistematización de las actividades de cada área de trabajo. (Redepaz, 2016 a).

${ }^{41}$ Datos obtenidos de Redepaz (2016, p.2). 


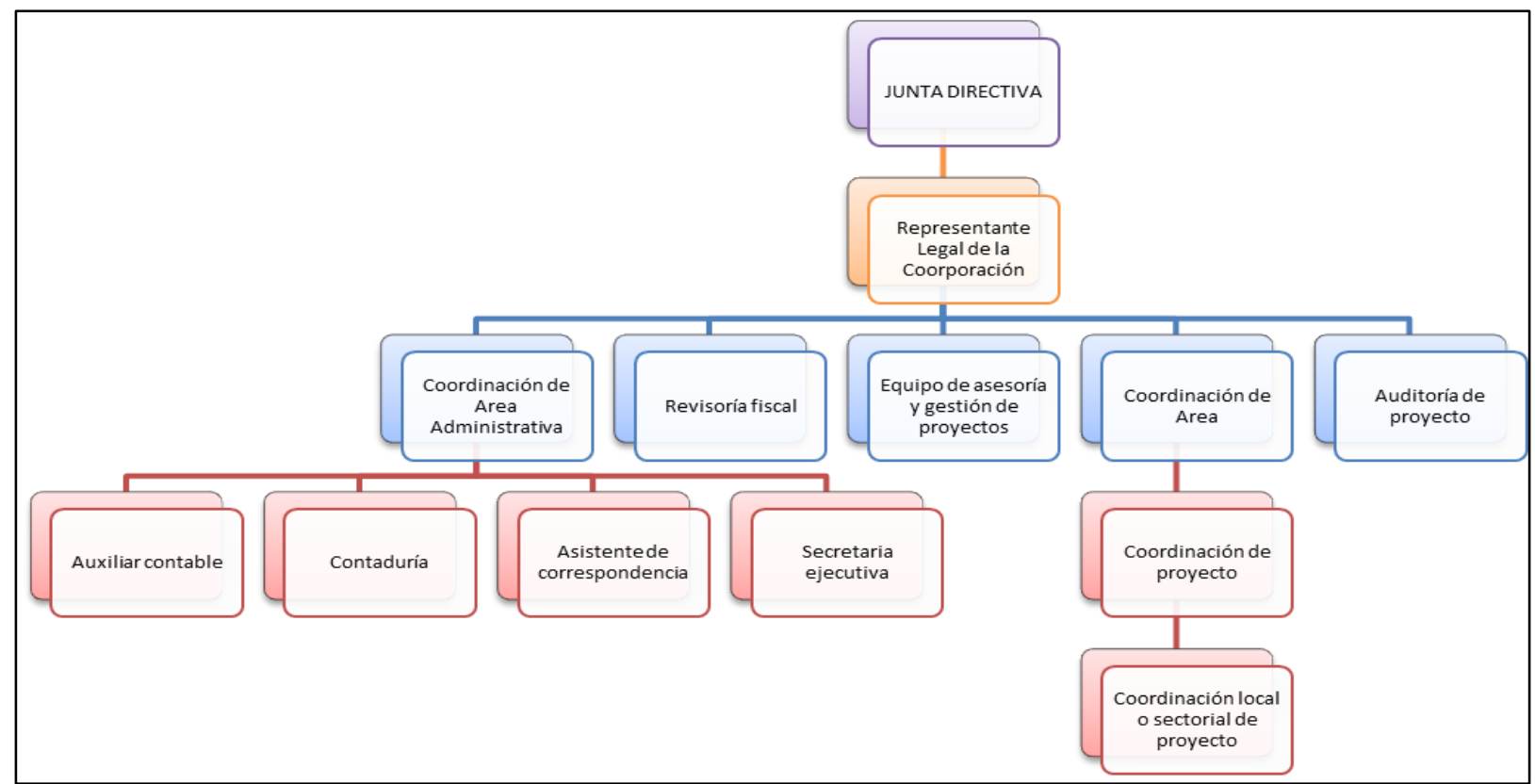

Figura 4. Estructura organizacional de REDEPAZ ${ }^{\mathbf{2}}$

\subsection{Redepaz como Sujeto Nacional de Reparación Colectiva}

El Plan Integral de Reparación Colectiva, concertado entre el Gobierno Nacional y REDEPAZ, invoca los artículos: 166, 3, 151, 152 y 168 de la Ley 1448 de 2011, los artículos 222 y 225 del Decreto 4800 de 2011 y el artículo 1 del Decreto 1725 de 2012 para señalar el daño ocasionado a REDEPAZ en los siguientes términos:

Las diferentes afectaciones y acciones de victimización a nivel local han tenido repercusión en el orden nacional. A partir del año 1997, y hasta 2010, donde hubo mayor victimización de la organización, se presenta un periodo de tiempo en el que prevalece la persecución, intimidación, retención, atentados, amenazas y asesinatos de

42 Datos obtenidos de Redepaz (2016, p.3). 
líderes, así como la estigmatización y desprestigio de la organización y la interceptación ilegal de sus comunicaciones (Redepaz, 2013, p.23).

A raíz de las actividades de incidencia política de la organización en diversas regiones del país en favor de la guerra y en contra de la paz, diferentes grupos armados ilegales consideraron a la organización como objetivo militar. En este sentido, el Plan Integral señaló que:

Existen varios municipios y departamentos en los que las actividades de REDEPAZ han cesado como consecuencia del daño. Sin embargo, su trabajo ha tenido un impacto en todo el territorio nacional, en momentos coyunturales de transición en Colombia. Bajo el fortalecimiento a la ciudadanía y la construcción de paz territorial, REDEPAZ tiene líderes y lideresas trabajando en red por todo el territorio nacional. A pesar del daño e impacto, la organización ha dejado en la sociedad colombiana una capacidad instalada de una cultura de no violencia (Redepaz, 2013, p. 23).

Las sistemáticas violaciones de los derechos humanos de los integrantes de la organización, materializadas en homicidios, atentados, intimidación y amenazas contra sus miembros, impactaron profundamente a nivel personal y colectivo en lo nacional, regional, departamental, municipal y local. Al respecto el Plan señaló:

Los asesinatos, los atentados, la intimidación y amenazas continuadas a líderes y activistas vinculados con la organización han tenido y tienen impacto a nivel personal y colectivo. Al igual que con las amenazas y las intimidaciones, el mayor de los daños 
ocasionados por los asesinatos fue la ruptura de procesos en el territorio y el cierre de las oficinas de REDEPAZ en las regiones. Sus integrantes viven una constante presión psicosocial por el inminente riesgo a su integridad personal y la de sus familias. De otro lado, la falta de respuesta efectiva de las autoridades ha generado relaciones de desconfianza entre los activistas y las instituciones. A nivel colectivo, estos tipos de victimización tienen efecto en cuanto han contribuido a la desarticulación de los grupos o la desmotivación para continuar, pues con la agresión se reduce la capacidad de ser y hacer. La presión que ejercen diferentes actores armados y en algunos casos los representantes del gobierno local, regional y nacional a los miembros de REDEPAZ continúa siendo un obstáculo para el desarrollo de las actividades. Varios de los procesos que REDEPAZ venía adelantando tuvieron que suspenderse debido a los temores colectivos sobre la posibilidad de asesinatos y atentados. Adicionalmente, esto tuvo un impacto en las relaciones de REDEPAZ con las comunidades en el territorio.

En algunos casos, los integrantes de los colectivos se han visto en la necesidad de negar la pertenencia a la organización o huir. Igualmente, en algunas regiones los miembros de la organización han tenido que trabajar a escondidas, como es el caso de Montes de María, Norte del Valle, Antioquia, Chocó y Santanderes. También debido a las amenazas sistemáticas, se suspendieron los trabajos de REDEPAZ en Yarumal con niños, niñas y adolescentes. En ocasiones, las mesas de trabajo desaparecieron del escenario local o están desactivadas, como son los casos de Cesar, Tibú, Mogotes y Charalá (Riachuelo), donde el proceso sigue siendo torpedeado por toda clase de señalamientos y amenazas (Redepaz, 2013, p. 39). 
La información sobre las violaciones de los derechos tanto individuales como colectivas en la organización sigue siendo incompleta y parcial, a la fecha la organización se encuentra en un proceso de captura, procesamiento, sistematización y evaluación de la información, la organización has sido frecuentemente objeto de estigmatización por parte de líderes políticos, instituciones del Estado, fuerzas armadas legales e ilegales, siendo casos emblemáticos el proceso de Mogotes y Montes de María. Las persecuciones, amenazas e intimidación han sido una constante desde su creación algunos casos son los procesos de Montes de María y Yarumal, en el departamento de Antioquia, que han llevado a la suspensión del trabajo de REDEPAZ EN las regiones. De la misma manera, se han presentado casos concretos de homicidios que han conducido a su vez al cierre definitivo de sus oficinas y actividades, los homicidios de Amparo Jiménez en Valledupar el 11 de agosto de 1998, Tirso Vélez Vélez, exalcalde de Tibú y aspirante a la gobernación de Norte de Santander el 4 de junio de 2003, y Judith Adriana Vergara Correa, directora del proyecto "juventud constructora de paz" en la ciudad de Medellín con la comuna 13, el 25 de abril de 2007. Como consecuencia de las amenazas y persecución, algunos de sus miembros han recurrido al refugio en otros países como son los casos de Ana Teresa Bernal, Joaquín Mayorga y Héctor Consuegra. Igualmente, la organización y sus miembros han sido objeto de atentados a la vida e integridad personal especialmente en Bogotá, la interceptación de sus comunicaciones, en Bogotá y Bolívar a través de operaciones como la denominada Risaralda por parte del extinto DAS. (Sanabria, 2017 a).

El Plan Integral de Reparación Colectiva, estableció el daño como: 
i) Daño Organizacional, reflejado en el cambio en los modelos y relaciones de liderazgo y vocerías; afectaciones en la estructura para la toma de decisiones; cambio en las formas de resolución de conflictos; pérdida de autonomía; afectación en las Comunicaciones; afectación en la Identidad Organizativa; ii) Daño Político, se evidencia a través de la reducción de la zona de influencia, debilitamiento del reconocimiento público y aceptación de la organización; rompimiento y debilitamiento de Redes sociales de la organización (relaciones con organizaciones sociales y el Estado) y en la pérdida de incidencia política; iii) Daño Económico, se ve afectado el plan de vida de la organización; disminuyen los recursos, la capacidad de gestión y la sostenibilidad; y, iv) Daño psicosocial, se evidencia a través de hallazgos como el miedo, la negación, la paralización de las acciones, la decisión de huir o de retirarse de la organización (UARIV, 2016, p.22).

\subsection{EI Proceso de Reparación Colectiva de REDEPAZ}

El procedimiento que se ha seguido para la reparación colectiva está definido en el Plan Integral de Reparación Colectiva (PIRC) en los siguientes términos:

\subsubsection{Fase de acercamiento.}

Desde julio de 2013, la Unidad para las Víctimas inició el acercamiento a REDEPAZ, mediante la convocatoria a una reunión con 12 miembros del comité de coordinación de REDEPAZ, los cuales provienen de diferentes regiones del país. En este espacio se conformó un Comité de Impulso provisional. Posteriormente, en el mes de agosto, se realizó la primera 
reunión del Comité de Impulso con el propósito de construir una agenda de trabajo conjunta que permitiera implementar acciones durante los siguientes meses (Redepaz, 2017).

Dos meses después, en octubre, se realizó un encuentro nacional que contó con la participación de 80 miembros activos de REDEPAZ y de algunos fundadores. En el evento se socializaron los avances del proceso y se identificaron expectativas en materia de memoria histórica, medidas de satisfacción, atención psicosocial, garantías de no repetición y reparación transformadora. Además, se amplió la participación de miembros en el Comité de Impulso, el que pasó a estar conformado por 28 personas. El encuentro contó con la presencia de funcionarios del Ministerio de Salud, UNP y de la Alcaldía de Medellín (Redepaz, 2016 b).

El Comité de Impulso está constituido por personas representativas del Sujeto de Reparación Colectiva y es responsable de impulsar el proceso y de la interlocución con la Unidad para las Víctimas bajo los principios establecidos en la Ley 1448 de 2011, los decretos reglamentarios de dicha ley y el Protocolo de Participación de las Víctimas. Debe garantizar que los distintos liderazgos y los sujetos de especial protección encuentren representación en este espacio (UARIV, 2013).

El grupo de trabajo estable del Comité de Impulso adopta sus decisiones en representación de la Red y con base en ejercicios democráticos que buscan incidir en la definición de acuerdos por consensos, que propendan por la resolución pacífica de conflictos.

Al respecto, uno de sus presidentes colegiados señala: "en nuestra apuesta de paz y justicia 
social, la democracia no es solamente un medio, un método o una estrategia, la democracia es el proceso y un fin en sí mismos. Concebimos el proceso como un todo integral e integrador...” (Sanabria, 2014, p. 55).

Luego de ampliar el Comité de Impulso REDEPAZ estableció una metodología de trabajo en torno a los siguientes propósitos:

i) fortalecer los alcances de los planes de reparación colectivos, previamente elaborados y aprobados; ii) lograr el empoderamiento ciudadano de las víctimas y sus organizaciones que oriente las costumbres políticas hacia nuevos modelos de territorialidad; iii) mantener la autonomía ciudadana en los nuevos territorios y propiciar la articulación y coordinación con gobiernos locales que serán elegidos en Octubre de 2015; iv) fortalecer la autonomía ciudadana frente a las nuevas situaciones dentro del marco de la Ley; v) propiciar en el corto y mediano plazo pactos sociales y mandatos para el desarrollo humano integral autosostenible, dibujados como proyectos de vida feliz y en armonía, que permitan avanzar hacia un horizonte de reconciliación, perdón y transformación, en defensa de la vida y los derechos humanos; y, vi) avanzar en el marco de los preacuerdos logrados en la mesa de conversaciones GobiernoFARC, en especial en referencia al punto de la agenda sobre víctimas (10 principios, Comisión de la verdad, desminado, etc.), en la Construcción de Territorialidad para la Paz (Redepaz, 2013, p. 33).

La metodología le permitió a REDEPAZ construir un modelo transformador propio para el 
abordaje de la reparación colectiva, lo que lo impulsó a desarrollar el proyecto "Fortalecimiento a los Comités de Impulso de la Reparación Colectiva" en cuatro regiones del país. El enfoque transformador de REDEPAZ hace imprescindible el involucramiento de todos los sujetos objeto de la reparación colectiva y de aquellos que han asumido el liderazgo y acompañamiento. Estos últimos se convierten en socios estratégicos y promotores de participación en el proceso y de toda la comunidad que hace parte del colectivo.

La premisa de REDEPAZ en el fortalecimiento del Comité de Impulso es que: "Al empoderarlos políticamente están en condiciones de participar e incidir en la implementación de los planes de reparación colectivos y de incluir mediante la gestión pública, los planes de reparación colectiva, como componentes sustanciales de los planes de desarrollo locales" (Redepaz, 2014, p.33).

Con base en la extensa experiencia en el campo de la participación social y política, y en la construcción de modelos propios de abordaje de grupos humanos diversos, REDEPAZ ha logrado construir metodologías propias para el abordaje de procesos de formación, capacitación y empoderamiento social, entre otros. La metodología se estructura bajo el denominado "acto creativo" ${ }^{43}$, un método que consiste en generar conocimiento a través de la acción. La propuesta pedagógica, en sincronía con la investigación acción participativa, la cartografía social o la etnografía introduce una mirada holística de la reparación colectiva al proporcionar una comprensión de la especificidad de los territorios, nodos de REDEPAZ.

\footnotetext{
${ }^{43}$ Formación y Fortalecimiento de los Comités de Impulso Programa de Reparación Colectiva
} 
Al respecto, uno de los integrantes de la organización señala: “El Comité de Impulso es el núcleo de personas que tienen el mapa de la Red, son elementos de memoria antes, durante y posterior a los hechos victimizantes $\mathrm{y}$, por ende, son personas que pueden proyectar con mayor incidencia a la organización” (Mesa, 2016, p. 2).

Por lo anterior, los integrantes del Comité realizan un aporte cualitativo y dan valor agregado al desarrollo de la reparación, vista como un conjunto de relaciones o escenarios, donde los participantes desarrollan su vida a partir de lo sensible, de los movimientos culturales, la resistencia, los imaginarios colectivos, las narrativas y la cotidianidad (Redepaz, 2017).

\subsubsection{Fase de registro}

En el mes de agosto de 2013, la Unidad para las Víctimas realizó la diligencia de declaración a REDEPAZ, a través de la cual se emitió en el mes de octubre el Acto Administrativo de Inclusión de REDEPAZ como Sujeto de Reparación Colectiva, a través de la Resolución No. 2013-277428 de 7 de octubre de 2013, FSC-GH000000042.

\subsubsection{Alistamiento}

La fase de alistamiento para la reparación colectiva de REDEPAZ se inició en marzo de 2014, luego de una reunión de planeación con la presidencia colegiada y la Unidad para las Víctimas, donde se decidió abordarla a partir de cuatro ejes temáticos que se desarrollarían a través de encuentros regionales sobre: Medidas de Satisfacción (Bucaramanga, 26 y 27 de marzo 
de 2014). Enfoque Psicosocial (Santa Marta, 24 y 25 de abril de 2014). Comunicaciones (Medellín, 5 y 6 de mayo de 2014). Garantías de no repetición (Bogotá, 5 y 6 de julio de 2014). Para cada uno de estos encuentros fueron convocadas las DT y entidades del Estado identificadas por el Sistema (Redepaz, 2017).

\subsubsection{Diagnóstico del daño}

Luego de surtida la fase de alistamiento en la que se recogieron insumos importantes para el diagnóstico, se acordó realizar el encuentro nacional del diagnóstico del daño a la organización. Este encuentro, igual que los anteriores, requirió de jornadas preparatorias de trabajo, que incluyeron una alianza estratégica con la Universidad Javeriana, que tendría como misión la construcción tripartita (Unidad-REDEPAZ - Universidad Javeriana) del concepto de Memoria Transformadora, identificada por REDEPAZ, como un componente transversal al proceso de reparación colectiva. Además de constituirse en un aporte a la construcción de una política pública de paz en Colombia. El evento se llevó a cabo en el mes de noviembre de 2014, en donde se abordaron temáticas específicas como: cartografía de REDEPAZ, memoria transformadora y focos de observación del daño psicosocial (Redepaz, 2017).

\subsubsection{Fase Formulación y aprobación del Plan de Reparación Colectiva}

Con el objeto de validar el Diagnóstico del Daño y el Plan Integral de Reparación Colectiva (PIRC), el 22 y 23 de diciembre de 2014 fueron convocados el Comité de Impulso y las

entidades del Estado: Ministerio del interior, Unidad Nacional de Protección, Agencia 
Colombiana para la Reintegración y la Fiscalía General de la Nación. La única entidad que no asistió fue la Unidad Nacional de Protección (Redepaz, 2013).

\subsection{Análisis de la Oferta, Invitación y/o Demanda de la Reparación Colectiva}

De acuerdo con lo dispuesto en la Ley 1448 de 2011 y el Decreto 4800 de 2011, según la modalidad de identificación que adopte la Unidad para las Víctimas, el proceso de registro de sujetos de reparación colectiva puede seguir dos vías, a saber:

En la modalidad por oferta, la Unidad para las Víctimas identifica los sujetos colectivos victimizados a quienes se les expresa la voluntad del Estado de que participen en el Programa de Reparación Colectiva y, en caso de que estos acepten la invitación, la Unidad coadyuvará en las solicitudes de registro. En la modalidad por demanda, los sujetos de reparación colectiva no incluidos en la oferta del Estado realizarán el procedimiento de registro ante el Ministerio Público.

REDEPAZ inició su proceso de Reparación Colectiva bajo de la modalidad de oferta, es decir, el Estado identificó inicialmente a la red como un sujeto colectivo al que le fueron vulnerados los derechos y donde se presentaron graves afectaciones al tejido social.

La repercusión del daño no solo se dio a nivel interno, sino que afectó el proceso de incidencia nacional. En este sentido, las acciones de REDEPAZ empezaron a debilitarse, como la Semana por la Paz, que se inició en la Red en 1993, pues perdió fuerza durante los años más 
álgidos del conflicto armado. No obstante, a pesar de la caracterización de la Unidad para las Víctimas para ofertar la reparación, la identificación fue un tanto subjetiva, dado que simplemente se dejó en potestad del Estado la decisión de quién ingresaba como sujeto.

Ante la insuficiencia de mecanismos efectivos que dieran mayor amplitud y reconocimiento a las víctimas para la reparación, se abrió la modalidad por demanda. Decreto 4800 (2011), en su articulo 227. Esto amplió el número de sujetos solicitantes y, por supuesto, la ficha de registros. Se evidenció un aumento significativo en los sujetos a reparar. Los registros, el análisis y la evaluación de las solicitudes demandaron a los profesionales de la UARIV evaluar y decidir, según criterios de registro, quién accedía y quién no. 


\section{Medidas de Reparación Colectiva establecidas en el Plan Integral de Reparación Colectiva de REDEPAZ}

\subsection{Fundamentos conceptuales, éticos y políticos de la Reparación Colectiva de REDEPAZ}

La perspectiva de análisis que se desarrolla a continuación parte de los documentos elaborados por la propia organización en colaboración con la Unidad Nacional de Víctimas y la Pontificia Universidad Javeriana. El Plan de Reparación REDEPAZ fue construido siguiendo los estándares nacionales e internacionales existentes en la materia, a través de la articulación de un modelo de reparación integral a un sujeto de carácter colectivo. Por esta razón, dentro de las medidas adoptadas no se incluye la indemnización de los daños ocasionados tanto individual como colectivamente por los diferentes hechos victimizantes de los cuales fueron objeto sus miembros y el colectivo (Redepaz, 2013).

La reparación integral tiene como sustrato o base el fortalecimiento estructural de la organización, el cual se materializa en las diferentes modalidades de reparación: rehabilitación, satisfacción y no repetición; así como la reparación de sus símbolos, imaginarios y prácticas pedagógicas y metodológicas en relación con la cultura de paz; sus objetivos misionales e incidencia política tanto en lo territorial como en lo nacional en la cultura de la autoprotección y del autocuidado; también, la incorporación de un modelo que brinde una visión propia frente a la memoria histórica como de la memoria transformadora (Redepaz, 2013).

El mayor aporte de este modelo de reparación está en su enfoque denominado "memoria 
transformadora", por sus sólidos fundamentos conceptuales, éticos y políticos, que a la vez aborda no solo las iniciativas de la organización, sino también, el proceso como aporte para el desarrollo de una política pública para la paz. "El proceso de reparación colectiva de REDEPAZ ha desencadenado la necesidad de desarrollar instrumentos y metodologías que trasciendan la Red y se conviertan en un instrumento que tenga incidencia en otros grupos y organizaciones y la sociedad en su conjunto" (Redepaz, 2017 b).

Con frecuencia, la reparación se basa en el restablecimiento de la situación inmediatamente anterior a la violación de derechos humanos; sin embargo, si la situación anterior se presentaba como una realidad negativa para las víctimas, entonces se vuelve imperativo enfocar la reparación, no hacia el regreso a la situación inicial, sino hacia la transformación de dicha situación. Esto les hace frente a las condiciones que propiciaron el conflicto en primer lugar y asiste en la generación de oportunidades para los familiares y las víctimas (Beristain, 2010b). En este sentido, el proceso de REDEPAZ se concentra en esta dimensión transformadora por medio de la memoria transformadora.

El concepto de memoria transformadora se plantea como un eje transversal en el proceso de reparación de REDEPAZ. La noción se establece como eje articulador de una ruta conceptual y metodológica mayor en la que pueden converger y nutrirse otros sujetos de reparación colectiva y otros procesos de memoria en el país, que le apuestan decididamente a transitar de las memorias de la guerra a las memorias de la paz. Noción, dentro la perspectiva de una memoria alternativa, en paralelo a las diferentes perspectivas de memoria, como la histórica o institucional, que han emergido en Colombia desde la apropiación de marcos y paradigmas de la 
justica transicional (Redepaz, 2017 c).

Adicionalmente, se nutre de una multiplicidad de matices que han surgido de las prácticas de una diversidad de colectivos organizados y como experiencia social emancipatoria, amplia plataforma de debate para transmutar lo privado e incomunicable durante mucho tiempo, en algo público y sociable para las organizaciones. Mecanismo de defensa de la vida, dispositivo de resistencia comunitaria, horizonte político de nuevas formas de ser y hacer ciudadanía en el espacio público, expresión de denuncia de lo ocurrido, referente para la movilización de demandas de justicia y reparación, expresión de las prácticas, saberes, posibilidad para la soberanía organizativa para amplificar capacidades investigativas propias (la construcción de archivos organizativos, de DDHH, etc.) (Redepaz, 2017 c).

La organización conceptúa la idea de memoria transformadora como:

un concepto de frontera, un saber actuante y una práctica pedagógicamente abierta y dinámica. [...] Se asume que esta noción es central para el desarrollo de escenarios posibles de construcción de paz, en el marco de una transición no violenta y de concepciones críticas sobre el pasado, el presente y el futuro. La memoria transformadora también reconoce el carácter político de la memoria, así como sus dimensiones históricas, institucionales, sociales, culturales, éticas y emocionales... (Redepaz, 2017 c, p.11).

Con estas bases conceptuales, REDEPAZ transita por unas memorias centradas en hechos de victimización para dar respuesta a unas memorias enfocadas en tejidos de vida. En este sentido, la noción de memoria transformadora permite concebir el recuerdo no solo como un dispositivo 
de evocación de hechos victimizantes, sino como un acto político, experiencial y de transformación. Importa reconstruir el pasado (lo que sucedió), pero también tejer la vida de la organización de cara a los procesos presentes y futuros para comprenderlos y apropiarlos cultural y socialmente. Con el concepto de memoria transformadora, queda más explícito el principio de que "la experiencia no es lo que le pasa a uno, sino lo que uno hace con lo que le pasa" (Redepaz, 2017 c).

A partir de lo anterior, como sujeto de reparación colectiva, en el marco de la Ley de Víctimas y Restitución de Tierras de 2011, REDEPAZ ha planteado el desarrollo del concepto de memoria transformadora como un instrumento conceptual, metodológico y ético-político, que se basa en las siguientes premisas orientadoras de todo el plan de reparación (Redepaz, 2017 c):

1. El concepto de memoria transformadora debe permitirle a REDEPAZ no repararse para volver a ser lo que era, sino reparase para seguir tejiendo su condición de actor político y social constructor de paz con la conciencia de enfrentar los retos que tiene el país de hoy, a propósito del nuevo marco de oportunidad político que se vislumbra la firma de la paz con las insurgencias.

2. El concepto de memoria transformadora ayudará a REDEPAZ a tejer no solo una memoria hacia dentro como organización, sino una memoria hacia fuera como actor político transformador de realidades y contextos.

3. La noción de memoria transformadora concebida como un acto político de 
transformación implicará que REDEPAZ reconozca los acumulados de trabajo de la organización durante 25 años de existencia. Ayudará a posicionar en la escena pública a REDEPAZ como un colectivo sentipensante, como una red de afectos, que a lo largo de estos años ha apostado por la construcción de tejidos de paz y de ciudadanía en las regiones y a nivel nacional con presencia en cerca de 500 municipios.

4. La noción permitirá reconocer en la esfera pública los acumulados de trabajo de la organización en términos de tejidos de paz que pueden ayudar a potenciar la construcción de un nuevo país. Entre estos acumulados se encuentran las iniciativas de trabajo locales, las mesas por la paz, las semanas por la paz, las comunidades de paz, las constituyentes locales, las asambleas, los mandatos, los pactos por la paz.

5. El concepto ayudará a posicionar en la escena pública la gran experiencia de REDEPAZ en la construcción de unas políticas, pedagogías y entramados simbólicos por la paz, que revelan el proyecto de país de la organización y la diversidad de proyectos de vida que lo respaldan.

6. El concepto de memoria transformadora mostrará que REDEPAZ le apuesta a un ejercicio para constituir sujetos de derechos para sedimentar condiciones de soberanía y de participación en profundidad en la sociedad colombiana. El principal objetivo en esta dirección es avanzar en la consolidación del movimiento social por la Paz en Colombia. La noción de "constituir" la asume la organización en el sentido de posibilitar y recrear los procesos de emergencia de sujetos políticos en diversos escenarios, tomando en 
consideración también las múltiples tensiones creativas que implica el trabajo con estos sujetos (mujeres, NNA o adultos).

7. Finalmente, a través de esta noción, REDEPAZ buscará que en el país se reconozca la centralidad del proceso constituyente de 1991, así como de los espacios de participación que emergieron a partir de este hito político para el país (Redepaz, 2017 c).

Este marco de análisis se ve reforzado por el concepto de resiliencia en grupos y colectivos, entendida como el resultado de una interacción humana, en este caso de toda una organización, que despierta aquel desarrollo potencial, propio e inherente a todo ser humano, y que busca fundamentalmente recuperar los sueños o los objetivos que le dieron origen y que son afines a todos sus asociados. Comúnmente, este concepto está relacionado con la capacidad de los sistemas (y las personas) para reaccionar y adaptarse eficazmente ante circunstancias cambiantes y desarrollar habilidades, capacidades, comportamientos y acciones con objeto de hacer frente a la adversidad. La "resiliencia" puede describirse como un proceso de adaptación que tiene lugar antes, durante y después de un acontecimiento adverso (Redepaz, 2014 b).

REDEPAZ entiende que la idea de una ciudadanía más participativa implica pensar en diversas formas de empoderar a las víctimas, para que asuman el papel de sobrevivientes responsables del presente y el futuro de la organización y del individuo, para que, en su ejercicio cotidiano, como sujetos de transformación, construyan y fortalezcan nuevos escenarios y mecanismos para ejercer sus derechos. 
En tal sentido, la reparación colectiva identificada como retorno, reubicación, reparación organizativa local o nacional, implica que las Víctimas entren en un proceso de construcción activa y en contexto de significados y prácticas, permitiendo así un traslado desde perspectivas asociadas con un mundo ordenado y predecible a perspectivas en las que la turbulencia, la oscilación, los eventos inusuales o únicos y la innovación conforman oportunidades de comprender que el futuro está para construir, y que ese futuro está íntimamente ligado a la construcción de paz, al perdón y a la reconciliación.

Para esto es necesario que exista un conocimiento generativo y enraizado local y ecológicamente. Una conjunción de conocimientos, de saber cómo hacer y cómo ser, saber acerca de sí en contexto, saber cómo posicionarse, saber qué resulta apropiado, saber expresarse incluyendo al otro, es decir, haber superado el daño en la medida en que el colectivo se repara y recupera los sueños de vivir en condiciones de dignidad y equidad.

Estos cambios implican pensarse y promover la necesidad de nuevas formas ciudadanas, que promuevan desde espacios vitales una actitud sensible, consciente y comprometida con la vida para la construcción de una nueva realidad pacífica y armónica en pro de los derechos humanos, al avanzar hacia una actitud individual y colectiva no violenta, proactiva y soberana. Asumir compromisos colectivos de participación a través de espacios democráticos, incluyentes y propositivos que propendan por elevar los niveles de coordinación gobierno local-sociedad civil, requiere de una sociedad organizada y participativa con poder decisión y ejercitante de la democracia (Redepaz, 2017 d). 
De acuerdo con lo anterior, las modalidades de reparación propias del Plan de Reparación Integral se concentran en lo organizacional de la institución, lo que se traduce para REDEPAZ en su fortalecimiento desde un abordaje psicosocial, transformador y esperanzador de los procesos de reparación y/o reubicación de carácter colectivo. Se trata de un reto práctico y conceptual desde la diversidad y la relación entre diferentes formas de conocimiento e interacción con el mundo, que se reconocen a su vez como factores esenciales de lo humano y potencian la creatividad, el intercambio social y cultural, al enriquecer las posibilidades de adaptación e innovación desde cada uno de los acumulados históricos que encarnan las múltiples identidades individuales y colectivas.

Esta multiplicidad de modalidades involucra distintos modos de comunicarse y expresarse a nivel espiritual, corporal, de preservación del conocimiento, de resolver conflictos y de potenciar una nueva ciudadanía proactiva a partir de valores, reivindicaciones y luchas particulares, que aumente el surgimiento de escenarios de convivencia y reconciliación.

Se trata entonces de generar espacios y mecanismos de participación amplios, donde se pueda construir y potenciar apuestas comunes tanto sociales como económicas, políticas y culturales, para que los planes de reparación colectiva territoriales o territorializados (en el caso de las llamadas reparaciones nacionales), se incluyan en la planeación general del territorio, la complementen y la potencien.

De esta forma, la reparación integral y colectiva cumple dos roles importantes: (a) lograr 
que las organizaciones víctimas y sus miembros superen tal condición y; (b) promover las condiciones locales de democracia, desarrollo y seguridad que garanticen la reconciliación y la no repetición.

En este marco, el esfuerzo por hacer de la reparación colectiva una oportunidad transformadora para la paz y la reconciliación, debe enfocarse primordialmente en la consolidación de escenarios de encuentro entre las víctimas, la población considerada novíctima, las organizaciones políticas, los dinamizadores privados de la economía local, las entidades estatales y de gobierno descentralizadas o desconcentradas, etc., en los que diferentes agentes locales se reconozcan como sujetos de cambio, para activar conjuntamente pactos sociales, agendas integrales sostenibles y autónomas que les permita superar la situación presente y desarrollar las confianzas requeridas para garantizar la no repetición, en un proceso constante y ascendente de reconciliación.

Esto también implica el fortalecimiento de los procesos organizativos de las comunidades y de las organizaciones sociales y políticas a nivel local, para elevar su incidencia en la agenda pública y potenciar la apropiación de sus derechos; además de motivar una gobernabilidad local que se exprese en prácticas transparentes y equitativas de gobierno en la definición y evaluación de políticas públicas y en el trámite no violento de las diferencias (Redepaz, 2017 d).

\subsection{Estado del arte de las Medidas de Reparación Colectiva de REDEPAZ}


La reparación colectiva de REDEPAZ se estableció a través del PRIC con las siguientes medidas: restitución, satisfacción, no repetición y rehabilitación.

\subsubsection{Fortalecimiento organizativo: para hacerse efectiva se adoptaron las siguientes acciones}

En el 2015 y en los dos primeros meses de 2016, se realizaron ocho encuentros regionales: dos en la Costa Caribe (La Guajira, Magdalena y Cesar - Bolívar, Sucre y Córdoba) Antioquia, Santander, Occidente (Nariño, Valle, Cauca y Chocó) Sur (Huila, Putumayo, Caquetá, Tolima Territorios Nacionales), Viejo Caldas y Centro (Bogotá, Cundinamarca, Meta, Boyacá, Arauca y Casanare). Estos encuentros son la base del trabajo en el tema de lógica constituyente que afrontará la Asamblea Nacional y el Encuentro Nacional por la Dignidad y la Memoria de REDEPAZ de cara a la consolidación de la paz y el posconflicto. (Redepaz, 2017 d).

Estos encuentros buscaban aportar al fortalecimiento organizativo de REDEPAZ en lógica constituyente al dar cumplimiento a la primera medida de satisfacción para la reactivación política y organizativa; además, contribuir con la tercera medida de satisfacción para la recuperación de las prácticas organizativas. La finalidad de estas dos medidas es articular el trabajo ciudadano por la paz y responder de forma organizada a los retos surgidos en el marco del proceso de reparación colectiva de REDEPAZ y a la construcción de la paz como fundamento misional de la organización.

Para el cumplimiento de este propósito se plantearon los siguientes objetivos específicos (Redepaz, 2017 d): 
1. Fortalecer y articular las experiencias de territorialidad de paz y constituyentes, mediante la reflexión y proyección, al evidenciar como se construye la paz con manos ciudadanas desde las entidades territoriales y el papel de estos procesos en la agenda de paz y el posconflicto.

2. Fortalecer los mecanismos de coordinación de las iniciativas de mujeres a favor de la paz, mediante la definición de una ruta en el marco de la Resolución 1325 del Consejo de Seguridad de la ONU al acoger los acuerdos de la Habana y potenciar el papel de las mujeres en la construcción de paz.

3. Reactivar y articular el movimiento de niños y niñas por la paz, al recuperar y potenciar las diferentes propuestas didácticas y pedagógicas territoriales que permitan aportar a la construcción de una cultura de paz.

4. Recopilar, sistematizar y organizar las memorias, conclusiones y propuestas en lógica constituyente, emanadas de los ocho encuentros regionales de REDEPAZ, realizados durante el año 2015 y 2016, para que sirvan de núcleo de trabajo principal de la Asamblea Nacional de la organización.

5. Apoyar la realización de reuniones preparatorias del comité organizador de la Asamblea General para el alistamiento metodológico, político y organizativo.

Estos sectores son, entre otros: (a) Territorialidad Para la Paz, (b) Mujeres (recuperar Red de 
Mujeres Constructoras de Paz), c) Jóvenes Constructores de Paz (encuentro nacional) y d) Experiencias de trabajo con niños y niñas por la paz (Encuentro de experiencias del movimiento niños y niñas por la paz) para la construcción de pedagogías.

De otra parte, los cuatro eventos sectoriales son:

1. Territorialidad para la paz: su objetivo es fortalecer y articular las experiencias de los territorios y constituyentes, mediante la reflexión y la proyección. El papel de estos procesos en la agenda de paz y posconflicto es: (a) evaluar y analizar las dinámicas de procesos de territorialidad de paz vinculados a REDEPAZ y su incidencia en la formulación y desarrollo de políticas, planes y programas a nivel local y regional, que dinamicen la consolidación de la paz y el posacuerdo, y (b) elaborar una agenda de trabajo que dinamice procesos de formación, divulgación e implementación de los acuerdos, especialmente en las regiones donde se desarrollan estas experiencias (Redepaz, 2017 e).

2. Mujeres: el objetivo del evento fue fortalecer los mecanismos de coordinación de las iniciativas de mujeres a favor de la paz en el marco del área de mujer y género de REDEPAZ, acogiendo los acuerdos de la Habana y potenciando el papel de las mujeres en la construcción de paz. Sus objetivos específicos fueron: (a) identificar elementos de coyuntura del país y definir una ruta de incidencia desde las mujeres de REDEPAZ y (b) definir el plan de trabajo de las mujeres de REDEPAZ (Redepaz, 2017 f).

3. Jóvenes constructores de paz: este encuentro de jóvenes se realizó para fortalecer 
mecanismos de coordinación y diseñar la agenda de los jóvenes de REDEPAZ, de manera que se lograra incluir una postura estratégica en la construcción de la paz. Como objetivos específicos están : (a) hacer visible el trabajo que los y las jóvenes realizan por la paz al resaltar las experiencias de pedagogía para la paz, de desarme, prevención de la vinculación de menores al conflicto armado, poner freno a las bandas criminales y a los paramilitares, conocer sus experiencias de movilización para acceder a sus derechos y a las experiencias de interacción con el Estado y con otros sectores de la sociedad; (b) intercambiar experiencias de trabajos y metodologías que están relacionadas con la incidencia en las políticas públicas y el desarrollo de materiales didácticos; (c) generar un espacio reflexivo en torno a las identidades, imaginarios, expresiones juveniles, la interculturalidad y los enfoques diferenciales que permitan la construcción de una cultura de paz estable y duradera; (d) facilitar y promover espacios de reflexión frente a la acción comunicativa territorial, con el fin de activar procesos comunicativos que permitan difundir la construcción de una paz estable, duradera y procesos de Reconciliación; y, (e) elaborar y editar un boletín informativo virtual del encuentro. La metodología del evento se estableció en tres fases organizativas que permiten consolidar un plan de acción juvenil en la construcción de paz desde una lectura contextual, territorial y coyuntural, obedeciendo a las dinámicas socioculturales del territorio y del país (Redepaz, 2017 g).

\section{Experiencias de trabajo con niños y niñas por la paz para la construcción de pedagogías:} esta medida de reparación tiene por objetivo reactivar y articular el movimiento de niños y niñas por la paz para recuperar y potenciar diferentes propuestas didácticas y pedagógicas territoriales que permitan aportar a la construcción de una cultura de paz. Son sus objetivos específicos: (a) visibilizar las experiencias, procesos y aportes pedagógicos en la construcción de una cultura de 
paz, y (b) aportar elementos pedagógicos, metodológicos y didácticos a la cultura de paz y no violencia. La metodología de trabajo abordada da cuenta de dos momentos: (a) la historia del movimiento de niños y niñas por la paz y los retos ante la coyuntura nacional de la firma de los acuerdos de paz de la Habana y la conferencia sobre educación para paz; y (b) la presentación de las experiencias de trabajo con niños y niñas que se realizan en las regiones agrupadas en educación formal y no formal.

El encuentro se cerró con un acto simbólico en el que se entregó el símbolo que acredita a cada participante como constructor de paz e impulsor del movimiento de los niños y niñas por la paz. (Redepaz, 2017 h).

\subsubsection{Semana por la Paz 2015}

La organización, lanzamiento y realización de la Semana por la Paz 2015, cuyo lema fue "Yo saludo", mantuvo la vinculación y participación de muchas organizaciones, tanto a nivel nacional como en lo local. Como en otras oportunidades el tema económico fue relevante, porque pese a las gestiones no se logró financiación directa para el evento. Sin embargo, se llevaron a cabo importantes eventos culturales, pedagógicos y de incidencia política. Se realizaron en todo el territorio nacional 1500 actividades por la paz. Se destaca la realización de foros, seminarios y encuentros pedagógicos del acuerdo de paz Gobierno-FARC-EP (Redepaz, 2015).

\subsubsection{Diseño de una estrategia de comunicación}


Se fortaleció la imagen corporativa con varios elementos y piezas comunicativas: logo símbolo, página web, pendones, plataforma Moodle y pedagogía de los acuerdos. Se destaca la inscripción y realización del curso virtual "Es la Hora de la Paz", que benefició de forma gratuita a 700 personas en el curso de 2015 (Redepaz, 2015).

REDEPAZ logró la reestructuración de su página $w^{4} b^{44}$, dado que se ha convertido en un importante instrumento de divulgación de información y pedagogía para la paz, a través del cual no solamente se da cuenta de las actividades realizadas a nivel nacional y regional, sino que estimula la deliberación y la reflexión.

\subsubsection{Semana por la paz 2016}

Del 4 al 11 de septiembre se desarrolló la Semana por la Paz 2016, bajo el lema "Reconciliémonos de corazón". Se mantuvo la vinculación y participación de muchas organizaciones, tanto del nivel nacional como local. Para algunos eventos especiales en las regiones se contó con apoyo directo del operador logístico de la UARIV. Las organizaciones socias de la Semana por la Paz realizaron actividades y gestionaron apoyos puntuales. Se destaca el "Encuentro Nacional de Pedagogía por la Paz", realizado en la Universidad Javeriana, donde se beneficiaron varios integrantes de la región centro de REDEPAZ. Pese a que no se lograron mayores recursos económicos directos, se llevaron a cabo importantes eventos culturales, pedagógicos y de incidencia política, lo que incluye más de 1.800 actividades por la paz en el

\footnotetext{
${ }^{44}$ www.REDEPAZ.org.co
} 
marco de la semana por la paz en todo el territorio nacional; además de foros, seminarios y encuentros pedagógicos del acuerdo de paz Gobierno-FARC-EP (Redepaz, 2016 c).

\subsubsection{Recuperación de prácticas organizativas, a través de las siguientes acciones}

Se realizó la Asamblea Nacional de REDEPAZ en la ciudad de Bogotá del 2 al 4 de diciembre de 2017. Dos fueron sus objetivos: (a) facilitar el acceso y la visibilidad de los resultados del análisis participativo de contexto político y social que se desarrollará al interior de la Asamblea y permitir concertar los lineamientos pedagógicos, organizativos, comunicacionales y políticos de la Red y el papel que esta debe desempeñar en un escenario de construcción de paz sin actores armados ilegales; (b) facilitar el acceso y la visibilidad de la planeación prospectiva de REDEPAZ al 2030, evidenciando los resultados de la identificación colectiva de los elementos centrales del plan de acción, organizativo, comunicacional y pedagógico a nivel nacional y territorial; y, (c) facilitar el acceso y la visibilidad de los resultados de lo acordado conjuntamente, en relación a la estructura organizativa y jurídica de la red en todos los niveles (local, departamental, regional y nacional). (Redepaz, 2017 i).

Para el desarrollo de la Asamblea, se plantearon las siguientes actividades: (a) socialización de experiencias en la construcción de paz; (b) construcción y definición de las líneas de acción política para la consolidación de una paz estable y duradera en mesas temáticas; (c) discusión y construcción en comisiones de los ejes de trabajo de REDEPAZ para la construcción de la paz duradera y estable; (d) definición de ejes temáticos de la RED desde la región; y, (e) elección de sus copresidentes, representantes sectoriales, representantes regionales y coordinadores 
departamentales.

\subsubsection{Memoria transformadora}

Consistió en la construcción teórica, ética y política del concepto de memoria transformadora como eje transversal al proceso de reparación colectiva, del cual se extrajeron los insumos ya anotados. Para ello se establecieron las siguientes acciones:

Diseñar e implementar una estrategia pedagógica para la socialización del concepto de memoria transformadora, cuyo alcance radicó en coordinar la interacción de los sujetos nacionales y territoriales de reparación colectiva reconocidos por la Unidad Nacional de Víctimas, e incidir en la implementación del programa administrativo de esa reparación colectiva a cargo de la mencionada Unidad Nacional de Víctimas.

El objetivo general de la actividad consistió en fortalecer la coordinación nacional de sujetos de reparación colectiva, al generar un proceso organizativo sostenible para el enlace de acciones tendientes a lograr un mayor impacto e incidencia política, que les permitiera mejorar la implementación de sus planes de reparación y aportar a la construcción de la paz y a la reconciliación nacional. Objetivos específicos (a) elaborar participativamente un documento que recogerá la propuesta de ajuste al programa de reparación colectiva desde la perspectiva de los sujetos nacionales; (b) definir la ruta de incidencia en la reglamentación de programa de reparación colectiva en el marco de la implementación de los acuerdos de paz y construir un 
mecanismo de incidencia para la superación de los "cuellos de botella" existentes en la ruta de reparación de sujetos nacionales; (c) constituir un espacio de seguimiento y veeduría a la implementación de los planes nacionales de reparación colectiva; (d) establecer una estrategia de incidencia e interlocución con la Unidad de Víctimas para la implementación efectiva de lo establecido en el punto 5.1.3.3.3 del acuerdo de paz firmado entre el Gobierno y las FARC, en lo referente a los planes nacionales de reparación colectiva; y, (e) construir un documento de propuestas para la elaboración del Plan Especial de Reparaciones establecido en el punto 5.1.3.3.3 de los acuerdos de paz.

La acción aquí propuesta busca aportar a la implementación de un enfoque de reparación colectiva que promueva las transformaciones que la construcción de la paz, la convivencia y la reconciliación demandan, con el propósito de obtener los más altos niveles de verdad, justicia y reparación (Redepaz, 2017 j).

Abordar un enfoque transformador de reparación colectiva, implica reconocer fundamentalmente que, en todas las acciones a desarrollar, son los sujetos colectivos con sus fortalezas individuales, quienes están llamados a asumirse como sujetos capaces de construir nuevas realidades, de autorepararse para la paz y la vida y de recuperar los sueños colectivos e individuales con dignidad y compromiso.

Allí entran en juego elementos importantes como la recuperación de la memoria con enfoque transformador o memoria transformadora, el abordaje psicosocial para fortalecer organizativa y políticamente a los sujetos colectivos de reparación y un empoderamiento político 
y económico que promueva más y mejores formas de participación y acción ciudadana para el desarrollo sostenible y la convivencia. En ese sentido, esta propuesta tendrá un fuerte componente de fortalecimiento de las capacidades de planeación prospectiva para la paz y el desarrollo humano.

Cuando asumimos el enfoque transformador como elemento sustancial de la reparación colectiva, se hace imprescindible el involucramiento de todos los sujetos que hacen parte del colectivo sujeto de la reparación, lo que nos obliga en primera instancia a involucrar a aquellas personas que han asumido las tareas de liderazgo y acompañamiento para convertirlos en socios estratégicos del enfoque y desde ellos promover la participación de toda la comunidad que pertenece o hace parte del colectivo. Lo que pretendemos al implementar el enfoque transformador, es trascender el plano individual e individualizado de la reparación para mejorar los impactos positivos en la reconstrucción de toda la sociedad y en la transformación de realidades adversas a la paz y la vida.

\subsection{Reflexiones finales sobre la Reparación Colectiva de REDEPAZ}

Las Leyes 975 de 2005 y 1448 de 2011, mencionadas a lo largo del documento, así como sus decretos reglamentarios, retoman en gran medida los estándares del derecho internacional de los derechos humanos, un esfuerzo promovido por las diferentes fuerzas sociales, políticas e institucionales que participaron en los debates previos a su promulgación, entre ellas REDEPAZ. El conjunto de medidas de reparación colectiva formuladas a través del Plan Integral de Reparación Colectiva (PIRC) entre la Unidad de Víctimas del Gobierno y REDEPAZ retoman 
dichos estándares nacionales e internacionales e, incluso, van más allá al formular el concepto de "memoria histórica transformadora". Así, cada una de las medidas adoptadas de reparación de Redepaz (restitución, satisfacción, rehabilitación y no repetición), se fundamentan en los estándares internacionales de derechos humanos en la materia, aplicados a la reparación colectiva como tal.

Es importante indicar que por tratarse de una organización social las medidas adoptadas están orientadas básicamente a la reparación integral como grupo y no a sus integrantes individualmente considerados, de allí que cada una de las medidas busquen el resarcimiento del daño ocasionado al grupo considerado en su identidad propia. El considerar la organización como víctima colectiva surge de la consideración del impacto del conflicto sobre la organización como un conjunto, más allá del interés de agrupar varias víctimas individuales bajo una misma figura legal. Las medidas de restitución en el presente caso buscan fundamentalmente facilitar a la organización su fortalecimiento organizativo, con su reactivación política, la dotación de instrumentos y recursos financieros, técnicos y humanos para su funcionamiento; además, el fortalecimiento de sus sistemas de comunicación, estrategias de formación y medidas en materia de administración de justicia para la prevención de nuevas violaciones con el desmantelamiento de las causas que dieron origen a la victimización.

Las medidas de satisfacción buscan fundamentalmente, como se mencionó previamente, la recuperación simbólica de su actividad a lo largo y ancho del país, la cual fue deslegitimada por la acción del Estado colombiano mediante la recuperación de sus prácticas organizativas, la legitimación de sus acciones de paz, la reivindicación de sus símbolos, reconstrucción de 
archivos y de su memoria histórica. Las medidas de no repetición son orientadas básicamente a la prevención de nuevas violaciones graves de derechos humanos en contra de la organización, especialmente, en los territorios donde han desarrollado su actividad y en aquellos en los que fueron despojados de sus derechos con acciones en materia de administración de justicia, reconciliación social, iniciativas de política pública y planes de prevención territorial. Esta última medida se complementa con las medidas de rehabilitación las cuales consistieron en iniciativas de construcción de planes territoriales, reconstrucción del tejido social y mecanismos de autoprotección individual y colectiva.

Este conjunto de medidas adoptadas concertadamente entre el Gobierno Nacional, representada a través de la Unidad de Víctimas, y la organización fueron establecidas teniendo en cuenta su eficacia y pertinencia frente a la victimización, los daños causados, las necesidades de la organización y los estándares existentes en la materia.

Las medidas de restitución fueron diseñadas para la reactivación política y organizativa adoptando metodológicamente sus prácticas organizativas, usos y formas de organización participativa, la reactivación de las acciones que la han caracterizado como organización social, especialmente, con el fortalecimiento territorial y nacional de la llamada "Semana por la Paz", referente nacional en materia de la reivindicación del derecho a la paz y sus acciones simbólicas comunicativas a lo largo del territorio nacional.

Igualmente, estas medidas fueron orientadas a la recuperación de sus estructuras organizativas diezmadas por la victimización de sus miembros por parte de actores armados con 
acciones de infraestructura para la paz. Las medidas de satisfacción fueron diseñadas para que el Estado colombiano dignificara la acción de REDEPAZ como organización constructora de cultura de paz en los diferentes territorios del país, como acción igualmente de reconciliación simbólica y cultural. Esto implicaba necesariamente su legitimación como organización y la recuperación de sus prácticas organizativas, mediante el fortalecimiento de iniciativas democráticas territoriales de pedagogía para la paz y la convivencia, la recuperación de su memoria, de sus archivos físicos y simbólicos, de sus hitos y sus aportes a la cultura de paz y convivencia en el país, en vía de la construcción de una memoria que transforme a las personas afectadas por la victimización en sus territorios.

Las medidas de no repetición fueron diseñadas para lograr un diálogo directo con instituciones como la Fiscalía General de la Nación. La construcción de protocolos y metodologías de reconciliación y convivencia desde los territorios con todos los actores del conflicto armado para la prevención y la protección individual y colectiva de los derechos a la vida e integridad personal y la formulación de planes de prevención territorial con la reactivación de la organización.

Las medidas de rehabilitación, igualmente, fueron diseñadas en la vía de la construcción de planes de prevención territorial para la reactivación de la organización, la reconstrucción del tejido social y el diseño de estrategias de autocuidado.

De la información obtenida, es evidente que las medidas a pesar de ser eficaces, pertinentes y concertadas no han sido oportunas en su implementación. Por tanto, la organización en 
conjunto con otros sujetos nacionales y territoriales de reparación colectiva presentaron al Gobierno Nacional un conjunto de iniciativas de reforma a la Ley 1448 de 2011 para la cabal aplicación de la reparación colectiva.

Un elemento importante a desatacar, como se anotó en los párrafos anteriores, es el hecho que el PRIC es fruto de la concertación y el consenso entre el Gobierno representado en la Unidad de Víctimas y la organización, como acción reparadora en sí misma.

En el marco de la Ley 1448 de 2011 se creó por parte de la UARIV la denominada estrategia de casos nacionales con el fin de implementar procesos de reparación integral con enfoque político y dimensión colectiva, a grupos y organizaciones sociales y políticas altamente victimizados en el marco del conflicto armado interno y contribuir al proceso de paz y a la democracia en Colombia. (UARIV, 2018) Asimismo, restablecer la capacidad de las organizaciones, comunidades y los grupos para la defensa de derechos colectivos tales como la libertad de prensa y el acceso a la información; las libertades sindicales que involucran la libertad de asociación, el derecho a la huelga y el de negociación colectiva; derechos civiles y políticos, así como derechos sociales, económicos, culturales y ambientales, que se han visto afectados por el conflicto.

Para hacer seguimiento a la estrategia mencionada, REDEPAZ lidera la coordinación de los sujetos nacionales de reparación colectiva "REPARAR"45, la cual consiste en un espacio de

\footnotetext{
${ }^{45}$ Conformada por (Centrales obreras CGT-CUT-CTC-FECODE); Periodistas; Instituto Popular de Capacitación -IPC; Red Nacional de iniciativas Ciudadanas por la Paz y Contra la Guerra-REDEPAZ; Asociación Nacional de Usuarios Campesinos ANUC; Concejales y diputados; Asociación Nacional de Usuarios Campesinos- Unidad y Reconstrucción - ANUC-UR;
} 
convergencia para la coordinación, veeduría, incidencia política y fortalecimiento de los casos nacionales de reparación colectiva reconocidos por la Ley de Víctimas, expresa su preocupación por los reiterados incumplimientos en materia de reparación colectiva y solicitan al gobierno nacional acciones contundentes para el goce efectivo de derechos y el logro de las transformaciones sociales que en relación a las victimizaciones ocasionadas por el conflicto armado colombiano. Espacio que viene siendo acompañado por organismos internacionales y CODHES (Consultoría para los Derechos Humanos y el Desplazamiento).

La coordinación realizó un balance del programa de reparación colectiva y encontró falencias en su implementación, debido a la falta de articulación entre la UARIV y el SNARIV. Otra de las dificultades para la implementación de los planes de Reparación Colectiva ha sido la falta de un presupuesto claro y definido para los casos de RC, además de las dificultades en la contratación oportuna de los operadores logísticos, lo que ha conllevado al atraso e incumplimiento de las agendas y cronogramas acordados con las organizaciones. (Sanabria, 2014).

Entre otras problemáticas constantes y comunes señalaron la comprensión integral de la dimensión colectiva del daño implica diferenciar los impactos de los hechos individuales de los colectivos; no obstante, todos los Sujetos de Reparación Colectiva asumimos los retos propios de los procesos y participamos de una serie de reuniones con el fin de trazar la ruta de reparación, las etapas de cada proceso y los requisitos de cada una de las fases en una dinámica no siempre 
autónoma, pero en el marco de principios de voluntariedad que ratifica el ingreso al programa.

En la mayoría de los casos, no se ha logrado sentar la base de los diagnósticos del daño y planes de Reparación, la mayoría de los procesos se detuvo, dando paso a eternas revisiones y ajustes recurrentes y estados de estancamiento que alcanzan los 8 meses, entre interinidades administrativas, falta de comprensión de principios y desarrollo jurisprudenciales e internacionales sobre la materia y la dimensión colectiva de los derechos a tutelar, en muchos casos, por la falta de operador y de funcionarios comprometidos y conocedores de los procesos en cada uno de los casos.

La no culminación exitosa del alistamiento institucional en los procesos y la cada vez más evidente desarticulación entre entidades del Estado, se convierte en una suma de acciones fragmentadas que se reducen a la participación eventual de funcionarios en reuniones convocadas por entidades sin competencia o sin el suficiente poder de tomar decisiones. La situación descrita empeora cuando los encargados de ejecutar actividades de los Planes Integrales de Reparación Colectiva PIRC son actores externos que no cuentan con el conocimiento de los sujetos o los derechos a reparar.

Las dificultades presupuestales han impedido el avance de la ruta de reparación, formulación e implementación de los PIRC. El tema de los operadores logísticos se ha convertido en el medio para ejecutar y justificar dinero que no es empleado totalmente en la reparación de los sujetos o que incluso, los mismos muchas veces desconocen su inversión. A propósito, la Corte Constitucional mediante Sentencia C-753 de 2013 determinó que “el derecho a la reparación de las víctimas es 
fundamental y no puede ser limitado, negado o desconocido por razones de sostenibilidad fiscal ya que se ha considerado que este es solo un criterio orientador de las ramas del poder para conseguir los fines del Estado".

En este punto, es importante tener en cuenta el aspecto relacionado con la integralidad de la reparación. Al respecto, Beristain (2010b) indica que las medidas de reparación cuyos criterios son coherentes con el sentido y el motivo de ser de la reparación tienen un grado alto de integralidad. Esta noción se relaciona con los de jerarquía y proporcionalidad, las cual hacen referencia, respectivamente, al hecho de que las medidas de reparación realmente respondan al impacto de las violaciones y al hecho de que realmente sean proporcionales con las violaciones cometidas. Con base en lo anterior, se puede afirmar que, aunque las medidas de reparación concertadas entre el Gobierno y diferentes sujetos nacionales de reparación colectiva sean proporcionales con respecto al daño sufrido, se pierde la dimensión de jerarquía en la ejecución de las mismas y, así, pierden integralidad.

Lo anterior ha ocasionado que a la fecha ninguno de los 617 casos de Reparación Colectiva reconocidos mediante resolución e incluidos en el Registro Nacional de Víctimas, con presencia en todo el territorio Nacional ha finalizado con éxito su ruta de reparación, entre otras razones porque se ha priorizado la reparación individual sobre la colectiva aun cuando es esta la que busca fortalecer y recuperar el tejido social y de los procesos colectivos territoriales y nacionales (Sanabria, 2014, p.33).

Durante el tercer encuentro de la Coordinación Nacional de Sujetos de Reparación Colectiva que tuvo lugar en la ciudad de Santa Marta, los asistentes diseñaron un sistema de seguimiento y 
veeduría a la implementación de los planes de reparación colectiva, este sistema se suma a los esfuerzos de la coordinación por fortalecer los procesos. Para el diseño de este sistema, se trazó una ruta de instalación de la veeduría que consta de cuatro pasos: el primero, realizar una identificación de los miembros y el estado de su proceso de reparación; el segundo, consiste en generar un espacio de capacitación y asesoría para aquellos que conformen la veeduría, gestionado con la Red Nacional de Veedurías; el tercero, se llevará a cabo la inscripción ante la Procuraduría General de la Nación y; por último, se buscará hacer la vinculación oficial al Observatorio de Reparación Colectiva. (Sanabria, 2015).

Este grupo de coordinación trazó una estrategia para los sujetos de reparación colectiva con el fin de asegurar la incidencia e interlocución con la unidad de víctimas para la implementación efectiva de lo establecido en el 5.1.3.3.3 del acuerdo de paz firmado entre el gobierno y las FARC, en lo referente a los planes nacionales de reparación colectiva (Sanabria, 2017 b).

El Cuarto Informe de la Comisión de seguimiento del Congreso de la República a las Leyes 1448 de 2011 y 975 de 2005 respecto a la reparación colectiva de los sujetos nacionales señalo:

En el PIRC de cada sujeto de reparación colectiva, fueron aprobadas un número de medidas de la siguiente forma: REDEPAZ (15), ANUC (12), IPC (11), y Concejales y Diputados (7). Cada una de estas medidas cuenta con acciones que están siendo implementadas, otras se encuentran en gestión y otras ya se implementaron. Desde ahí, se tiene que IPC y Concejales y Diputados no tienen ninguna acción implementada, mientras que REDEPAZ ha implementado el $6.81 \%$ de sus acciones y ANUC ha 
implementado el 5.12\%. [...] Así las cosas, el avance en la implementación de las medidas de los casos nacionales de reparación colectiva con incidencia nacional es preocupante. El primer plan aprobado fue el de IPC el 27 de julio de 2015, seguido por REDEPAZ el 29 de septiembre del mismo año, ANUC el 18 de marzo de 2016, y Concejales y Diputados el 5 de abril de 2016. [...] Por su parte REDEPAZ ha avanzado en 3 acciones en 21 meses. Se observa que la implementación del plan de IPC no ha avanzado de la misma manera, si se tiene en cuenta que lleva casi dos años en implementación y ninguna medida se reporta como implementada. Respecto de Concejales y Diputados en 14 meses ninguna acción se ha implementado (Comisión de Seguimiento y Monitoreo a la implementación de la ley 1448 de 2011, 2018, p.169).

Ante la falta de eficiencia por parte del Estado y en particular de la Unidad de Víctimas como organismo coordinador del sistema en la implementación de la reparación colectiva tanto de REDEPAZ como de diferentes sujetos nacionales y territoriales de reparación colectiva solicitaron al gobierno nacional una modificación estructural a la Ley 1448 y sus Decretos reglamentarios, respecto a la implementación de las reparaciones colectivas, mediante iniciativas como la generación de diálogo directo entre los máximos responsables del Estado y los representantes de las organizaciones de los sujetos de reparación colectiva, la dotación de recursos financieros suficientes, mecanismos de coordinación interinstitucional, entre otras.

A pesar de los incumplimientos del Gobierno entorno a la reparación colectiva, REDEPAZ ha logrado, por su propia iniciativa, las medidas de reparación adoptadas hasta ahora y el clima político producto de los acuerdos de paz la reactivación de la organización, su reposicionamiento 
político y su redimensionamiento como sujeto con identidad propia, permitiéndole llegar a espacios de representación como el Consejo Nacional de Paz, el cual fue convocado nuevamente gracias al acuerdo final suscrito entre el Gobierno Nacional y las FARC - EP.

Finalmente, hay que anotar que existen múltiples retos para la organización, especialmente, respecto a las medidas de no repetición, toda vez que el Conflicto Armado Interno no ha cesado y persisten antiguas estructuras guerrilleras en las regiones donde opera la organización, así como el surgimiento de estructuras nuevas como las Bandas Criminales Emergentes, que le disputan el monopolio de la fuerza legítima al Estado con el fin de mantener el control territorial, social, político y militar en los territorios antiguamente controlados por los paramilitares y aquellos dejados por las FARC - EP , mediante el uso de la violencia y las violaciones sistemáticas de los derechos humanos de los pobladores y organizaciones que luchan por la paz, la reconciliación y la convivencia pacífica. 


\section{Conclusiones y Recomendaciones}

\subsection{Conclusiones}

La Ley 1448 de 2011 estructuró un conjunto de instrumentos, instituciones, mecanismos y medidas de reparación acorde con los estándares internacionales de derechos humanos y de las experiencias de países en procesos de transicionalidad, como un esfuerzo del Estado por poner a las víctimas como el centro del camino hacia la paz y la reconciliación.

La Red Nacional de Iniciativas en Contra de la Guerra y a Favor de la Paz es una organización de carácter nacional y territorial reconocida como sujeto nacional de reparación colectiva, debido a las múltiples violaciones de los derechos humanos de sus miembros.

La organización emerge como una respuesta de la sociedad colombiana a la necesidad de buscar salidas a la guerra y a la construcción de la paz a través de los procesos de negociación. Está estructurada por organizaciones y personas en todo el territorio nacional, que han sido seriamente afectadas por los procesos de victimización.

El conjunto de medidas de reparación colectiva está estructurado con base en los estándares internacionales y nacionales de derechos humanos, bajo cuatro modalidades de reparación: restitución, rehabilitación, satisfacción y no repetición. REDEPAZ asume la reparación colectiva desde un enfoque basado en la corresponsabilidad, en la medida que amplía la categoría de víctima a la de ciudadanos activos con goce de derechos, con lo que se supera el estigma de 
víctima como receptor de 'caridad' y de reparación limitada a la vía administrativa.

Las medidas de reparación se encuentran orientadas básicamente a la recuperación de sus estructuras políticas internas y externas, a ampliar sus posibilidades de acción política, incidencia nacional y territorial y el empoderamiento de sus miembros y colectividades territoriales. Al tener el enfoque del empoderamiento del sujeto como centro y protagonista de su propio proceso de reparación, promueve más y mejores formas de participación y acción ciudadana para el desarrollo sostenible y la reconciliación.

El empoderamiento político del Comité de Impulso del proceso de Reparación Colectiva de REDEPAZ crea más y mejores oportunidades de participación e incidencia en la implementación de los planes de reparación, así como en la gestión pública en los territorios.

Las medidas de reparación buscan el fortalecimiento desde la reconstrucción de la memoria, a través de los diferentes mecanismos arriba señalados, con la particularidad de que adopta un enfoque novedoso desde la práctica internacional y nacional en materia de justicia transicional, la denominada memoria transformadora.

Esta noción de memoria transformadora, al enfocarse en la reconstrucción de la memoria, no como una simple evocación de violaciones del pasado, sino en la transformación de las víctimas con proyección hacia el futuro, es un insumo valioso para otros procesos de reparación colectiva en el país. En sí misma, la memoria transformadora es digna de estudio académico; sin embargo, más allá de eso, se puede considerar susceptible de introducirse en el tejido de otros procesos de 
sujetos nacionales de reparación colectiva.

En conjunto, las medidas de reparación tienen un enfoque en la prevención de futuras vulneraciones a los derechos de sus miembros y la organización, así como en la protección de sus miembros a través de diferentes dispositivos que sistémicamente contribuyan a su fortalecimiento organizativo y político. Para garantizar la reparación de violaciones de derechos humanos en víctimas colectivas, estas medidas pueden ser adoptadas y modificadas de acuerdo con la situación particular de cada sujeto.

La reparación colectiva de REDEPAZ aborda un enfoque diferencial y de derechos humanos acorde con las diversidades y particularidades de la población para responder desde la reparación colectiva, de forma integral y con plena garantía de derechos.

En su proceso de reparación colectiva integral, REDEPAZ realizó un cambio organizativo con enfoque de género y de derechos humanos para rescatar la dignidad y la igualdad de las mujeres y fomentar contextos que no darán continuidad a la desigualdad de género.

Es evidente con la información recolectada, la eficacia y pertinencia de las diferentes medidas adoptadas, pero su incipiente implementación demuestra la poca eficiencia del Estado y la escasa voluntad política en el goce efectivo de los derechos de las víctimas y de la organización misma como entidad propia.

Es destacable que el propio proceso político puesto en marcha con la negociación del 
Gobierno con las FARC - EP le ha permitido a la organización seguir delante de su proceso de reorganización, reestructuración e incidencia política, tanto así que, ocupa un lugar destacable ante el Consejo Nacional de Paz por consenso de las organizaciones de la sociedad civil que hace parte de este, lo que implica a su vez nuevos retos por la eficiente mutación de nuevas formas de criminalidad en los territorios en los que hace presencia la organización ante la falta de presencia del Estado. A pesar de estos avances logrados por voluntad propia, para cumplir a cabalidad el proceso de reparación, las medidas del Estado deben componerse con mayor integralidad y demostrar mayor voluntad y sentido de cooperación con la organización en cuestión y con otros sujetos nacionales de reparación colectiva.

La integralidad de la reparación enmarcada en la Ley 1448 (2011), se da no porque abarca componentes tradicionales de la reparación judicial, como las indemnizaciones y los elementos materiales, sino porque involucra aspectos inmateriales orientados al restablecimiento del goce de los derechos de las víctimas y a la reorientación del proyecto de vida, en este caso colectivo, y como ya se dijo, al valor de la ciudadanía como agente activo de la sociedad y de la paz. Esta reparación también se muestra proporcional con las violaciones cometidas en el pasado. Esta integralidad se pierde, sin embargo, en el incumplimiento de los procesos por parte del Gobierno nacional, pese a que la reparación sea proporcional con las violaciones sufridas. Esto también demuestra una falta de la dimensión de jerarquía en las medidas del Estado colombiano.

La investigación corrobora la precaria información con que cuenta la organización para la sistematización y evaluación de cada una de las medidas propuestas. Como se anotó, la información es precaria, parcial, fragmentada y adolece de posibilidades de análisis en su 
conjunto. Por ello, se requiere una documentación más amplia para lograr realizar un análisis más profundo.

A la fecha, no se cuenta con elementos suficientes, de tal manera que sea posible inferir la verdad de los hechos ocurridos de violación de los derechos humanos, tanto en sus aspectos individuales como colectivos de la organización. Muy a pesar de que se estableció el daño en el Plan Integral de Reparación Colectiva, aún no se han esclarecido los hechos individuales y colectivos.

Uno de los elementos esenciales para el goce efectivo del ejercicio de la justicia, la reparación y la no repetición está presente en la investigación y el juzgamiento de sus responsables. Del análisis de la búsqueda, se infiere que uno de los aspectos de la reparación no se ha cumplido y es el relativo a las relaciones de la organización con la Fiscalía General de la Nación.

Si bien es cierto que REDEPAZ, con el apoyo de la UARIV y de la Universidad Javeriana, construyó una fundamentación innovadora sobre lo que se denomina "Memoria Transformadora", en la información recopilada y sistematizada no se evidencian ejercicios efectivos, individuales o colectivos de construcción o reconstrucción de la memoria histórica. Es imperativo, sin embargo, insistir en estos ejercicios. El potencial de la memoria transformadora presenta una serie de aspectos que, en el proceso de reconstrucción de la memoria y el refortalecimiento organizativo, pueden resultar positivos. 
Por otro lado, la falta de mecanismos extrajudiciales de investigación no ha permitido establecer la verdad de los hechos individuales o colectivos sobre violaciones de los derechos humanos. La investigación estableció como objetivo la construcción del estado del arte de la reparación colectiva, si bien se logró reconstruir en gran medida el proceso desarrollado por la organización y el Estado, el marco legal, institucional y las medidas adoptadas se adolece de información suministrada por las entidades competentes frente a su grado de cumplimiento, se logró obtener información fragmentada de la implementación de las medidas, pero es insuficiente para realizar un examen objetivo del proceso.

Por lo anterior, aunque el presente trabajo no constituye un análisis plenamente exhaustivo de REDEPAZ, puede ser un insumo importante para el estudio posterior de otros sujetos nacionales de reparación colectiva y, además de esto, para la planificación, la evaluación y la concreción de otros Planes Integrales de Reparación Colectiva que vayan surgiendo. Es decir, más allá de los trabajos académicos, este tipo de estudios pueden ser de beneficio para las mismas organizaciones, grupo sociales y asociaciones que se agrupen alrededor de la figura legal del sujeto de reparación colectiva.

\subsection{Recomendaciones}

Con la poca información que se dispone se puede observar que las reparaciones colectivas no han sido una prioridad para el Gobierno Nacional, esta situación es evidente en el caso específico de REDEPAZ. Para que la reparación colectiva en el caso que nos ocupa como la de 
otros sujetos nacionales sea efectiva se requieren una serie de cambios estructurales de la Ley 1448 de 2011 para ello se recomienda:

Establecer una Mesa Nacional de Víctimas de Sujetos de Reparación Colectiva independiente a la Mesa Nacional de Víctimas, con el fin de garantizar su participación en el diseño, implementación, ejecución y evaluación de las políticas de reparación.

Esta Mesa debe contar con mecanismos de interlocución del más alto nivel posible con el Gobierno Nacional con el fin de garantizar una efectiva y eficiente aplicación del marco normativo diseñado para la reparación colectiva de los sujetos nacionales y territoriales.

Entre los mecanismos a adoptar se debe contar con reuniones periódicas con el Comité Ejecutivo para la Atención y Reparación de las Víctimas, con la finalidad de hacer seguimiento, monitoreo y fortalecimiento de los Planes Integrales de Reparación Colectiva de los Sujetos Nacionales de Reparación Colectiva.

Se debe crear una Comisión de Seguimiento y Monitoreo, la cual tendrá como función primordial hacer seguimiento al proceso de diseño, implementación, ejecución y cumplimiento de las medidas contenidas en la ley, por representantes del más alto nivel del de los organismos de control del Estado en coordinación con los sujetos nacionales de reparación colectiva.

Establecer dentro del Fondo de Reparación para las Víctimas de la Violencia una subcuenta o rubro destinado exclusivamente para la financiación de los Planes Integrales de Reparación 
Colectiva de los Sujetos Nacionales de Reparación Colectiva, ejecutados conforme a las reglas de derecho privado, sin perjuicio de los principios generales de la administración pública. La ejecución o administración de los recursos destinados para los Planes Integrales de Reparación Colectiva en las diferentes etapas de la ruta administrativa de los sujetos nacionales de reparación colectiva podrá estar a cargo de los mismos sujetos de reparación colectiva.

Expedición de un documento CONPES con una política nacional de reparación colectiva, procurando la participación de las distintas entidades de la administración pública con obligaciones en las materias específicas y misionales a que haga referencia cada medida susceptible de ser establecida en la política, con el objetivo de garantizar su ejecución coordinada e inmediata o en un plazo razonable. El documento CONPES deberá contener unos antecedentes, la caracterización de las víctimas sujetos nacionales de reparación colectiva, incluyendo el enfoque diferencial como sujetos de derechos políticos, modalidades de reparación (reconocimiento, simbólica y económica), planes integrales de reparación colectiva, y sistema de seguimiento y monitoreo.

Es necesario generar mayor consciencia acerca del estado de los procesos de reparación colectiva en el país. Esto se puede lograr por medio del estudio y del análisis académico de estos procesos; sin embargo, para ello, es importante una mayor visibilización de estos sujetos. En últimas, son estos los que solicitan y necesitan una mayor veeduría y escrutinio del Estado en todos estos procesos. Esto es especialmente imperativo, ya que el conflicto armado interno aún no termina; aún hay actores que cometen actos ilícitos a lo ancho del territorio y, por lo tanto, víctimas de estos actos que requieren garantías de reparación. El diagnóstico y la formulación de 
la política pública alrededor de esta problemática requiere amplia documentación acerca de las víctimas, sin comprometer nunca su integridad ni incurriendo en nuevas violaciones de sus derechos.

Por ello, se espera que los estudios que se puedan basar sobre este trabajo busquen siempre el impacto positivo en las comunidades involucradas. 


\section{Referencias Bibliográficas}

Amnistía Internacional. (2012). Colombia: la ley de víctimas y de restitución de tierras. Bogotá.

Amnistía Internacional. (2016). Víctimas de la guerra civil y el franquismo: no hay derecho. Preocupaciones sobre el proyecto de ley de "derechos de las víctimas de la guerra civil y del franquismo". Madrid: Sección Española de Amnistía Internacional.

Arango, R. (2007). Justicia transicional y derechos en contextos de conflicto armado . En memorias del seminario: El legado de la verdad: Impacto de la justicia transicional en la construcción de la demanda en América latina. Obtenido de http://www.ictj.org/es/news/pubs/

Beristain, C. (2010a). Diálogos sobre la Reparación. Que reparar en los casos de violaciones de derechos humanos. San José de Costa Rica.

Beristain, C.M. (2010b). Manual sobre perspectiva psicosocial en la investigación en derechos humanos. Bilbao: Hegoa.

Cesti, P. (2001). Corte I.D.H. (ser. C) No. 78, 35-37 . Praguay.

Comisión de Seguimiento y Monitoreo a la implementación de la ley 1448 de 2011. (2018). Cuarto Informe sobre la implementación de la Ley de Víctimas y Restitución de Tierras al Congreso de la República. Bogotá. 
Conpes 326. (2016). Política integral de atención y reparación de Víctimas. Bogotá.

Convensión Americana de Derechos Humanos . (1978). San José de Costa rica.

Correa, L. (2015). Restauración ambiental y posconflicto. Revista Universidad de La Salle, 6 (12), 133-144.

Corte Interamericana de Derechos Humanos. (2006). Caso del Penal Miguel Castro Castro Vs. Perú. Sentencia de 25 de noviembre de 2006.

Corte Penal Internacional. (1998). Estatuto de Roma. Obtenido de http://www.un.org/spanish/law/icc/statute/spanish/rome_statute(s).pdf

Crawford, J. (2009). Artículos sobre responsabilidad del Estado por hechos internacionalmente ilícitos. Recuperado en http://legal.un.org/avl/pdf/ha/rsiwa/rsiwa_s.pdf

Cuéllar, B. (2005). El Salvador: ¿Justicia transicional? ¿Impunidad tradicional? . Obtenido de Cuéllar Martínez, B. (2005). El Salvador:¿Justicia transicional? ¿Impunidad tradicional? Retrieved 20 noviembre, 2016, from https://www.ictj.org/es/our-work/transitionaljustice-issues/reparaciones 
De Greiff, P. (2008). Justicia y Reparaciones. Reparaciones para las víctimas de la violencia política. Bogotá: Centro Internacional para la Justicia Transicional.

Decreto 4800. (2011). Por el cual se reglamenta la Ley 1448 de 2011 y se dictan otras disposiciones. Bogotá: Congreso de la República.

Díaz , Bastien, Vargas \& Zúñiga. (2014). El acceso al sistema interamericano de derechos humanos. Madrid - España: Editorial Reus .

Durán, P. (1993). Manual de Derechos Humanos. Barcelona: Editorial Comares.

FIP. (2014). Fondo Ideas Para la Paz. Boletín de Paz No. 35 - Negociaciones de paz - Agosto 2014. Derecho de las Víctimas. Obtenido de http://cdn.ideaspaz.org/media/website/document/540780d4edc63.pdf

Garcia, L. (1976). ¿Qué es un dispositivo? Buenos Aires: Trillas editores.

Gómez, I. (2008). El fenómeno de la impunidad: luces y sombras en América Latina. Revista Pensamiento iberoamericano(, 8 (2), 163-185.

González Chavarría, A. (2010). Justicia transicional y reparación a las víctimas en Colombia. Revista mexicana de sociología, 72(4), 629-658. 
Henckaerts, J \& Doswald, L . (2005). Customary international humanitarian law [derecho internacional humanitiario consuetudinario] . Barcelona: Mc Graw Hill.

ICTJ. (2015). Centro Internacional para la Justicia Transicional. Centro Internacional de Justicia Transicional. Bogotá.

ICTJ. (2016). Centro Internacional para la Justicia Transicional. Reparaciones. Obtenido de https://www.ictj.org/es/our-work/transitional-justice-issues/reparaciones

Iepala. (2017). Instituto de Estudios Politicos para America Latina y Africa. Obtenido de www. Iepala.es/DDDD/ddhh33.htm

Instituto Interamericano de Derechos Humanos. (20011). Contribución de las políticas de verdad, justicia y reparación a las democracias en América Latina. San José, C.R. : IIDH

Joinet, M. (1997). Conjunto de Principios para la lucha contra la impunidad, en La cuestión de la impunidad de los autores de violaciones de los derechos humanos civiles y políticos. Aplicación de la decisión 1996/119 de la Subcomisión. Buenos Aires.

Jouannet, E. (2011). ¿ De qué sirve el derecho internacional? El derecho internacional providencia del siglo XXI. Revista de Derecho Público, 12 (9) 12-16. 
Ley 1448. (2011). Por la cual se dictan medidas de atención, asistencia y reparación integral a las víctimas del conflicto armado interno y se dictan otras disposiciones. Bogotá: Congreso de la República.

Ley 446. (1998). Por lo cual se adoptan como legislación permanente algunas normas del Decreto 2651 de 1991, se modifican algunas del Código de Procedimiento Civil, se derogan otras de la Ley 23 de 1991 y del Decreto 2279 de 1989. Bogotá: Congreso de la República de Colombia .

Ley 472. (1998). Por la cual se desarrolla el artículo 88 de la Constitución Política de Colombia en relación con el ejercicio de las acciones populares y de grupo y se dictan otras disposiciones. Bogotá: Congreso de la República .

Ley 975. (2005). Por la cual se dictan disposiciones para la reincorporación de miembros de grupos armados organizados al margen de la ley, que contribuyan de manera efectiva a la consecución de la paz nacional y se dictan otras disposiciones para acuerdos humanitarios. Bogotá: Congreso de la República.

Lira, E. (2011). Verdad, reparación y justicia: el pasado que sigue vivo en el presente. Obtenido de https://www.ictj.org/es/our-work/transitional-justice-issues/reparaciones 
López, J \& Acosta, J. (2009). Asistencia estatal a los desplazados y reparaciones en el Sistema Interamericano de Derechos Humanos. Red International Law. Revista Colombiana de Derecho, 2 (12) 122-146.

Martín, P . (2007). Derechos humanos, modelos de desarrollo y políticas de transición, Memorias -Conference Paper 3, "Dealing with the Past", Serie - Enfrentando el pasado; El legado de la verdad.

Mesa, R. (2016). Integrante del Comité de Impulso. Bogotá: Redepaz.

Ministerio del Interior. (2016). Guía práctica de reparación colectiva para los comités territoriales de Justicia Transicional. Bogotá: El Ministerio.

Muro, A. (2013). ¿Qué es y cómo funciona la Corte Interamericana de Derechos Humanos? En: https://eljuegodelacorte.nexos.com.mx/?p=3230

Naciones Unidas. (2014). Derechos Humanos. Justicia transicional y derechos económicos, sociales y culturales. Nueva York .

Naciones Unidas. (2015). Informe de Diane Orentlicher, experta independiente encargada de actualizar el conjunto de principios para la lucha contra la impunidad. 
Newman Pont, V. (2009). Falso o verdadero (i El derecho a la verdad es norma imperativa internacional?). . International Law(, (14), 43-69.

Núñez, R \& Zuluaga, L. (2012). Estándares internacionales de reparación de violaciones de derechos humanos:principios de implementación en el derecho colombiano. Obtenido de https://revistas.utadeo.edu.co/index.php/RAI/article/viewFile/853/864

OHCHR. (2014). Oficina del Alto Comisionado para los Derechos Humanos. Reparaciones por la violencia sexual relacionada con los conflictos. Obtenido de http://www.ohchr.org/Documents/Issues/Women/WRGS/PeaceAndSecurity/Reparations ForCRSV_sp.pdf

Oficina del Alto Comisionado para las Naciones Unidas para los Derechos Humanos. (2008). Instrumentos del estado de derecho para sociedades que han salido de un conflicto. Programas de reparaciones. Nueva York y Ginebra: Naciones Unidas.

ONU. (1985). Organización de las Naciones Unidas. Resolución 40/34. Declaración sobre los principios fundamentales de justicia para las Víctimas de delitos y del abuso de poder. Obtenido de http://www.un.org/es/comun/docs/?symbol=A/RES/40/34\&Lang=S

Orentlicher. (2005). Conjunto de principios para la protección y la promoción de los derechos humanos mediante la lucha contra la impunidad. Viena: Conferencia Mundial de Derechos Humanos . 
Ospina, J. (2007). Memorias - Conference Paper 3, "Dealing with the Past”, Serie - Enfrentando el pasado; El legado de la verdad.

Pérez-León, J. (1 de septiembre de 2008). Las reparaciones en el derecho internacional de los derechos humanos, derecho internacional humanitario y derecho penal internacional. Recuperado de http://www.corteidh.or.cr/tablas/R22048.pdf

Pérez Luño, E. (2006). La tercera generación de derechos humanos. Buenos Aires: Editorial Aranzadi.

Redepaz. (1993). Red Nacional de Iniciativas Ciudadanas por la Paz y contra la Guerra. Acta de constitución. Bogotá.

Redepaz. (2013). Red Nacional de Iniciativas Ciudadanas por la Paz y contra la Guerra. Plan Integral de Reparación Coletiva. Bogotá.

Redepaz. (2014 a). Red Nacional de Iniciativas Ciudadanas por la Paz y Contra la Guerra. Estatutos Corporación para la Paz y los Derechos Humanos. Bogotá.

Redepaz. (2014 b). Red Nacional de Iniciativas Ciudadanas por la Paz y Contra la Guerra. Resiliencia colectiva, reconstrucción de sueños colectivos y reconciliación. Bogotá. 
Redepaz. (2014). Red Nacional de Iniciativas Ciudadanas por la Paz y contra la Guerra. Área de consenso ciudadano por la paz. Obtenido de http://www.redepaz.org.co/index.php/shortcode/conseso-ciudadano-por-la-paz

Redepaz. (2014). Red Nacional de Iniciativas Ciudadanas por la Paz y contra la Guerra. Documento en Construcción. Unidad de Atención y Reparación Integral a las Víctimas. Bogotá: Redepaz y Universidad Javeriana.

Redepaz. (2015). Red Nacional de Iniciativas Ciudadanas por la Paz y Contra la Guerra. Informe de Gestión. Bogotá.

Redepaz. (2016 a). Red Nacional de Iniciativas Ciudadanas por la Paz y Contra la Guerra. Obtenido de http://www.redepaz.org.co/

Redepaz. (2016 b). Red Nacional de Iniciativas Ciudadanas por la Paz y contra la Guerra. Informe Evento Comité de Impulso Proceso de Reparación Colectiva. . Medellín.

Redepaz. (2016 c). Red Nacional de Iniciativas Ciudadanas por la Paz y Contra la Guerra. Informe de Gestión. Bogotá.

Redepaz. (2017 a). Red Nacional de Iniciativas Ciudadanas por la Paz y Contra la Guerra. Informe General Semanas por las Paz 2017. Documento elaborado como parte del 
acuerdo de voluntades suscrito entre la Unidad de Atención y Reparación Integral a Víctimas. Bogotá.

Redepaz. (2017 b). Red Nacional de Iniciativas Ciudadanas por la Paz y Contra la Guerra. Ficha de Proceso de Gestión de Asistencia y Reparación Colectiva. Bogotá.

Redepaz. (2017 c). Red Nacional de Iniciativas Ciudadanas por la Paz y Contra la Guerra. Propuesta conceptual alrededor de la construcción del concepto de memoria transformadora en el marco del plan de reparación del Sujeto Colectivo. Bogotá.

Redepaz. (2017 d). Red Nacional de Iniciativas Ciudadanas por la Paz y contra la Guerra. Memorias de los encuentros regionales y asambleas. Bogotá.

Redepaz. (2017 e). Red Nacional de Iniciativas Ciudadanas por la Paz y Contra la Guerra. Informe del evento territorialidad para la Paz. Bogotá.

Redepaz. (2017 f). Red Nacional de Iniciativas Ciudadanas por la Paz y Contra la Guerra. Memorias del evento Mujeres. Bogotá.

Redepaz. (2017 g). Red Nacional de Iniciativas Ciudadanas por la Paz y Contra la Guerra. Informe de resultados del evento Trabajo con Jóvenes Constructores de Paz. Bogotá. 
Redepaz. (2017 h). Red Nacional de Iniciativas Ciudadanas por la Paz y Contra la Guerra. Informe final experiencias de trabajo con niños y niñas por la Paz. Bogotá.

Redepaz. (2017 i). Red Nacional de Iniciativas Ciudadanas por la Paz y Contra la Guerra. Informe Preliminar - Asamblea Nacional de Redepaz . 4 de diciembre de 2017 . Bogotá.

Redepaz. (2017 j). Red Nacional de Iniciativas Ciudadanas por la Paz y Contra la Guerra. Informe Memoria Transformadora. Bogotá.

Rodríguez, V. (2007). Anuario del derecho Internacional . Bogotá: Norma editores.

Rubiano, W. (2010). Aspectos sobre justicia transicional y restaurativa para la comprensión del actual proceso de paz. En Revista Temas.

Sanabria, E. (2014). La Reparación Colectiva y el Desarrollo Local. Perspectiva para la Construcción de Paz. Bogotá.

Sanabria, E. (2017 a). Informe parcial victimización. Bogotá: Redepaz.

Sanabria, E. (2015). Seguimiento veeduría a la implementación de los planes nacionales de reparación colectiva. Bogotá. 
Sanabria, E. (2017 b). Estrategia de incidencia e interlocución con la unidad de víctimas para la implementación efectiva de lo establecido en el punto 5.1.3.3.3 del acuerdo de paz firmado entre el gobierno y las farc, en lo referente a los planes nacionales. Bogotá.

Sentencia C-965. (2003). Demanda de inconstitucionalidad contra el artículo 16 de la Ley 446 de 1998, el artículo 177 del Código Contencioso Administrativo, el artículo 19 de la Ley 678 de 2001 y los artículos 4o, 5o, 14 y 27 de la Ley 80 de 1993, M.P. Rodrigo Escobar Gil. Bogotá: Corte Constitucional .

SNARIV. (2016). Sistema Nacional de Atención y Reparación integral a las Víctimas. Obtenido de http://www.unidadVíctimas.gov.co/es/gestion-interinstitucional/sistema-nacional-deatencion-y-reparacion-integral-las-Víctimas/77

Suárez, R. (1999). Corte I.D.H. (ser. C) No. 44, 41 . Ecuador .

UARIV. (2013 ). Unidad para la Atención y Reparación Integral a las Víctimas. Reparación Colectiva. Obtenido de http://www.unidadVíctimas.gov.co/es/\%C2\%BFqu\%C3\%A9-esla-reparaci\%C3\%B3n-colectiva/203

UARIV. (2016). Unidad para la Atención y Reparación Integral a las Víctimas. Procedimiento de reparación colectiva. $\quad$ Obtenido de https://www.unidadVíctimas.gov.co/sites/procesos_caracterizados/PROCEDIMIENTO_ DE_REPARACION_COLECTIVA_V1.pdf 
UARIV. (2017). Unidad para la Atención y Reparación Integral a las Víctimas. Sistema nacional de atención y reparación integral a las víctimas. Obtenido de http://www.unidadVíctimas.gov.co/es/gestion-interinstitucional/sistema-nacional-deatencion-y-reparacion-integral-lasVíctimas/77http://www.unidadVíctimas.gov.co/es/gestion-interinstitucional/sistemanacional-de-atencion-y-reparacion-integral-las-Víctimas

UARIV. (2018). Unidad para la Atención y Reparación Integral a las Víctimas. Casos nacionales. Obtenido de http://www.unidadVíctimas.gov.co/es/casos-nacionales/391

Valencia, G. \& Mejía, C. (2010). Ley de Justicia y Paz. Un balance de su primer lustro. En Perfil de coyuntura econónomica. $\mathrm{N}^{\circ} 15$. (pp. 59-77).

Valencia, V. (2008). Introducción a la justicia transicional. Claves de razón práctica. Bogotá: Norma.

Vargas, A . (2006). Corte Interamericana de Derechos Humanos [Corte I.D.H.] (ser.C) No. 155, 139. Paraguay.

Ventura, M. (2002). Impacto de las reparaciones ordenadas por la Corte Interamericana de Derechos Humanos y aportes a la justiciablidad de los derechos económicos sociales y culturales. Bogotá: panamericana editores. 
Villa, J ; Londoño, D \& Barrerra, D . (2014). Reparación a las víctimas de dictaduras, conflictos armados y violencia política. El Ágora USB, 14(2), 339-375.

Villarraga, A. (2015). Biblioteca de la Paz 19080 - 2013. Los Procesos de Paz en Colombia, 1982 - 2014. Bogotá: Gente Nueva Editorial. 